\title{
Data Requirements and Test System Needs for Development of an Integrated Off-Gas Treatment System
}

Nuclear Technology

Research and Development

\author{
Prepared for \\ U.S. Department of Energy \\ Material Recovery and Waste Form \\ Development Campaign \\ R. T. Jubin, S. H. Bruffey, J. A. Jordan, \\ B. B. Spencer \\ Oak Ridge National Laboratory \\ N. R. Soelberg, A. K. Welty and \\ M. Greenhalgh (INL) \\ $6 / 30 / 2017$ \\ NTRD-MRWFD-2017-000422 \\ ORNL/TM-2017/314
}



This report was prepared as an account of work sponsored by an agency of the United States Government. Neither the United States Government nor any agency thereof, nor any of their employees, makes any warranty, express or implied, or assumes any legal liability or responsibility for the accuracy, completeness, or usefulness of any information, apparatus, product, or process disclosed, or represents that its use would not infringe privately owned rights. Reference herein to any specific commercial product, process, or service by trade name, trademark, manufacturer, or otherwise, does not necessarily constitute or imply its endorsement, recommendation, or favoring by the United States Government or any agency thereof. The views and opinions of authors expressed herein do not necessarily state or reflect those of the United States Government or any agency thereof. 



\section{SUMMARY}

In fiscal year 2016 an Engineering Evaluation of an integrated off-gas system was conducted. This study resulted in a report entitled Engineering Evaluation of an Integrated Off-Gas Treatment System for Used Nuclear Fuel Reprocessing Facilities (Jubin et al. 2016a), from here referred to as the "Engineering Evaluation." This study focused on the capture and retention of the volatile radionuclides ${ }^{3} \mathrm{H},{ }^{14} \mathrm{C},{ }^{85} \mathrm{Kr}$, and ${ }^{129} \mathrm{I}$ ), selected semi-volatile radionuclides, specifically ${ }^{106} \mathrm{Ru}$, and chemical species like $\mathrm{NO}$ and $\mathrm{NO}_{2}$ generated during the dissolution of the used nuclear fuel. The study examined the design of the combined head-end off-gas streams and the vessel off-gas stream. The study drew upon the available literature to conduct the equipment sizing and sorbent usage. A number of assumptions were required to complete this analysis and major gaps in the available data were identified that, if resolved, could increase the fidelity of the engineering design.

This assessment looks at those identified data gaps and the more subtle assumptions that were required in the Engineering Evaluation and provides a detailed look at the specific data needs for each major system. This assessment of the data gaps builds on a study conducted early in fiscal year 2016 that established a set of performance criteria for capture and immobilization technologies. The gaps identified in the engineering assessment also provided a check on the breadth of the criteria and metrics that were previously developed. During the analysis of the data gaps it was necessary to expand the metrics slightly to capture co-adsorption effects and to address desorption, neither of which were included in the original set of metrics.

Across the six major off-gas control systems evaluated a number of common data gaps became apparent. These include:

- Capacity and adsorption rate data needs appear common for virtually all the unit operations considered. These two parameters dictate the dimensions and operating conditions of the sorbent beds and wet scrubber systems. The capacity dictates the mass and volume of $\mathrm{Ru}$, tritium, $\mathrm{I}$, and $\mathrm{Kr} / \mathrm{Xe}$ sorbent beds for a given adsorption duration; the adsorption rate dictates the needed depth of the solid sorbent beds and the height of the wet scrubbers. Co-adsorption of other species is important to the extent that this interferes with the adsorption of the target species, impacts process operation, or impacts handling, recycle, or disposal of the spent sorbent/scrub solutions, and the waste form and disposal of the captured species. This is of secondary importance compared to demonstrating and optimizing capacity and adsorption rates for the target species; but co-adsorption and impacts of coadsorption are areas where generally even less is currently known for both sorbent beds and wet scrubber systems.

- Sorbent particle and bulk densities impact the volume of the adsorption system for a given mass of sorbent, but these physical properties data are readily measured.

- For systems including regenerable sorbents, data on desorption and multicycle operations is also critical for the sizing of the subsequent recovery systems, the design of any additional purification steps, and the conversion to a waste form. In general, obtaining this type of data requires larger, more complex test beds and must be able to test the effects of co-adsorbed species. Regenerable sorbents are being tested for the separation of $\mathrm{Kr}$ and $\mathrm{Xe}$ and the removal of tritium. The scrub solution used in the $\mathrm{CO}_{2}$ scrubber is recycled back to the scrubber after precipitating out the captured $\mathrm{CO}_{2}$ and may also be considered regenerable.

Many of the data gaps identified in this report can be effectively addressed with test systems focused on specific target components. In the case of the regenerable sorbents that focus on tritium, $\mathrm{Xe}$ and $\mathrm{Kr}$, more complex test beds will be required to obtain data on the desorption behavior, co-absorbed species effects, potential product purification, and cycle time. In the case of $\mathrm{Xe}$ and $\mathrm{Kr}$ some preconditioning of the gas streams may also be required in an actual plant design. 
Data Requirements and Test System Needs for Development of an Integrated Off-Gas Treatment System

This page is intentionally left blank. 


\section{CONTENTS}

\section{SUMMARY}

FIGURES

TABLES

ACRONYMS

1. INTRODUCTION

2. APPROACH TO ASSESSING DATA GAPS

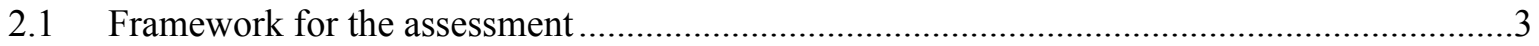

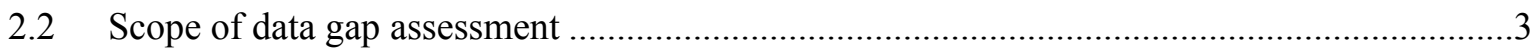

3. IDENTIFIED DATA GAPS

4. DATA GAPS

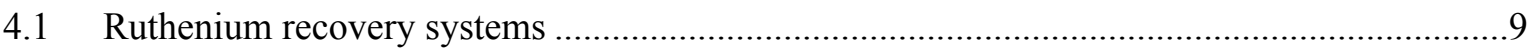

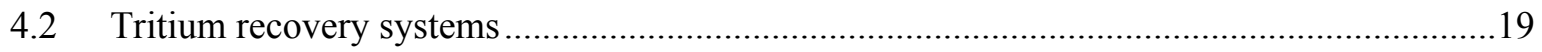

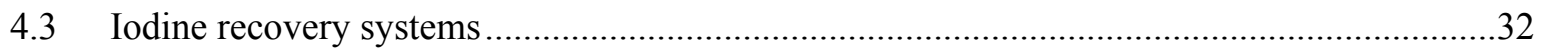

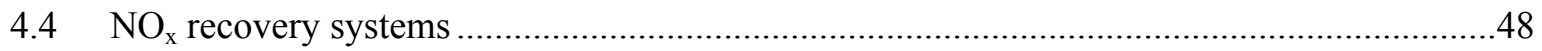

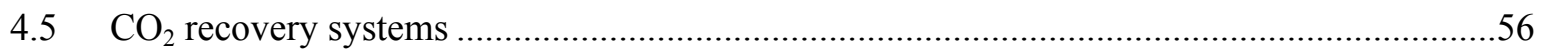

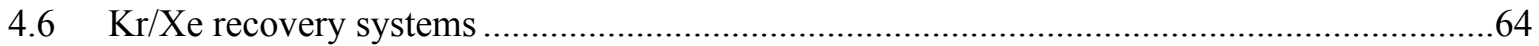

5. CONCLUSIONS AND RECOMMENDATIONS

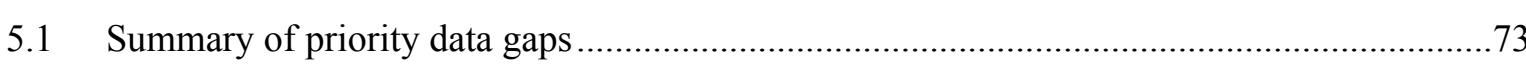

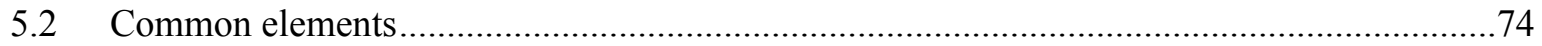

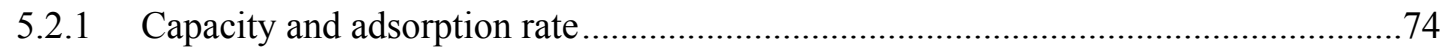

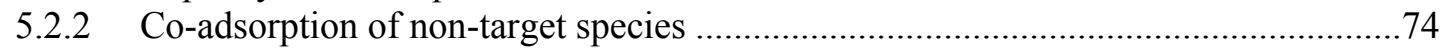

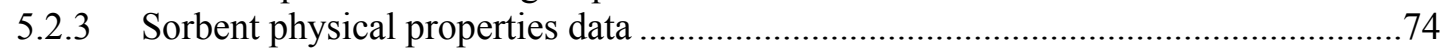

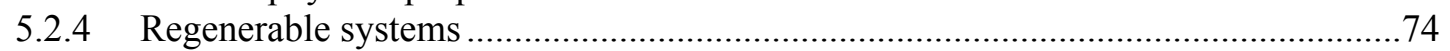

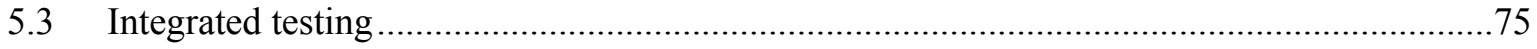

6. REFERENCES 
Data Requirements and Test System Needs for Development of an Integrated Off-Gas Treatment System 
Data Requirements and Test System Needs for Development of an Integrated Off-Gas Treatment System

This page is intentionally left blank. 


\section{FIGURES}

Figure 1. Block diagram for a dissolver off-gas treatment system (Jubin et al. 2016a). 1

Figure 2. Block diagram for a dissolver off-gas and TPT off-gas treatment system (Jubin et al. 2016a). 2

Figure 3. Block diagram for a vessel off-gas treatment system (Jubin et al. 2016a) .2

\section{TABLES}

Table 1. Capture media criteria and metrics (Jubin, et al. 2016b) .5

Table 2. Data gaps for ruthenium sorbent evaluations ..... .11

Table 3. Data needs for tritium sorbents - Air TPT case.....................................................................21

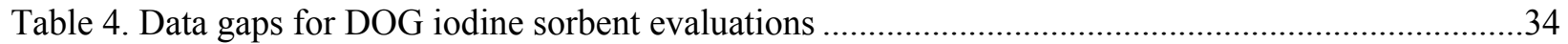

Table 5. Data gaps for iodine sorbent evaluations for air TPT and VOG gas streams ............................41

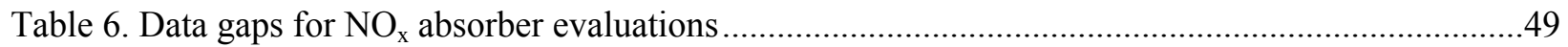

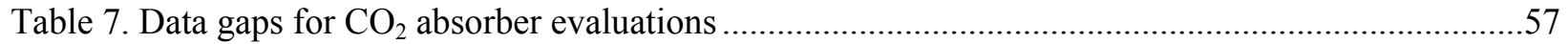

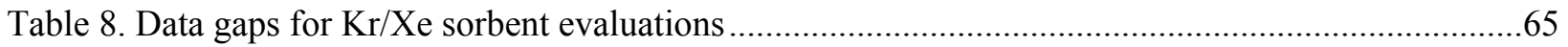


Data Requirements and Test System Needs for Development of an Integrated Off-Gas Treatment System

This page is intentionally left blank. 


\section{ACRONYMS}

$\mathrm{AgZ} \quad$ silver-exchanged mordenite (zeolite)

AgZ-PAN silver-exchanged mordenite (zeolite)-polyacrylonitrile

CETE Coupled End-to-End Research Project

DF decontamination factor

DOG dissolver off-gas

FY fiscal year

HEPA high-efficiency particulate air

HZ-PAN hydrogen mordenite (zeolite)-polyacrylonitrile

MOF metal organic framework

MS molecular sieve

MTZ mass transfer zone

ORNL Oak Ridge National Laboratory

R\&D research and development

TGA thermal gravimetric analyzer

TPT tritium pretreatment

TPTOG tritium pretreatment off-gas

VOG vessel off-gas 
Data Requirements and Test System Needs for Development of an Integrated Off-Gas Treatment System

This page is intentionally left blank. 



\section{DATA REQUIREMENTS AND TEST SYSTEM NEEDS FOR DEVELOPMENT OF AN INTEGRATED OFF-GAS TREATMENT SYSTEM}

\section{INTRODUCTION}

In fiscal year (FY) 2016 an Engineering Evaluation of an integrated off-gas system was conducted. This study resulted in a report entitled Engineering Evaluation of an Integrated Off-Gas Treatment System for Used Nuclear Fuel Reprocessing Facilities (Jubin et al. 2016a), from here referred to as the "Engineering Evaluation." This study focused on the capture and retention of the volatile radionuclides $\left({ }^{3} \mathrm{H},{ }^{14} \mathrm{C},{ }^{85} \mathrm{Kr}\right.$, and ${ }^{129} \mathrm{I}$ ), selected semi-volatile radionuclides, specifically ${ }^{106} \mathrm{Ru}$, and chemical species like $\mathrm{NO}$ and $\mathrm{NO}_{2}$ generated during the dissolution of the used nuclear fuel. The study examined the design of the combined head-end off-gas streams and the vessel off-gas (VOG) stream. The study considered two primary cases: (1) the direct dissolution of the fuel without tritium pretreatment (TPT) and (2) the use of air TPT. In the case of direct used nuclear fuel dissolution, the shear off-gas is routed to a dissolver and the resulting dissolver off-gas (DOG) stream is treated as shown in Figure 1. In the case of the air TPT, the off-gas from TPT is treated separately to recover the tritium and Ru before joining the off-gas from the dissolver between the dual condensers and the iodine recovery beds as shown in Figure 2. The VOG system is shown in Figure 3. These three figures are shown as they were originally presented in Jubin et al. 2016a and include stream numbers that will not be further discussed in this report.

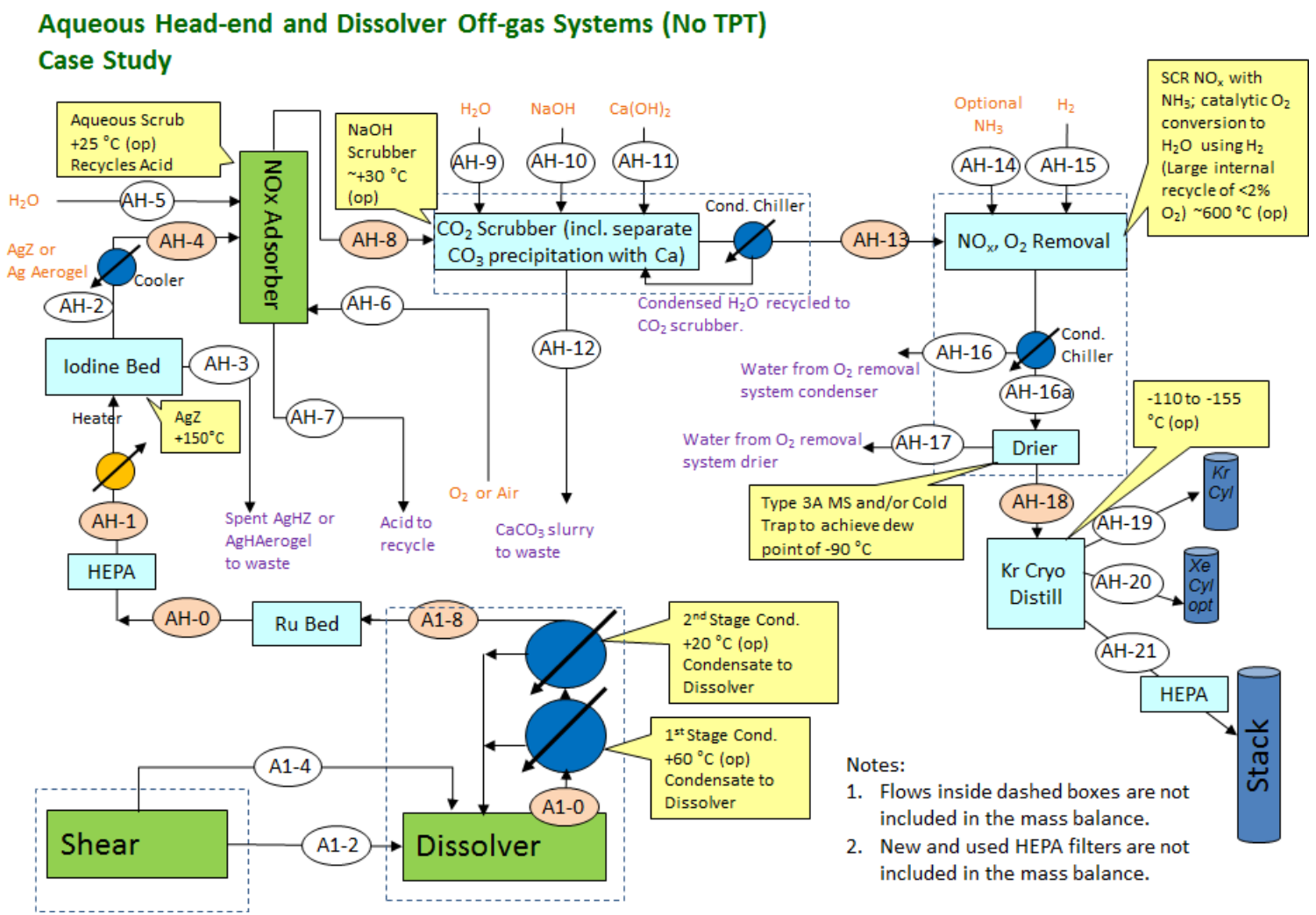

Figure 1. Block diagram for a dissolver off-gas treatment system (Jubin et al. 2016a). 


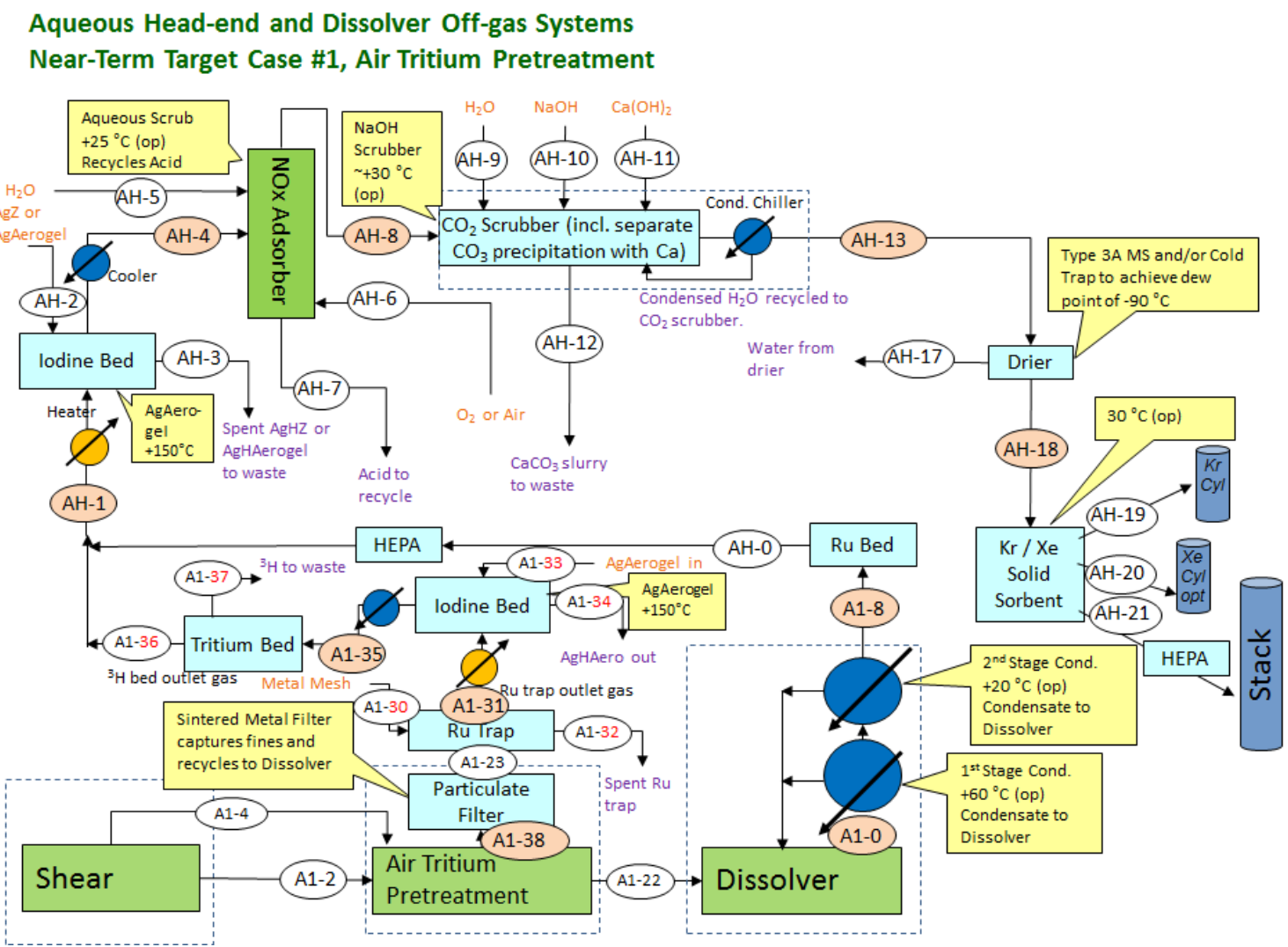

Figure 2. Block diagram for a dissolver off-gas and TPT off-gas treatment system (Jubin et al. 2016a).

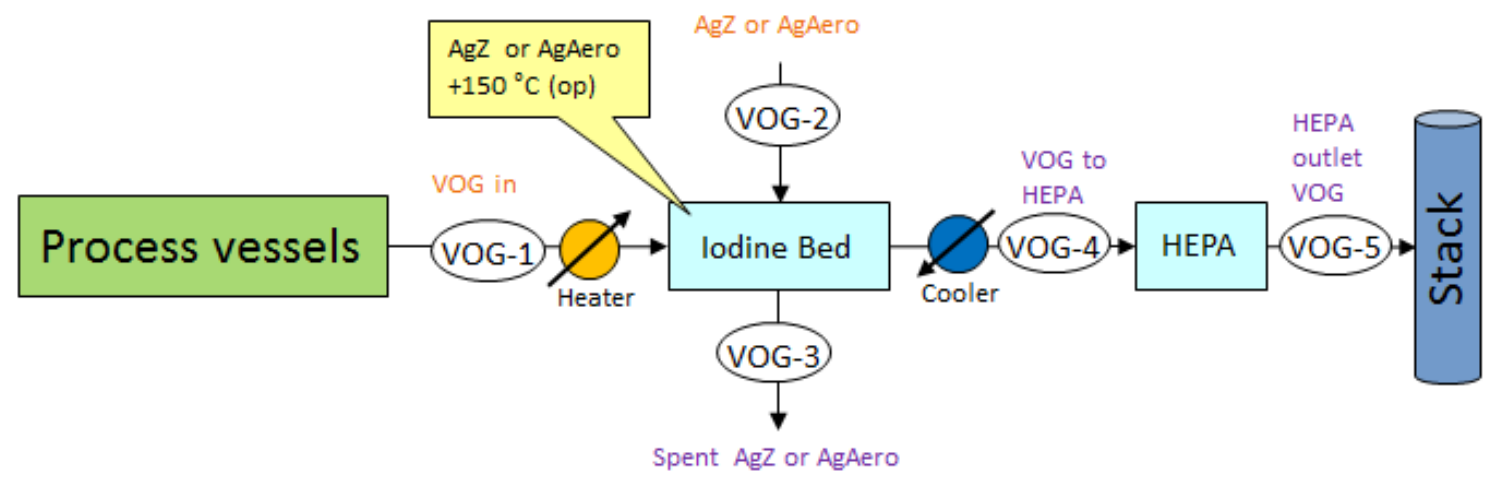

Figure 3. Block diagram for a vessel off-gas treatment system (Jubin et al. 2016a).

The study drew on the available literature to conduct the equipment sizing and sorbent usage. A number of assumptions were required to complete this analysis, and major gaps in the available data were identified that could increase the fidelity of the engineering design if resolved. This assessment looks at those identified data gaps and the more subtle assumptions required in the Engineering Evaluation, and attempts to provide a detailed overview of the specific data needs for each major system. This assessment provides a consolidated list of data needs, testing approaches, and equipment needs to close the gaps, as well as prioritizes the gaps to be closed. 


\section{APPROACH TO ASSESSING DATA GAPS}

\subsection{Framework for the assessment}

This assessment of the data gaps will build on a study conducted early in FY 2016 that established a set of performance criteria for capture and immobilization technologies (Jubin et al. 2016b). Five criteria were identified for the capture material and related systems. These were (1) technical performance and characteristics (physical and chemical properties), (2) technical practicality, (3) system design and performance, (4) technical maturity, and (5) cost. For each of these five criteria, multiple metrics were identified to describe the important aspects of that criterion. Table 1 lists the five criteria and the associated metrics. Although these criteria were developed in part to provide a technically based foundation for the comparison of sorbents, it is believed that these criteria also could be used to provide a framework for the collection and assessment of the data gaps identified in the engineering assessment. The gaps identified in the engineering assessment should also provide a means to evaluate the breadth of the previously developed criteria and metrics.

\subsection{Scope of data gap assessment}

This assessment only examines the gaps associated with the design of the off-gas treatment equipment. It is fully recognized that there are also significant gaps in relevant source terms for both the dissolver and TPT systems. These gaps should be addressed by the research and development (R\&D) efforts that are focused on the relevant processes.

\section{IDENTIFIED DATA GAPS}

During the Engineering Evaluation, a number of significant data gaps in the available information were identified. The gaps noted in the Engineering Evaluation are listed below with no importance assigned to the order (Jubin et al. 2016a):

- Pressure swing regeneration of the xenon and krypton columns-This technique appears to be viable, possibly more viable than temperature swing because of the short column change-out times required. Investigation of this technique is lacking in the current research plan.

- Face velocity values - There has been little research into what face velocities can be tolerated by the sorbents, particularly for the metal organic framework (MOF) materials.

- Mass transfer zone (MTZ) determinations-Very limited data exist on the length of the MTZ for silver-exchanged mordenite (AgZ) or Ag-Aerogel. MTZ lengths for both AgZ and Ag-Aerogel have been estimated from deep-bed tests for several years, but these estimates are limited to test durations of up to several hundred hours operation. The variation in gas flow rates, temperatures, and compositions has been limited to the scopes of those tests such as has been reported in Soelberg et al. 2013; Soelberg and Watson 2014, 2015, and 2016; and Soelberg 2016. There are few to no data on how this is impacted by gas rate and concentration. Similar measurements are lacking for the MOF materials. Testing of PAN materials has shown little velocity effect up to $6.4 \mathrm{~m} / \mathrm{min}$, but higher velocities have not been tested (Welty et al. 2016).

- $\quad$ Ruthenium decontamination factor (DF) values-An overall ruthenium DF value of $3.4 \times 10^{7}$ is needed for $5 \mathrm{y}$ cooled $60 \mathrm{GWd} / \mathrm{MTIHM}$ fuel. A review of the literature supports a DF value of about $1 \times 10^{4}$. Some uncertainties present in the literature lead to this difference. The main uncertainty is the conversion of volatile $\mathrm{RuO}_{4}$ to particulate $\mathrm{RuO}_{2}$ in the gas phase and if volatile and particulate forms of ruthenium can be reliably captured and with what efficiency. This applies to various off-gas processes, including filters, adsorbers, condensers, and wet scrubbers, that are not specifically 
intended for ruthenium capture. The efficiencies of high-efficiency particulate air (HEPA) filters for particulate $\mathrm{RuO}_{2}$ and of aqueous scrubbers for volatile $\mathrm{RuO}_{4}$ are uncertain. A critical review of the literature and proposed research to close the gaps identified in this review are needed.

- Volatilization of ruthenium-Improved data are needed on the volatilization of ruthenium during TPT. Data about the relationship of quantity released, speciation, and operation conditions (temperature, time, oxygen content etc.) are needed.

- Capacity of metal mesh for Ru-No data exist on the capacity of metal mesh for the capture of ruthenium; thus, sizing of this alternate approach could not be completed.

- Desorption of physisorbed species - Physisorbed iodine exists on iodine-loaded AgZ and, to a lesser extent, on Ag-Aerogel. The quantities are uncertain but important to the operation of the removal process.

- Verification of MOF operating processes-The operating scheme detailed for the MOF, hydrogen mordenite-polyacrylonitrile (HZ-PAN), and silver-exchanged mordenite-polyacrylonitrile (AgZPAN) sorbents has not been fully tested and should be verified experimentally.

- Optimize krypton and xenon desorption-Desorption of krypton and xenon from PAN and MOF has not been optimized in terms of product purity, segregation from co-adsorbed gases, and energy balance. In particular, for the solid xenon and krypton sorbents, co-adsorption of air and other off-gas components impacts the purity of the target gases that are released or stored. Few data are available on this topic, but low sorption of these air and off-gas components on the sorbent has the potential to greatly simplify the removal of xenon and krypton from the off-gas stream, especially if the additional krypton product purification process can be eliminated or simplified. 
Table 1. Capture media criteria and metrics (Jubin, et al. 2016b)

\begin{tabular}{|c|c|c|c|}
\hline Property & Unit & Desired trend & Comments \\
\hline \multicolumn{4}{|c|}{ Metrics for technical performance and physical and chemical characteristics criterion } \\
\hline Capacity & $\mathrm{mol} / \mathrm{m}^{3}$ & High & $\begin{array}{l}\text { The capacity of the bulk material for the radionuclide of interest. Capacity and bulk } \\
\text { density influence sorbent column size. }\end{array}$ \\
\hline Selectivity & $\begin{array}{l}\quad \quad\left(\mathrm{X}_{\mathrm{a}} / \mathrm{Y}_{\mathrm{a}}\right) /\left(\mathrm{X}_{\mathrm{b}} / \mathrm{Y}_{\mathrm{b}}\right) \\
\qquad \quad(\text { unitless) } \\
\text { Where } X_{a} \text { and } X_{b} \text { are mol } \\
\text { fractions of species a and b } \\
\text { respectively in the } \\
\text { adsorbed phase, and } Y_{a} \\
\text { and } Y_{b} \text { are mol fractions of } \\
\text { species a and b in the bulk } \\
\text { phase. }\end{array}$ & High & $\begin{array}{l}\text { The extent to which the target element is concentrated in the capture system compared } \\
\text { with non-targeted elements. It influences how much preprocessing of the incoming off- } \\
\text { gas stream must be done to make the material practicable. It also dictates how much } \\
\text { post-processing may be required to separate isotopes that should not be mixed (e.g., }{ }^{3} \mathrm{H} \\
\left.\text { and }{ }^{129} \mathrm{I}\right) \text { before conversion to a final waste form. }\end{array}$ \\
\hline Particle density & $\mathrm{kg} / \mathrm{m}^{3}$ & High & $\begin{array}{l}\text { Particle density is the density of the sorbent media and included internal pore volume. } \\
\text { This is in contrast to the bulk density that is the average density of the sorbent bed taking } \\
\text { into account the inter-particle void volume. Density, along with capacity, influences } \\
\text { sorbent column size. There is a balance between the density and the permeability of the } \\
\text { sorbent bed that should be considered and may set an upper density limit. High densities } \\
\text { can negatively affect the sorption kinetics of the target element on the sorbent. }\end{array}$ \\
\hline Surface area & $\mathrm{m}^{2} / \mathrm{g}$ & High & $\begin{array}{l}\text { Increased surface area can promote the efficiency of the sorbent. This is not the } \\
\text { geometric surface area of the particles, but the gas active surface area, as likely measured } \\
\text { by the Brunauer-Emmett-Teller method. }\end{array}$ \\
\hline $\begin{array}{l}\text { Specific heat } \\
\text { capacity }\end{array}$ & $\mathrm{J} /(\mathrm{K} \cdot \mathrm{kg})$ or $\mathrm{J} /\left(\mathrm{K} \cdot \mathrm{m}^{3}\right)$ & $\begin{array}{l}\text { Application } \\
\text { dependent }\end{array}$ & $\begin{array}{l}\text { In use, as sorbates load onto the sorbent, the heat of reaction can cause the temperature } \\
\text { of the sorbent to rise. Heat capacity can mitigate this rise. It also affects the time required } \\
\text { to preheat or cool a sorbent column and so may have implications for process design. }\end{array}$ \\
\hline $\begin{array}{l}\text { Thermal } \\
\text { conductivity }\end{array}$ & $\mathrm{W} /(\mathrm{m} \cdot \mathrm{K})$ & High & $\begin{array}{l}\text { The thermal conductivity should be sufficiently high that the heat of reaction or decay } \\
\text { can be dissipated sufficiently to maintain a desired bed temperature and to avoid } \\
\text { significant thermal gradients within the sorbent bed. This is a key property for the design } \\
\text { and size of systems that need to be heated or cooled. }\end{array}$ \\
\hline Radiation stability & $\begin{array}{l}\% \text { degradation in capacity } \\
\text { over time as a function of } \\
\text { radiation exposure }\end{array}$ & $\begin{array}{l}\text { High stability; } \\
\text { low degradation } \\
\text { over time }\end{array}$ & $\begin{array}{l}\text { Intense background radiation and radioactive sorbates can cause substantial damage to } \\
\text { the sorbent, especially those isotopes with high specific activity }\left({ }^{3} \mathrm{H} \text { and }{ }^{85} \mathrm{Kr} \text { ). This can }\right. \\
\text { affect basic sorbent properties (such as capacity, selectivity) and sorbent lifetime. }\end{array}$ \\
\hline
\end{tabular}


Table 1. Capture media criteria and metrics (Jubin, et al. 2016b) (continued)

\begin{tabular}{|c|c|c|c|}
\hline Property & Unit & Desired trend & Comments \\
\hline Mechanical stability & $\begin{array}{l}\text { Generated fines }<420 \mu \mathrm{m} \\
\text { with losses to the off-gas } \\
\text { stream of }<50 \mu \mathrm{g} / \mathrm{m}^{3}\end{array}$ & $\begin{array}{l}\text { High stability; } \\
\text { low fines } \\
\text { generation }\end{array}$ & $\begin{array}{l}\text { High gas velocities, chemical reactions, and other plant variables can cause the bed } \\
\text { packing to vibrate and cause some attrition of the particles that make up the bed. } \\
\text { Attrition can yield fine airborne particles that may affect downstream processes, cause } \\
\text { premature failure of the HEPA filters, and, perhaps, affect facility DF. The ability to } \\
\text { limit these losses is reflected by a particle's mechanical stability. }\end{array}$ \\
\hline Thermal stability & $\begin{array}{l}\% \text { degradation in capacity } \\
\text { over time at selected } \\
\text { operating temperature }\end{array}$ & $\begin{array}{c}\text { High stability; } \\
\text { low degradation } \\
\text { over time }\end{array}$ & $\begin{array}{l}\text { Thermal stability over both the normal operating and process upset condition } \\
\text { temperature ranges is necessary. }\end{array}$ \\
\hline Chemical stability & $\begin{array}{l}\text { \% degradation in capacity } \\
\text { over time as a function of } \\
\text { other species present in gas } \\
\text { stream }\end{array}$ & $\begin{array}{l}\text { High stability; } \\
\text { low degradation } \\
\text { over time }\end{array}$ & Impacts the operating life and performance of the sorbent. \\
\hline Reactivity & $\begin{array}{l}\text { Compatibility as } \\
\text { determined by standardized } \\
\text { compatibility tables }\end{array}$ & $\begin{array}{l}\text { Demonstrated } \\
\text { compatibility } \\
\text { with all } \\
\text { components of } \\
\text { gas stream and } \\
\text { materials of } \\
\text { construction }\end{array}$ & $\begin{array}{l}\text { A measure of the interaction between the sorbent and materials of construction and other } \\
\text { gas stream components. }\end{array}$ \\
\hline \multicolumn{4}{|c|}{ Metrics for technical practicality criterion } \\
\hline Regeneration & $\begin{array}{l}\text { No. of cycles before } \\
\text { degrading to } 80 \% \text { of } \\
\text { capacity for the target } \\
\text { element }\end{array}$ & High & $\begin{array}{l}\text { This property affects the overall plant design and cost of operation. Some materials may } \\
\text { not be regenerated, i.e., they are single use. }\end{array}$ \\
\hline Bulk density & $\mathrm{kg} / \mathrm{m}^{3}$ & High & $\begin{array}{l}\text { Bulk density is the average density of the sorbent bed taking into account the particle } \\
\text { density and the intra-particle void volume, i.e., the mass of the sorbent }(\mathrm{kg}) \text { divided by } \\
\text { the volume of the packed bed }\left(\mathrm{m}^{3}\right) \text {. Bulk density impacts bed size, pressure drop, and } \\
\text { surface area available for reaction. Increases in bulk density approaching the particle } \\
\text { density in the limiting case will result in the smallest bed size but excessive pressure } \\
\text { drop. }\end{array}$ \\
\hline Co-adsorbed species & $\mathrm{mol} / \mathrm{kg}$ & $\begin{array}{l}\text { Small in } \\
\text { number of } \\
\text { species and } \\
\text { quantity }\end{array}$ & $\begin{array}{l}\text { Indicates how much the overall capacity of the sorbent is affected by sorption of non- } \\
\text { targeted elements. Tramp elements or isotopes (e.g., } \mathrm{Cl},{ }^{12} \mathrm{C}, \mathrm{Xe} \text {, and so on) fall into this } \\
\text { category. }\end{array}$ \\
\hline
\end{tabular}


Table 1. Capture media criteria and metrics (Jubin, et al. 2016b) (continued)

\begin{tabular}{|c|c|c|c|}
\hline Property & Unit & Desired trend & Comments \\
\hline Robustness & $\begin{array}{l}\% \text { variation in operating } \\
\text { parameters tolerated } \\
\text { without deleterious effects }\end{array}$ & High & Tolerance to process upset conditions. \\
\hline $\begin{array}{l}\text { Flexibility and } \\
\text { pretreatment }\end{array}$ & $\begin{array}{l}\text { Operating ranges; no. of } \\
\text { unit operations for } \\
\text { pretreatment }\end{array}$ & $\begin{array}{c}\text { High flexibility; } \\
\text { minimal } \\
\text { pretreatment }\end{array}$ & The width of the sorbent standard operating envelope. \\
\hline Process complexity & $\begin{array}{l}\text { No. and type of control } \\
\text { systems and unit operations } \\
\text { required. }\end{array}$ & Low & Affects the cost, volume, and footprint of the treatment system. \\
\hline Energy consumption & $\mathrm{kW} / \mathrm{mol}$ & Low & This is the energy required to effect separation of the target element. \\
\hline $\begin{array}{l}\text { Environmental } \\
\text { safety and health }\end{array}$ & $\begin{array}{l}\text { Classification according to } \\
\text { National Fire Protection } \\
\text { Association ratings }\end{array}$ & Low & $\begin{array}{l}\text { Other applicable hazard classification systems may be used as appropriate (e.g., safety } \\
\text { data sheet, American Society for Testing and Materials, Uniform Fire Code, } \\
\text { International Fire Code, American National Standards Institute, and local and state } \\
\text { codes). }\end{array}$ \\
\hline \multicolumn{4}{|c|}{ Metrics for system design and performance criterion } \\
\hline Pressure drop & $\mathrm{Pa} / \mathrm{m}$ & Low & $\begin{array}{l}\text { Pressure drop should be minimal to avoid operational difficulties. This value is affected } \\
\text { by sorbent densities and bed size. }\end{array}$ \\
\hline $\begin{array}{l}\text { Decontamination } \\
\text { factor (DF) }\end{array}$ & $\begin{array}{c}{[\text { Isotope }]_{a} /[\text { Isotope }]_{b}} \\
\text { (unitless) }\end{array}$ & High & Regulatory requirements dictate the value for specific isotopes. \\
\hline Bed volume & $\mathrm{m}^{3}$ & Low & $\begin{array}{l}\text { Bed volume is a function of the capacity, particle density, and bulk density of the sorbent } \\
\text { material. }\end{array}$ \\
\hline \multicolumn{4}{|c|}{ Metrics for technical maturity criterion } \\
\hline $\begin{array}{l}\text { Technology } \\
\text { readiness level of } \\
\text { sorbent system }\end{array}$ & $1-9$ & High & $\begin{array}{l}\text { The technology readiness level is defined in the technology readiness assessment report } \\
\text { (DoD 2011). }\end{array}$ \\
\hline $\begin{array}{l}\text { Commercial } \\
\text { availability }\end{array}$ & Yes/No & $\begin{array}{l}\text { Readily } \\
\text { available }\end{array}$ & $\begin{array}{l}\text { Commercial availability of the sorbent is an important parameter because of the cost of } \\
\text { producing a material "in house." However, some sorbents can be made in place, such as } \\
\text { a } \mathrm{AgNO}_{3} \text { solution on an inert substrate }\left(\mathrm{e} . \mathrm{g} ., \mathrm{Al}_{2} \mathrm{O}_{3}\right) \text {. Commercial availability eliminates } \\
\text { the need to build infrastructure and accrues the benefit of scale because material is made } \\
\text { for a number of customers. }\end{array}$ \\
\hline
\end{tabular}


Data Requirements and Test System Needs for Development of an Integrated Off-Gas Treatment

System

Table 1. Capture media criteria and metrics (Jubin, et al. 2016b) (continued)

\begin{tabular}{|c|c|c|l|}
\hline Property & Unit & Desired trend & \multicolumn{1}{|c|}{ Comments } \\
\hline $\begin{array}{c}\text { Time to } \\
\text { commercialization }\end{array}$ & $\mathrm{y}$ & Short & This must be compatible with the construction of the reprocessing facility. \\
\hline \multicolumn{3}{|c|}{ Metrics for cost criterion } \\
\hline $\begin{array}{c}\text { Cost of sorbent } \\
\text { material }\end{array}$ & $\$ / \mathrm{kg}, \$ / \mathrm{Ci}$, or $\$ / \mathrm{mol}$ & Low & Cost of sorbent and any associated consumable materials. \\
\hline Operating cost & $\$ / \mathrm{Ci}$ & Low & Cost to operate the capture system. \\
\hline
\end{tabular}


It should be noted that as the data gaps were being enumerated it was necessary to expand the metrics slightly to capture co-adsorption effects and to address desorption. The metrics for bulk density and coabsorbed species were moved to the criterion that captured the metrics for chemical and physical properties. For the purposes of this evaluation, the criteria for technical maturation and cost were not considered.

\section{DATA GAPS}

\subsection{Ruthenium recovery systems}

During the preparation of the Engineering Evaluation it became apparent that very little data were available that could be directly applied to the design and sizing of a ruthenium recovery/abatement system. Limited data were available on the fraction of ruthenium volatilized either in the TPT system or dissolver, and speciation data was unavailable. Although these data are critical to the design of the recovery systems, these data should be obtained as part of the development of the TPT system and dissolver system, along with other relevant data that would further refine the off-gas source terms.

Table 2 summarizes the data gaps and the data requirements for the Ru capture system. These gaps follow the same structure as described in the criteria report but focus primarily on the properties of the sorbent materials and key operational parameters.

Because of the lack of data that can be used to design the systems, the most important data gap to be filled is to obtain data on the Ru capacity of the silica gel sorbent and selected metal mesh material as a function of Ru concentration in the off-gas stream (Gap ID \#1). The next most critical is the determination of the co-absorbed species and their impact on the Ru adsorption capacity. (Gap ID \#3 and \#5). Of particular importance is the impact of water/acid vapor on the silica gel sorbent capture efficiency for systems similar to the dissolver off-gas. Addressing these three gaps will allow a significant refinement in the sizing of the Ru capture system.

Second tier data gaps include the determination of the adsorption rates (Gap ID \#2, \#4, and \#6) as these will aid in the determination of the required length of the bed to achieve the desired $\mathrm{Ru}$ decontamination factor.

It may be possible to collect all of this initial data in a thermal gravimetric analyzer (TGA)-type system using thin beds containing gram quantities of sorbent or in a deep-bed system in which multiple layers are analyzed. A major challenge in this effort is the generation of an appropriate Ru-containing simulant offgas stream.

The third tier data needs include the validation of the system DF and length of the MTZ (Gap ID \#24 and \#25). This will allow further refinement of the design bed length to allow the major portion of the bed to achieve saturation before breakthrough. These tests will require a deep sorbent configuration. The greatest complexity of the test systems described thus far is the increasing complexity of the off-gas supply system required to challenge the sorbent material with more and more prototypic off-gas concentrations. These systems will contain grams to kilograms of sorbent initially. The use of radioactive tracers should also be considered as the number of off-gas components is increased to allow more accurate determination of the co-adsorption capacity of the various $\mathrm{Ru}$ adsorbents.

The data gaps for the thermal properties are considered a lower priority at this time. Finally, the data gaps that address the regeneration of the sorbent are currently the lowest priority as it is currently thought that the $\mathrm{Ru}$ sorbent is a one-time use material.

Testing of the Ru sorbent and the back-flushable filter should be considered, assuming a suitable $\mathrm{Ru}$ and fuel solids simulant feed system can be developed. Testing this integrated subsystem should be completed 
to demonstrate the Ru DF across the filter and to determine the rate of Ru accumulation on the filter media.

Integrated testing should be conducted that includes the coupling of the Ru abatement system with the iodine capture and tritium capture and recovery systems. This should be completed for both TPT off-gas (TPTOG) stream and dissolver system conditions with a particular focus on the long-term effects of water vapor on the Ru recovery system, as well as the potential accumulation of $\mathrm{Ru}$ within the tritium capture systems. Although the direct-dissolution-of- fuel-without-TPT analysis case did not include tritium capture on the dissolver or VOG lines, a recent analysis by Jubin and Spencer (2017) indicates that in the absence of TPT tritium capture may be required on the DOG and VOG systems. 
Table 2. Data gaps for ruthenium sorbent evaluations

\begin{tabular}{|c|c|c|c|c|c|}
\hline$\#$ & Property & Specific requirements & Approach & Data gap impact & Notes \\
\hline \multicolumn{6}{|c|}{ Metrics for technical performance and physical and chemical characteristics criterion } \\
\hline 1 & $\begin{array}{c}\text { Adsorption capacity } \\
\mathrm{mol} / \mathrm{kg} \text { sorbent }\end{array}$ & $\begin{array}{l}\text { Maximum capacity of selected } \\
\text { sorbent material as a function of } \\
\text { Ru species, temperature, and } \\
\text { concentration. } \\
\text { - } \quad \text { Ru species of interest are } \\
\quad \text { may include } \mathrm{RuO}_{4}, \mathrm{RuI}_{4}, \\
\text { and } \mathrm{RuBr}_{4} \text {. } \\
\text { Operating temperature } \\
\text { range is } 30^{\circ} \mathrm{C}-600^{\circ} \mathrm{C} \text {. } \\
\text { Ru concentration ranging } \\
\text { from } 1 \times 10^{-7} \mathrm{~kg} / \mathrm{m}^{3} \text { to } \\
1 \times 10^{-4} \mathrm{~kg} / \mathrm{m}^{3} \text {. } \\
\text { Gas velocities ranging from } \\
5 \text { to } 100 \mathrm{~m} / \mathrm{min} \text {. } \\
\end{array}$ & $\begin{array}{l}\text { Thin-bed testing } \\
\text { Test system must be able } \\
\text { to hold a thin bed of } \\
\text { sorbent at given } \\
\text { temperature and expose } \\
\text { sorbent to a generated air } \\
\text { stream containing water } \\
\text { (and any potentially co- } \\
\text { adsorbed species) at } \\
\text { varying concentrations } \\
\text { within the specified } \\
\text { concentration range and } \\
\text { gas velocity. }\end{array}$ & Equipment size & $\begin{array}{l}\text { Only limited data found in the literature on } \\
\text { silica gel capacity. }\end{array}$ \\
\hline 2 & $\begin{array}{l}\text { Capture/removal } \\
\text { rates for primary } \\
\text { species } \\
\mathrm{mol} / \mathrm{kg} \text { sorbent/h }\end{array}$ & $\begin{array}{l}\text { Adsorption rate data for selected } \\
\text { sorbent as function of } \mathrm{Ru} \\
\text { species, temperature, and } \\
\text { concentration. } \\
\text { Recommended experimental } \\
\text { ranges and Ru species are } \\
\text { provided in Gap ID \#1. }\end{array}$ & $\begin{array}{l}\text { Thin-bed testing } \\
\text { (See Gap ID \#1) }\end{array}$ & Equipment size & \\
\hline
\end{tabular}


Data Requirements and Test System Needs for Development of an Integrated Off-Gas Treatment

Table 2. Data gaps for ruthenium sorbent evaluations (continued)

\begin{tabular}{|c|c|c|c|c|c|}
\hline \# & Property & Specific requirements & Approach & Data gap impact & Notes \\
\hline 3 & $\begin{array}{c}\text { Capacity for other } \\
\text { species present in gas } \\
\text { stream } \\
\mathrm{mol} / \mathrm{kg} \text { sorbent }\end{array}$ & $\begin{array}{l}\text { Maximum capacity for potential } \\
\text { co-absorbed species by selected } \\
\text { sorbent material as a function of } \\
\text { species, temperature, and } \\
\text { concentration. } \\
\text { - } \quad \text { Species of interest are } \mathrm{H}_{2} \mathrm{O} \text {, } \\
\mathrm{O}_{2}, \mathrm{~N}_{2}, \mathrm{HNO}_{3}, \mathrm{CO}_{2}, \mathrm{I}, \text { etc. } \\
\text { - } \quad \mathrm{H}_{2} \mathrm{O} \text { with a dew point of } \\
-60^{\circ} \mathrm{C}-90^{\circ} \mathrm{C} \\
\text { - } \quad \mathrm{HNO}_{3} \text { concentration of } \\
1,000 \text { ppm } \\
\text { - } \quad \mathrm{O}_{2} \text { concentrations from } \\
20 \% \text { to } \sim 100 \% \\
\text { - } \quad \mathrm{N}_{2} \text { concentrations of } 0 \%- \\
80 \% \\
\text { - } \quad \mathrm{CO} 2 \text { concentrations of } \\
440 \text { ppm } \\
\text { - } \mathrm{I} \text { concentrations up to } \\
0.1 \mathrm{~kg} / \mathrm{m}^{3}(10,000 \text { ppm); } \\
\text { Operating temperature } \\
\text { range is } 30^{\circ} \mathrm{C}-600^{\circ} \mathrm{C}\end{array}$ & $\begin{array}{l}\text { Thin-bed testing } \\
(\text { See Gap ID \#1) }\end{array}$ & $\begin{array}{l}\text { Equipment } \\
\text { size/operational } \\
\text { sequencing }\end{array}$ & \\
\hline 4 & 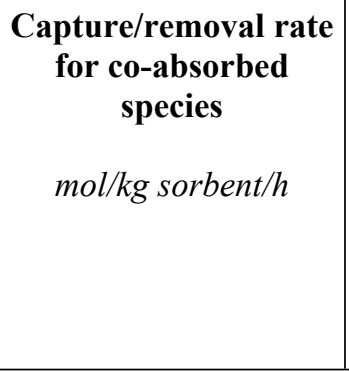 & $\begin{array}{l}\text { Adsorption rate data for selected } \\
\text { sorbent as function of, co- } \\
\text { absorbed species, temperature, } \\
\text { and concentration } \\
\text { Recommended experimental } \\
\text { ranges and potentially } \\
\text { co-adsorbing species are } \\
\text { provided in Gap ID \#3. }\end{array}$ & $\begin{array}{l}\text { Thin-bed testing } \\
\text { (See Gap ID \#1) }\end{array}$ & $\begin{array}{l}\text { Equipment } \\
\text { size/operational } \\
\text { sequencing }\end{array}$ & \\
\hline
\end{tabular}


Table 2. Data gaps for ruthenium sorbent evaluations (continued)

\begin{tabular}{|c|c|c|c|c|c|}
\hline \# & Property & Specific requirements & Approach & Data gap impact & Notes \\
\hline 5 & $\begin{array}{c}\text { Change in sorbent } \\
\text { capacity for Ru in } \\
\text { presence of other } \\
\text { species present in gas } \\
\text { stream } \\
\mathrm{mol} / \mathrm{kg} \text { sorbent }\end{array}$ & $\begin{array}{l}\text { Ru capacity of selected sorbent } \\
\text { material for potential adverse } \\
\text { effects to Ru capacity in the } \\
\text { presence of co-absorbed species } \\
\text { function of species, temperature, } \\
\text { and concentration. } \\
\text { Recommended experimental } \\
\text { ranges, Ru species, and } \\
\text { potentially co-adsorbing species } \\
\text { are provided in Gap IDs \#1 and } \\
\# 3 \text {. }\end{array}$ & 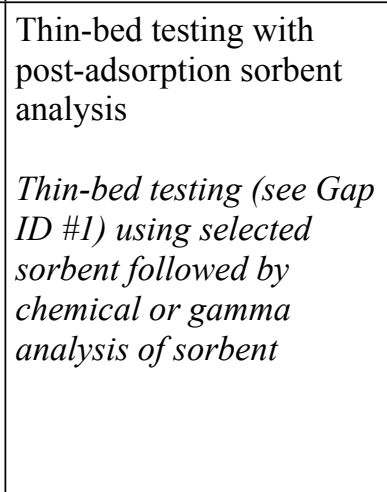 & Equipment size & \\
\hline 6 & $\begin{array}{l}\text { Change in } \mathbf{R u} \\
\text { capture rate in } \\
\text { presence of co- } \\
\text { absorbed species } \\
\mathrm{mol} / \mathrm{kg} \text { sorbent/h }\end{array}$ & $\begin{array}{l}\text { Ru adsorption rate data for } \\
\text { selected sorbent as function of, } \\
\text { co-absorbed species, } \\
\text { temperature, and concentration. } \\
\text { Recommended experimental } \\
\text { ranges, Ru species, and } \\
\text { potentially co-adsorbing species } \\
\text { are provided in Gap IDs \#1 and } \\
\# 3 \text {. }\end{array}$ & $\begin{array}{l}\text { Thin-bed testing with } \\
\text { post-adsorption sorbent } \\
\text { analysis } \\
\text { (See Gap ID \#5) }\end{array}$ & Equipment size & \\
\hline 7 & $\begin{array}{c}\text { Selectivity } \\
\left(X_{a} / Y_{a}\right) /\left(X_{b} / Y_{b}\right) \\
\text { (unitless) } \\
\text { Where } X_{a} \text { and } X_{b} \text { are } \\
\text { mol fractions of } \\
\text { species a and } b \\
\text { respectively in the } \\
\text { adsorbed phase, and } \\
Y_{a} \text { and } Y_{b} \text { are mol } \\
\text { fractions of species a } \\
\text { and } b \text { in the bulk phase }\end{array}$ & $\begin{array}{l}\text { Derived from data on co- } \\
\text { absorption studies shown above. }\end{array}$ & $\begin{array}{l}\text { Thin-bed testing with } \\
\text { post-adsorption sorbent } \\
\text { analysis } \\
\text { (See Gap ID \#5) }\end{array}$ & $\begin{array}{l}\text { Equipment } \\
\text { size/operational } \\
\text { sequencing }\end{array}$ & \\
\hline
\end{tabular}


Data Requirements and Test System Needs for Development of an Integrated Off-Gas Treatment

Table 2. Data gaps for ruthenium sorbent evaluations (continued)

\begin{tabular}{|c|c|c|c|c|c|}
\hline$\#$ & Property & Specific requirements & Approach & Data gap impact & Notes \\
\hline 8 & $\begin{array}{c}\text { Sorbent particle } \\
\text { density } \\
\mathrm{kg} / \mathrm{m}^{3}\end{array}$ & $\begin{array}{l}\text { Density of individual particles in } \\
\qquad \mathrm{kg} / \mathrm{m}^{3} .\end{array}$ & $\begin{array}{l}\text { Direct measurement or } \\
\text { from manufacturer }\end{array}$ & Equipment size & $\begin{array}{l}\text { Data available from Garg Chemical for silica } \\
\text { gel. }\end{array}$ \\
\hline 9 & $\begin{array}{l}\text { Sorbent bulk density } \\
\mathrm{kg} / \mathrm{m}^{3}\end{array}$ & $\begin{array}{l}\text { Bulk density of bed of sorbent } \\
\text { material in typical loading } \\
\text { configuration in } \mathrm{kg} / \mathrm{m}^{3} \text {. }\end{array}$ & $\begin{array}{l}\text { Direct measurement or } \\
\text { from manufacturer }\end{array}$ & Equipment size & \\
\hline 10 & $\begin{array}{c}\text { Specific heat capacity } \\
\qquad J / K / k g\end{array}$ & $\begin{array}{l}\text { Specific heat capacity of fresh } \\
\text { and loaded sorbent over range of } \\
\text { operating conditions }\left(30^{\circ} \mathrm{C} \text { to }\right. \\
\left.600^{\circ} \mathrm{C}\right) \text {. }\end{array}$ & $\begin{array}{l}\text { Direct measurement of } \\
\text { fresh sorbent and loaded } \\
\text { sorbent }\end{array}$ & Heat duty & \\
\hline 11 & $\begin{array}{c}\text { Thermal conductivity } \\
\qquad \mathrm{W} / \mathrm{m} / \mathrm{K}\end{array}$ & $\begin{array}{l}\text { Thermal conductivity of fresh } \\
\text { and loaded sorbent over range of } \\
\text { operating conditions }\left(30^{\circ} \mathrm{C} \text { to }\right. \\
\left.600^{\circ} \mathrm{C}\right) \text {. }\end{array}$ & $\begin{array}{l}\text { Direct measurement of } \\
\text { fresh sorbent and loaded } \\
\text { sorbent }\end{array}$ & $\begin{array}{l}\text { Heat } \\
\text { duty/operational } \\
\text { sequencing }\end{array}$ & \\
\hline 12 & $\begin{array}{l}\text { Radiation stability } \\
\% \text { degradation in } \\
\text { capacity, adsorption } \\
\text { rate, regeneration } \\
\text { time, and MTZ over } \\
\text { time as a function of } \\
\text { radiation exposure }\end{array}$ & $\begin{array}{l}\text { Total adsorbed dose for } \mathrm{Ru} \\
\text { sorbents assume one time use, } \\
\text { i.e, no regeneration. } \\
\text { Total dose requirement is design } \\
\text { dependent. } \\
\text { Total dose should factor in both } \\
\text { external dose and internal dose. }\end{array}$ & $\begin{array}{l}\text { Irradiation and thin-bed } \\
\text { testing } \\
\text { Exposure of the sorbent to } \\
\text { both } \gamma \text { and } \beta \text { radiation for } \\
\text { a range of total doses. } \\
\text { Testing of the sorbent } \\
\text { with both thin- and deep- } \\
\text { bed testing to } \\
\text { characterize radiation } \\
\text { effects. } \\
\text { (Thin-bed testing: See } \\
\text { Gap IDs \#1 and \#5) }\end{array}$ & Material life cycle & \\
\hline
\end{tabular}


Table 2. Data gaps for ruthenium sorbent evaluations (continued)

\begin{tabular}{|c|c|c|c|c|c|}
\hline$\#$ & Property & Specific requirements & Approach & Data gap impact & Notes \\
\hline 13 & $\begin{array}{l}\text { Mechanical stability } \\
\mathrm{N} / \mathrm{mm} \text { (load vs particle } \\
\text { diameter) } \\
\mu \mathrm{g} / \mathrm{kg} \text { sorbent loss to } \\
\text { gas stream }\end{array}$ & $\begin{array}{l}\text { Determination of the fines } \\
\text { generation and mechanical } \\
\text { strength of the sorbent material. }\end{array}$ & $\begin{array}{l}\text { Direct measurement } \\
\text { Measurements of both } \\
\text { particle crush strength } \\
\text { and abrasion resistance } \\
\text { will be required }\end{array}$ & Material life cycle & \\
\hline 14 & $\begin{array}{l}\text { Thermal stability } \\
\text { \% degradation in } \\
\text { capacity over time at } \\
\text { selected operating } \\
\text { temperature }\end{array}$ & $\begin{array}{l}\text { Determine the extent of capacity } \\
\text { loss due to extended exposure to } \\
\text { operating temperature. } \\
\text { Determine the extent of capacity } \\
\text { loss due to thermal cycling and } \\
\text { excursions. }\end{array}$ & $\begin{array}{l}\text { Extended testing with } \\
\text { thin-bed analysis. } \\
\text { The sorbent should be } \\
\text { exposed to the operating } \\
\text { temperature for extended } \\
\text { periods of time and } \\
\text { should experience thermal } \\
\text { cycling to simulate } \\
\text { regeneration of the } \\
\text { sorbent. The capacity } \\
\text { should be measured after } \\
\text { thermal exposure by thin- } \\
\text { bed testing. } \\
\text { (See Gap ID \#1) }\end{array}$ & Material life cycle & \\
\hline
\end{tabular}


Table 2. Data gaps for ruthenium sorbent evaluations (continued)

\begin{tabular}{|c|c|c|c|c|c|}
\hline$\#$ & Property & Specific requirements & Approach & Data gap impact & Notes \\
\hline 15 & $\begin{array}{c}\text { Chemical stability } \\
\text { \% degradation in } \\
\text { capacity over time as a } \\
\text { function of other } \\
\text { species present in gas } \\
\text { stream }\end{array}$ & $\begin{array}{l}\text { Determine the extent of capacity } \\
\text { loss from extended exposure to } \\
\text { other species present in the off- } \\
\text { gas stream. }\end{array}$ & $\begin{array}{l}\text { Extended testing with } \\
\text { thin-bed analysis. } \\
\text { Age sorbents for various } \\
\text { lengths of time to elevated } \\
\text { levels of each of the non- } \\
\text { target species expected. } \\
\text { Determine Ru capacity } \\
\text { and rates of adsorption. } \\
\text { Differences should be } \\
\text { attributable to aging and } \\
\text { should be a function of } \\
\text { exposure time and non- } \\
\text { target species exposure. }\end{array}$ & Material life cycle & $\begin{array}{l}\text { Unexpected species present in the gas stream, } \\
\text { particularly from upset conditions, impacts the } \\
\text { operating life and performance of the sorbent. }\end{array}$ \\
\hline 16 & $\begin{array}{c}\text { Reactivity } \\
\text { Compatibility as } \\
\text { determined by } \\
\text { standardized } \\
\text { compatibility tables }\end{array}$ & $\begin{array}{l}\text { Confirmation that any } \\
\text { compatibility issues can be } \\
\text { avoided through selection of } \\
\text { materials of construction, } \\
\text { appropriate pretreatment of gas } \\
\text { stream, operational envelope, } \\
\text { etc. }\end{array}$ & Direct evaluation. & Material life cycle & $\begin{array}{l}\text { This examines the interaction between the } \\
\text { sorbent and materials of construction and other } \\
\text { gas stream components. This was assumed not } \\
\text { to be a problem in the Engineering Evaluation } \\
\text { study but was never confirmed. }\end{array}$ \\
\hline 17 & $\begin{array}{c}\text { Regeneration } \\
\text { capacity stability } \\
\text { Number of cycles and } \\
\Delta \mathrm{mol} / \mathrm{kg} \text { sorbent }\end{array}$ & $\begin{array}{l}\text { No. of cycles before degrading } \\
\text { to } 80 \% \text { of capacity for the target } \\
\text { element. }\end{array}$ & $\begin{array}{l}\text { Extended testing with } \\
\text { thin-bed analysis. } \\
\text { Long-term, repeated } \\
\text { testing of select sorbent } \\
\text { over multiple adsorption/ } \\
\text { desorption cycles if } \\
\text { sorbent is to be } \\
\text { regenerated. } N / A \text { if single } \\
\text { use. }\end{array}$ & Material life cycle & $\begin{array}{l}\text { Not currently considered a factor for } \mathrm{Ru} \\
\text { sorbents as these are most likely one time use. }\end{array}$ \\
\hline 18 & $\begin{array}{l}\text { Desorption rate of } \mathbf{R u} \\
\mathrm{mol} / \mathrm{kg} \text { sorbent } / \mathrm{h}\end{array}$ & $\begin{array}{l}\text { Desorption rate as a function of } \\
\text { desorption temperature and } \\
\text { purge stream gas velocity. }\end{array}$ & $\begin{array}{l}\text { Thin-bed testing. } \\
\text { (See Gap ID \#1) }\end{array}$ & Equipment size & \\
\hline
\end{tabular}


Table 2. Data gaps for ruthenium sorbent evaluations (continued)

\begin{tabular}{|c|c|c|c|c|c|}
\hline \# & Property & Specific requirements & Approach & Data gap impact & Notes \\
\hline 19 & $\begin{array}{l}\text { Desorption of co- } \\
\text { adsorbed species } \\
\text { mol co-adsorbed } \\
\text { species retained } / \mathrm{m}^{3} \\
\text { sorbent }\end{array}$ & $\begin{array}{l}\% \text { of co-adsorbed species } \\
\text { desorbed during selected } \\
\text { regeneration conditions. } \\
\text { Recommended experimental } \\
\text { ranges and potentially co- } \\
\text { adsorbing species are provided } \\
\text { in Gap ID \#3. }\end{array}$ & $\begin{array}{l}\text { Thin-bed testing. } \\
\text { (See Gap ID \#1) }\end{array}$ & Material life cycle & \\
\hline 20 & $\begin{array}{c}\text { Desorption rate of co- } \\
\text { adsorbed species } \\
\text { mol/kg sorbent/h }\end{array}$ & $\begin{array}{l}\text { Desorption rate as a function of } \\
\text { desorption temperature and } \\
\text { purge stream gas velocity. } \\
\text { Recommended experimental } \\
\text { ranges and potentially co- } \\
\text { adsorbing species are provided } \\
\text { in Gap ID \#3. }\end{array}$ & $\begin{array}{l}\text { Thin-bed testing. } \\
\text { (See Gap ID \#1) }\end{array}$ & Material life cycle & \\
\hline 21 & $\begin{array}{l}\text { Purity of recovered } \\
\qquad \mathbf{R u} \\
\text { mol impurity } / \mathrm{kg} R u\end{array}$ & $\begin{array}{l}\text { Prescribed by waste treatment } \\
\text { operation. }\end{array}$ & $\begin{array}{l}\text { ICP-MS of recovered } \\
\text { phase. }\end{array}$ & $\begin{array}{l}\text { Equipment size } \\
\text { and waste } \\
\text { treatment process } \\
\text { design }\end{array}$ & $\begin{array}{l}\text { Not considered because current design is single } \\
\text { use. }\end{array}$ \\
\hline 22 & $\begin{array}{l}\text { Cooling time } \\
\qquad h\end{array}$ & $\begin{array}{l}\text { Hours to cool from regeneration } \\
\text { temperature to adsorbing } \\
\text { temperature }\left(30^{\circ} \mathrm{C}\right)\end{array}$ & $\begin{array}{l}\text { Derived from heat } \\
\text { capacity, thermal } \\
\text { conductivity, and bed } \\
\text { design. }\end{array}$ & Heat duty & $\begin{array}{l}\text { Readily derived and confirmed during deep-bed } \\
\text { testing. Not considered because current design } \\
\text { is single use. }\end{array}$ \\
\hline \multicolumn{6}{|c|}{ Metrics for system design and performance criterion } \\
\hline 23 & $\begin{array}{c}\text { Pressure drop } \\
\text { Pa/m vs } m^{2} \text { column }\end{array}$ & $\begin{array}{l}\text { Size columns and sorbent size } \\
\text { for }<2.5 \mathrm{kPa} \text { pressure drop based } \\
\text { on expected gas flow rates. }\end{array}$ & $\begin{array}{l}\text { Direct measurement or } \\
\text { scaled derivation. }\end{array}$ & $\begin{array}{l}\text { Operational } \\
\text { sequencing/equip } \\
\text { ment size }\end{array}$ & $\begin{array}{l}\text { Not considered directly in Engineering } \\
\text { Evaluation. }\end{array}$ \\
\hline
\end{tabular}


Table 2. Data gaps for ruthenium sorbent evaluations (continued)

\begin{tabular}{|c|c|c|c|c|c|}
\hline$\#$ & Property & Specific requirements & Approach & Data gap impact & Notes \\
\hline 24 & $\begin{array}{c}\text { Decontamination } \\
\text { factor (DF) } \\
{[R u]_{\text {inlet }} /[R u]_{\text {outlet }}} \\
\text { (unitless) }\end{array}$ & $\begin{array}{l}\text { DF data as function of sorbent, } \\
\text { Ru species, temperature, } \\
\text { concentration, time, and bed } \\
\text { depth. } \\
\text { Recommended experimental } \\
\text { ranges and Ru species are } \\
\text { provided in Gap ID \#1. }\end{array}$ & $\begin{array}{l}\text { Deep-bed testing with } \\
\text { online measurement of } \\
\text { inlet and effluent } \mathrm{Ru} \\
\text { concentrations. } \\
\text { Test system must be able } \\
\text { to hold a deep bed of } \\
\text { sorbent at given } \\
\text { temperature and expose } \\
\text { sorbent to a generated air } \\
\text { stream containing water } \\
\text { (and any potentially co- } \\
\text { adsorbed species) at } \\
\text { varying concentrations } \\
\text { within the specified } \\
\text { concentration range and } \\
\text { gas velocity. Both inlet } \\
\text { and effluent gas streams } \\
\text { must be assessed for Ru } \\
\text { concentration. }\end{array}$ & $\begin{array}{l}\text { Equipment } \\
\text { size/operational } \\
\text { sequencing }\end{array}$ & $\begin{array}{l}\text { This is actually a function of the overall system } \\
\text { design but the ability to demonstrate that the } \\
\text { assumed DF is achievable is needed for a } \\
\text { comparable design. }\end{array}$ \\
\hline 25 & $\begin{array}{l}\text { Length of Mass } \\
\text { Transfer Zone } \\
\text { (MTZ) } \\
m\end{array}$ & $\begin{array}{l}\text { Length of MTZ as a function of } \\
\text { gas velocity, target species } \\
\text { concentration, temperature, and } \\
\text { presence of co-absorbed species } \\
\text { shown to have impact on total } \\
\text { capacity or adsorption rate } \\
>10 \% \text {. } \\
\text { Recommended experimental } \\
\text { ranges and Ru species are } \\
\text { provided in Gap ID \#1. }\end{array}$ & $\begin{array}{l}\text { Deep-bed tests with bed } \\
\text { depth that captures } 1.5 \\
\text { times MTZ. Predictions } \\
\text { can be made from thin- } \\
\text { bed tests and data may } \\
\text { also be determined from } \\
\text { DF testing using deep } \\
\text { beds. } \\
\text { (Deep-bed testing: Gap } \\
\text { ID \#24). }\end{array}$ & Equipment size & \\
\hline
\end{tabular}




\subsection{Tritium recovery systems}

Tritium $\left({ }^{3} \mathrm{H}\right)$ present in the off-gas generated by air TPT process will be present as tritiated water $\left({ }^{3} \mathrm{H}_{2} \mathrm{O}\right.$ or $\left.{ }^{3} \mathrm{H}^{1} \mathrm{HO}\right)$ and will range in concentration from $1 \times 10^{-7} \mathrm{~kg} / \mathrm{m}^{3}$ to $1 \times 10^{-4} \mathrm{~kg} / \mathrm{m}^{3}(0.1-100 \mathrm{ppm})$. Several commercially available sorbents are suitable for water removal (gas drying) and of, those molecular sieves (MS) 3A, 4A, 5A, etc. are promising candidates for use in a nuclear fuel reprocessing facility because of their robust physical and chemical properties. The Engineering Evaluation found that water removal by 3A MS was relatively well understood in comparison to other treatment operations reviewed, but there were still a number of outstanding data gaps that could substantially impact the unit design. Table 3 summarizes the data gaps and requirements for the tritium capture system. These gaps follow the same structure described in the criteria report but focus primarily on the properties of the sorbent materials and key operational parameters.

The most substantial data gaps limiting the refinement of the tritium removal system design are related to the co-adsorption of other off-gas species, both radioactive species requiring mitigation and other gaseous makeup components, such as $\mathrm{CO}_{2}$. These gaps include the capacity of $3 \mathrm{~A}$ MS for other species present in gas stream, the rate of adsorption by $3 \mathrm{~A}$ MS for other species present in gas stream, the change in sorbent capacity for $\mathrm{H}_{2} \mathrm{O}$ in presence of other species present in gas stream, the change in the $\mathrm{H}_{2} \mathrm{O}$ capture rate in the presence of co-absorbed species, and the selectivity of $3 \mathrm{~A} \mathrm{MS}$ for $\mathrm{H}_{2} \mathrm{O}$ over other potentially coadsorbing species (Gap ID \#3-7). These gaps are most likely to affect equipment size, but they could also affect operational sequencing or material life cycle. Co-adsorption data for the tritium removal system is especially important because of its location in the air TPT treatment train. Ruthenium is likely to be removed before the tritium removal unit. Iodine may be removed to address known co-adsorption issues, but the tritium sorbent will be contacted by a number of other constituents of interest (i.e., $\mathrm{CO}_{2}, \mathrm{NO}_{\mathrm{x}}$, and $\mathrm{Kr} / \mathrm{Xe}$ ). These components could affect not only the size and operation of the tritium removal system, but also the downstream source terms should 3A MS remove substantial quantities of the potentially coadsorbing species. The regeneration systems and tritium recovery, concentration, and solidification processes could be impacted.

Initially, thin-bed testing to determine the extent to which potentially co-adsorbing species adsorb on $3 \mathrm{~A}$ MS will be helpful in eliminating some of these species as co-adsorbers, but to date no testing has been conducted on this topic. If any species is identified as co-adsorbing, a combination of both thin- and deepbed testing will be required to respond to Gaps ID \#3-7. With the exception of gathering co-adsorption rate data, the systems required do not represent a substantial challenge in design or fabrication.

The other major data gaps relating to tritium removal by $3 \mathrm{~A}$ MS are related to desorption of both $\mathrm{H}_{2} \mathrm{O}$ and any co-adsorbed species (Gap ID \#18-21). The desorption of $\mathrm{H}_{2} \mathrm{O}$ has only been characterized under limited conditions. Desorption (or lack thereof) of co-adsorbed species should also be characterized as it may affect material life cycle or equipment sizing. Characterization of the desorption of co-adsorbed species should be done after the identification of co-adsorbed species has been determined. All desorption testing requires the same test equipment that is needed for characterizing $\mathrm{H}_{2} \mathrm{O}$ adsorption and coadsorption of other gaseous species.

The regeneration systems and tritium recovery, concentration, and solidification processes could be impacted by the desorption characteristics of $\mathrm{H}_{2} \mathrm{O}$ and any co-adsorbed species. Multicycle testing of the adsorption, desorption, and regeneration coupled with tritium recovery for disposal should be demonstrated in an integrated fashion. This would require a multicolumn system to demonstrate all aspects of the complete process.

Integrated testing that should be conducted includes coupling of the tritium capture and recovery systems and the iodine capture systems with the $\mathrm{Ru}$ abatement system. This should be completed for both the TPTOG stream as well as the dissolver system conditions with a particular focus on the long-term effects of water vapor on the Ru recovery system as well as the potential accumulation of $\mathrm{Ru}$ within the tritium 
capture systems. Although the direct dissolution of the fuel without TPT analysis case did not include tritium capture on the dissolver or VOG lines, a recent analysis by Jubin and Spencer (2017) indicates that, in the absence of TPT, tritium capture may be required on the DOG and VOG systems. Of particular importance is the evaluation of the long-term effects of water vapor on the Ru sorbent and the selective recovery of tritium-contaminated water for conversion to a stable waste form. 
Table 3. Data needs for tritium sorbents-Air TPT case

\begin{tabular}{|c|c|c|c|c|c|}
\hline \# & $\begin{array}{c}\text { Property } \\
\text { Units }\end{array}$ & Specific requirements & Approach & Data gap impact & Notes \\
\hline \multicolumn{6}{|c|}{ Metrics for technical performance and physical and chemical characteristics criterion } \\
\hline 1 & $\begin{array}{c}\begin{array}{c}\text { Adsorption } \\
\text { capacity }\end{array} \\
\mathrm{mol} / \mathrm{kg}\end{array}$ & 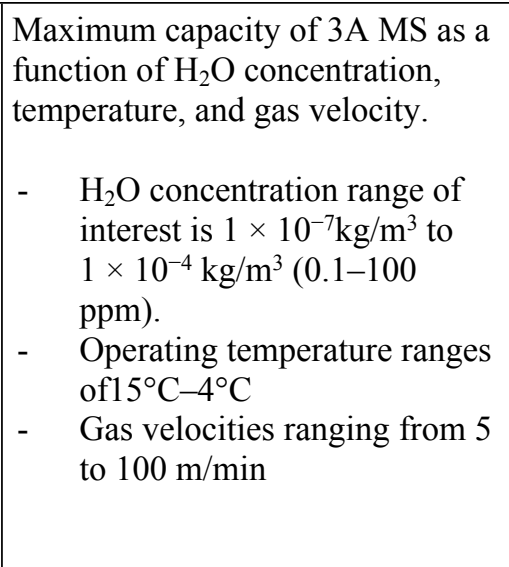 & \begin{tabular}{|l|} 
Thin-bed testing. \\
Test system must be able \\
to hold a thin bed of \\
sorbent at given \\
temperature and expose \\
sorbent to a generated air \\
stream containing water \\
(and any potentially co- \\
adsorbed species) at \\
varying concentrations \\
within the specified \\
concentration range and \\
gas velocity.
\end{tabular} & Equipment size & $\begin{array}{l}\text { Isotherms for } 3 \mathrm{~A} \text { MS sorbents are available } \\
\text { over a range of operating temperatures and } \\
\mathrm{H}_{2} \mathrm{O} \text { concentrations. } \\
\text { Previous work by the Off-Gas Sigma Team has } \\
\text { characterized adsorption of } \mathrm{H}_{2} \mathrm{O} \text { by } 3 \mathrm{~A} \text { MS at } \\
\text { feed stream dew points ranging from }-10^{\circ} \mathrm{C} \text { to } \\
10^{\circ} \mathrm{C} \text { and sorbent temperature of } 30^{\circ} \mathrm{C} \text { (gas } \\
\text { velocity } 10 \mathrm{~m} / \mathrm{min} \text { ). }\end{array}$ \\
\hline 2 & $\begin{array}{l}\text { Capture/removal } \\
\text { rates for primary } \\
\text { species } \\
\text { mol/kg sorbent } / \mathrm{h}\end{array}$ & $\begin{array}{l}\text { Adsorption rate data for } 3 \mathrm{~A} \text { MS as } \\
\text { function of concentration and } \\
\text { temperature. } \\
\text { Recommended experimental } \\
\text { ranges are provided in Gap ID \#1. }\end{array}$ & $\begin{array}{l}\text { Thin-bed testing } \\
\text { (See Gap ID \#1) }\end{array}$ & Equipment size & $\begin{array}{l}\text { OGST has characterized adsorption of } \mathrm{H}_{2} \mathrm{O} \text { by } \\
3 \mathrm{~A} \mathrm{MS} \text { at feed stream dew points ranging from } \\
-10^{\circ} \mathrm{C} \text { to } 10^{\circ} \mathrm{C} \text { and sorbent temperature of } \\
30^{\circ} \mathrm{C} \text { (gas velocity } 10 \mathrm{~m} / \mathrm{min} \text { ). }\end{array}$ \\
\hline
\end{tabular}


Data Requirements and Test System Needs for Development of an Integrated Off-Gas Treatment

Table 3. Data needs for tritium sorbents-Air TPT case (continued)

\begin{tabular}{|c|c|c|c|c|c|}
\hline \# & $\begin{array}{c}\text { Property } \\
\text { Units }\end{array}$ & Specific requirements & Approach & Data gap impact & Notes \\
\hline 3 & $\begin{array}{l}\text { Capacity for other } \\
\text { species present in } \\
\text { gas stream } \\
\mathrm{mol} / \mathrm{kg} \text { sorbent }\end{array}$ & $\begin{array}{l}\text { Maximum capacity for potential } \\
\text { co-absorbed species on } 3 \mathrm{~A} \mathrm{MS} \text { as } \\
\text { a function of species and } \\
\text { concentration } \\
\text { - } \quad \text { Species of interest are } \mathrm{O}_{2}, \\
\mathrm{CO}_{2}, \mathrm{Xe}, \mathrm{Kr}, \mathrm{N}_{2}, \mathrm{NO} \\
\mathrm{O}_{2}(21 \mathrm{vol} \%) \\
\mathrm{CO}(\sim 400 \mathrm{ppm}) \\
\mathrm{Xe}(800 \mathrm{ppm}) \\
\mathrm{Kr}(80 \mathrm{ppm}) \\
\mathrm{N}_{2}(79 \mathrm{vol} \%) \\
\mathrm{Ar}(0.9 \mathrm{vol} \%) \\
\text { - Operating temperature ranges } \\
\text { of } 15^{\circ} \mathrm{C}-40^{\circ} \mathrm{C} \\
\text { - Gas velocities ranging from } 5 \\
\text { to } 100 \mathrm{~m} / \mathrm{min} \\
\end{array}$ & $\begin{array}{l}\text { Thin-bed testing } \\
\text { (See Gap ID \#1) }\end{array}$ & $\begin{array}{l}\text { Equipment } \\
\text { size/operational } \\
\text { sequencing }\end{array}$ & \\
\hline 4 & $\begin{array}{c}\text { Capture/removal } \\
\text { rate for co- } \\
\text { absorbed species } \\
\text { mol/kg sorbent } / \mathrm{h}\end{array}$ & $\begin{array}{l}\text { Adsorption rate data for 3A MS as } \\
\text { function of co-absorbed species, } \\
\text { their concentration, temperature, } \\
\text { and gas velocity. } \\
\text { Species of interest and } \\
\text { recommended experimental ranges } \\
\text { are provided in Gap ID \#3. }\end{array}$ & $\begin{array}{l}\text { Thin-bed testing } \\
\text { (See Gap ID \#1) }\end{array}$ & $\begin{array}{l}\text { Equipment } \\
\text { size/operational } \\
\text { sequencing }\end{array}$ & \\
\hline
\end{tabular}


Data Requirements and Test System Needs for Development of an Integrated Off-Gas Treatment System

Table 3. Data needs for tritium sorbents—Air TPT case (continued)

\begin{tabular}{|c|c|c|c|c|c|}
\hline \# & $\begin{array}{c}\text { Property } \\
\text { Units } \\
\end{array}$ & Specific requirements & Approach & Data gap impact & Notes \\
\hline 5 & $\begin{array}{l}\text { Change in sorbent } \\
\text { capacity for } \mathrm{H}_{2} \mathrm{O} \text { in } \\
\text { presence of other } \\
\text { species present in } \\
\text { gas stream } \\
\mathrm{mol} / \mathrm{kg} \text { sorbent }\end{array}$ & $\begin{array}{l}\mathrm{H}_{2} \mathrm{O} \text { capacity of selected sorbent } \\
\text { material in the presence of co- } \\
\text { absorbed species function of } \\
\text { species and concentration, } \\
\text { temperature, and gas velocity. } \\
\\
\text { Species of interest, their } \\
\text { concentrations, and recommended } \\
\text { experimental conditions are } \\
\text { provided in Gap \#3. }\end{array}$ & $\begin{array}{l}\text { Deep-bed testing with } \\
\text { condensation of desorbed } \\
\mathrm{H}_{2} \mathrm{O} \text {. } \\
\text { Test system must be able } \\
\text { to hold a deep bed of } \\
\text { sorbent at given } \\
\text { temperature and expose } \\
\text { sorbent to a generated air } \\
\text { stream containing water } \\
\text { (and any potentially co- } \\
\text { adsorbed species) at } \\
\text { varying concentrations } \\
\text { within the specified } \\
\text { concentration range and } \\
\text { gas velocity. } \\
\\
\text { The effluent from the deep } \\
\text { bed should be passed } \\
\text { through a cold trap to } \\
\text { condense } \mathrm{H}_{2} \mathrm{O} \text { from the } \\
\text { effluent stream. } \\
\text { Analysis of condensate } \\
\text { will assess whether } \mathrm{H}_{2} \mathrm{O} \\
\text { capacity was affected by } \\
\text { the presence of other } \\
\text { gaseous species. }\end{array}$ & $\begin{array}{l}\text { Equipment } \\
\text { size/operational } \\
\text { sequencing }\end{array}$ & \\
\hline
\end{tabular}


Data Requirements and Test System Needs for Development of an Integrated Off-Gas Treatment

Table 3. Data needs for tritium sorbents-Air TPT case (continued)

\begin{tabular}{|c|c|c|c|c|c|}
\hline \# & $\begin{array}{c}\text { Property } \\
\text { Units } \\
\end{array}$ & Specific requirements & Approach & Data gap impact & Notes \\
\hline 6 & $\begin{array}{l}\text { Change in } \mathrm{H}_{2} \mathrm{O} \\
\text { capture rate in } \\
\text { presence of co- } \\
\text { absorbed species } \\
\mathrm{mol} / \mathrm{kg} \text { sorbent } / \mathrm{h}\end{array}$ & $\begin{array}{l}\mathrm{H}_{2} \mathrm{O} \text { adsorption rate data for } 3 \mathrm{~A} \\
\mathrm{MS} \text { as function of co-absorbed } \\
\text { species, their concentrations, } \\
\text { temperature, and gas velocity. } \\
\text { Species of interest, their } \\
\text { concentrations, and recommended } \\
\text { experimental conditions are } \\
\text { provided in Gap \#3. }\end{array}$ & $\begin{array}{l}\text { Thin-bed testing with } \\
\text { time-resolved sorbent } \\
\text { analysis } \\
\text { Test system must be able } \\
\text { to hold a thin bed of } \\
\text { sorbent at given } \\
\text { temperature and expose } \\
\text { sorbent to a generated air } \\
\text { stream containing water } \\
\text { (and any potentially co- } \\
\text { adsorbed species) at } \\
\text { varying concentrations } \\
\text { within the specified } \\
\text { concentration range and } \\
\text { gas velocity. } \\
\text { The sorbent should be } \\
\text { analyzed during the test } \\
\text { (or the test should be } \\
\text { terminated at discrete } \\
\text { time intervals) to resolve } \\
\text { the contributions of } \mathrm{H}_{2} O \\
\text { (primary species) and co- } \\
\text { adsorbed species to the } \\
\text { observed weight gain. }\end{array}$ & $\begin{array}{l}\text { Equipment } \\
\text { size/operational } \\
\text { sequencing }\end{array}$ & \\
\hline
\end{tabular}


Table 3. Data needs for tritium sorbents—Air TPT case (continued)

\begin{tabular}{|c|c|c|c|c|c|}
\hline \# & $\begin{array}{l}\text { Property } \\
\text { Units } \\
\end{array}$ & Specific requirements & Approach & Data gap impact & Notes \\
\hline 7 & $\begin{array}{c}\text { Selectivity } \\
\left(X_{a} / Y_{a}\right) /\left(X_{b} / Y_{b}\right) \\
\text { (unitless) } \\
\text { Where } X_{a} \text { and } X_{b} \text { are } \\
\text { mol fractions of } \\
\text { species a and } b \\
\text { respectively in the } \\
\text { adsorbed phase, and } \\
Y_{a} \text { and } Y_{b} \text { are mol } \\
\text { fractions of species a } \\
\text { and } b \text { in the bulk } \\
\text { phase }\end{array}$ & Derived from Gap IDs \#1-7 & $\begin{array}{l}\text { Deep-bed testing with } \\
\text { condensation of desorbed } \\
\mathrm{H}_{2} \mathrm{O} \text {. } \\
\text { (See Gap ID \#5) }\end{array}$ & $\begin{array}{l}\text { Equipment } \\
\text { size/operational } \\
\text { sequencing }\end{array}$ & \\
\hline 8 & $\begin{array}{c}\text { Sorbent particle } \\
\text { density } \\
\mathrm{kg} / \mathrm{m}^{3}\end{array}$ & $\begin{array}{l}\text { Density of individual particles in } \\
\mathrm{kg} / \mathrm{m}^{3}\end{array}$ & $\begin{array}{l}\text { Direct measurement or } \\
\text { from manufacturer }\end{array}$ & Equipment size & Available from manufacturer \\
\hline 9 & $\begin{array}{c}\text { Sorbent bulk } \\
\text { density } \\
\mathrm{kg} / \mathrm{m}^{3} \\
\end{array}$ & $\begin{array}{l}\text { Bulk density of bed of sorbent } \\
\text { material in typical loading } \\
\text { configuration in } \mathrm{kg} / \mathrm{m}^{3} \text {. }\end{array}$ & $\begin{array}{l}\text { Direct measurement or } \\
\text { from manufacturer }\end{array}$ & Equipment size & Available from manufacturer \\
\hline 10 & $\begin{array}{c}\text { Specific heat } \\
\text { capacity } \\
J / K / k g\end{array}$ & $\begin{array}{l}\text { Specific heat capacity of fresh and } \\
\text { loaded sorbent as a function of } \\
\text { temperature. } \\
\text { Temperature range of interest is } \\
15^{\circ} \mathrm{C}-40^{\circ} \mathrm{C}\end{array}$ & $\begin{array}{l}\text { Direct measurement or } \\
\text { from manufacturer }\end{array}$ & Heat duty & Available from manufacturer \\
\hline 11 & $\begin{array}{c}\text { Thermal } \\
\text { conductivity } \\
\\
W / m / K\end{array}$ & $\begin{array}{l}\text { Thermal conductivity of fresh and } \\
\text { loaded sorbent as a function of } \\
\text { temperature. } \\
\text { Temperature range of interest is } \\
15^{\circ} \mathrm{C}-40^{\circ} \mathrm{C}\end{array}$ & Direct measurement & $\begin{array}{l}\text { Heat } \\
\text { duty/operational } \\
\text { sequencing }\end{array}$ & Available from manufacturer \\
\hline
\end{tabular}


Data Requirements and Test System Needs for Development of an Integrated Off-Gas Treatment

System

Table 3. Data needs for tritium sorbents—Air TPT case (continued)

\begin{tabular}{|c|c|c|c|c|c|}
\hline \# & $\begin{array}{c}\text { Property } \\
\text { Units }\end{array}$ & Specific requirements & Approach & Data gap impact & Notes \\
\hline 12 & $\begin{array}{l}\text { Radiation stability } \\
\text { \% degradation in } \\
\text { capacity, adsorption } \\
\text { rate, regeneration } \\
\text { time, and MTZ over } \\
\text { time as a function of } \\
\text { radiation exposure }\end{array}$ & $\begin{array}{l}\text { Capacity for } \mathrm{H}_{2} \mathrm{O} \text {, adsorption rate, } \\
\text { and regeneration time for } 3 \mathrm{~A} \mathrm{MS} \\
\text { as a function of adsorbed dose. } \\
\text { Total dose requirement is design } \\
\text { dependent. } \\
\text { Total dose should factor in both } \\
\text { external and internal dose. }\end{array}$ & $\begin{array}{l}\text { Irradiation, thin-bed } \\
\text { testing, and deep-bed } \\
\text { testing } \\
\text { Exposure of the sorbent to } \\
\text { both } \gamma \text { and } \beta \text { radiation for } \\
\text { a range of total doses. } \\
\text { Testing of the sorbent } \\
\text { with both thin- and deep- } \\
\text { bed testing to } \\
\text { characterize radiation } \\
\text { effects. } \\
\text { (Thin-bed testing: See } \\
\text { Gap ID \#1) } \\
\text { (Deep-bed testing: See } \\
\text { Gap ID \#5) }\end{array}$ & Material life cycle & \\
\hline 13 & $\begin{array}{c}\text { Mechanical } \\
\text { stability } \\
N / m m \text { (load } v s \\
\text { particle diameter) } \\
\mu g / m^{3} \text { loss to gas } \\
\text { stream }\end{array}$ & $\begin{array}{l}\text { Determination of the fines } \\
\text { generation and mechanical } \\
\text { strength of the sorbent material. }\end{array}$ & $\begin{array}{l}\text { Direct measurement } \\
\text { Measurements of both } \\
\text { particle crush strength } \\
\text { and abrasion resistance } \\
\text { will be required }\end{array}$ & Material life cycle & $\begin{array}{l}\text { Degradations in mechanical stability of } 3 \mathrm{~A} \mathrm{MS} \\
\text { have not been observed in previous OGST } \\
\text { testing. }\end{array}$ \\
\hline
\end{tabular}


Table 3. Data needs for tritium sorbents—Air TPT case (continued)

\begin{tabular}{|c|c|c|c|c|c|}
\hline$\#$ & $\begin{array}{l}\text { Property } \\
\text { Units }\end{array}$ & Specific requirements & Approach & Data gap impact & Notes \\
\hline 14 & $\begin{array}{l}\text { Thermal stability } \\
\text { \% degradation in } \\
\text { capacity after } \\
\text { exposure to multiple } \\
\text { adsorption/regenera } \\
\text { tion cycles }\end{array}$ & $\begin{array}{l}\text { Determine the extent of capacity } \\
\text { loss due to extended exposure to } \\
\text { operating temperature. Determine } \\
\text { the extent of capacity loss due to } \\
\text { thermal cycling and excursions. }\end{array}$ & $\begin{array}{l}\text { Extended testing with } \\
\text { thin-bed analysis. } \\
\text { The sorbent should be } \\
\text { exposed to the operating } \\
\text { temperature for extended } \\
\text { periods of time, and } \\
\text { should experience thermal } \\
\text { cycling to simulate } \\
\text { regeneration of the } \\
\text { sorbent. The capacity } \\
\text { should be measured after } \\
\text { thermal exposure by thin- } \\
\text { bed testing. } \\
\text { (Thin-bed testing: See } \\
\text { Gap ID \#1) }\end{array}$ & Material life cycle & $\begin{array}{l}\text { Degradations in thermal stability of } 3 \mathrm{~A} \text { MS } \\
\text { have not been observed in previous OGST } \\
\text { testing, with up to } 3 \text { regeneration cycles. }\end{array}$ \\
\hline 15 & $\begin{array}{l}\text { Chemical stability } \\
\text { \% degradation in } \\
\text { capacity over time } \\
\text { as a function of } \\
\text { other species present } \\
\text { in gas stream }\end{array}$ & $\begin{array}{l}\text { Confirmation that any } \\
\text { compatibility issues can be } \\
\text { avoided through selection of } \\
\text { materials of construction, } \\
\text { appropriate pretreatment of gas } \\
\text { stream, operational envelope, etc. }\end{array}$ & $\begin{array}{l}\text { Extended testing with } \\
\text { thin-bed analysis. } \\
\text { Age sorbents for various } \\
\text { lengths of time to elevated } \\
\text { levels of each of the non- } \\
\text { target species expected. } \\
\text { Determine } \mathrm{H}_{2} \mathrm{O} \text { capacity } \\
\text { and rates of adsorption. } \\
\text { Differences should be } \\
\text { attributable to aging and } \\
\text { should be a function of } \\
\text { exposure time and non- } \\
\text { target species exposure. } \\
\text { (Thin-bed testing; See } \\
\text { Gap ID \#1) }\end{array}$ & Material life cycle & $\begin{array}{l}\text { 3A MS sorbent is chemically stable in basic, } \\
\text { neutral, and mildly acidic environments. }\end{array}$ \\
\hline
\end{tabular}


Data Requirements and Test System Needs for Development of an Integrated Off-Gas Treatment

Table 3. Data needs for tritium sorbents-Air TPT case (continued)

\begin{tabular}{|c|c|c|c|c|c|}
\hline \# & $\begin{array}{c}\text { Property } \\
\text { Units }\end{array}$ & Specific requirements & Approach & Data gap impact & Notes \\
\hline 16 & $\begin{array}{c}\text { Reactivity } \\
\text { Compatibility as } \\
\text { determined by } \\
\text { standardized } \\
\text { compatibility tables }\end{array}$ & $\begin{array}{l}\text { Demonstrated compatibility with } \\
\text { all components of gas stream and } \\
\text { materials of construction. }\end{array}$ & Direct evaluation. & Material life cycle & $\begin{array}{l}\text { 3A MS is compatible with common materials } \\
\text { of construction and is chemically stable in } \\
\text { basic, neutral, and mildly acidic environments. }\end{array}$ \\
\hline 17 & $\begin{array}{c}\text { Regeneration } \\
\text { capacity stability } \\
\% \text { degradation in } \\
\mathrm{H}_{2} \mathrm{O} \text { capacity per } 10 \\
\text { regeneration cycles }\end{array}$ & $\begin{array}{l}\text { No. of cycles before degrading to } \\
80 \% \text { of capacity for the target } \\
\text { element. }\end{array}$ & $\begin{array}{l}\text { Extended testing with } \\
\text { thin-bed analysis. } \\
\text { Long-term, repeated } \\
\text { testing of select sorbent } \\
\text { over multiple adsorption/ } \\
\text { desorption cycles if } \\
\text { sorbent is to be } \\
\text { regenerated. N/A if single } \\
\text { use. } \\
\text { (Thin-bed testing; See } \\
\text { Gap ID \#1) }\end{array}$ & Material life cycle & $\begin{array}{l}\text { OGST has obtained data measuring the } \mathrm{H}_{2} \mathrm{O} \\
\text { capacity during } 3 \text { regeneration cycles and no } \\
\text { degradation in capacity was observed. }\end{array}$ \\
\hline 18 & $\begin{array}{c}\text { Desorption rate of } \\
\qquad \mathbf{H}_{2} \mathbf{O} \\
\mathrm{mol} / \mathrm{kg} \mathrm{sorbent} / \mathrm{h} \\
\end{array}$ & $\begin{array}{l}\text { Desorption rate as a function of } \\
\text { desorption temperature and purge } \\
\text { stream gas velocity. }\end{array}$ & $\begin{array}{l}\text { Thin-bed testing. } \\
\text { (See Gap ID \#1) }\end{array}$ & $\begin{array}{l}\text { Equipment } \\
\text { size/operational } \\
\text { sequencing }\end{array}$ & $\begin{array}{l}\text { OGST has measured for a desorption } \\
\text { temperature of } 270^{\circ} \mathrm{C} \text { for a single flow rate. }\end{array}$ \\
\hline 19 & $\begin{array}{l}\text { Desorption of co- } \\
\text { adsorbed species } \\
\text { mol co-adsorbed } \\
\text { species retained/ } \mathrm{kg} \\
\text { sorbent }\end{array}$ & $\begin{array}{l}\% \text { of co-adsorbed species desorbed } \\
\text { during selected regeneration } \\
\text { conditions. } \\
\text { Species of interest, their } \\
\text { concentrations, and temperature } \\
\text { and gas velocity ranges are found } \\
\text { in Gap ID \#3. }\end{array}$ & $\begin{array}{l}\text { Thin-bed testing with } \\
\text { post-test sorbent analysis. } \\
\text { (See Gap ID \#1) }\end{array}$ & Equipment size & \\
\hline
\end{tabular}


Table 3. Data needs for tritium sorbents-Air TPT case (continued)

\begin{tabular}{|c|c|c|c|c|c|}
\hline \# & $\begin{array}{l}\text { Property } \\
\text { Units }\end{array}$ & Specific requirements & Approach & Data gap impact & Notes \\
\hline 20 & $\begin{array}{c}\begin{array}{c}\text { Desorption rate of } \\
\text { co-adsorbed species } \\
\mathrm{mol} / \mathrm{m}^{3} / \mathrm{h}\end{array}\end{array}$ & $\begin{array}{l}\text { Desorption rate of co-adsorbed } \\
\text { species as a function of } \\
\text { temperature and gas velocity. } \\
\text { Species of interest, their } \\
\text { concentrations, and temperature } \\
\text { and gas velocity ranges are found } \\
\text { in Gap ID \#3. }\end{array}$ & $\begin{array}{l}\text { Thin-bed testing with } \\
\text { time-resolved sorbent } \\
\text { analysis. } \\
\text { (See Gap ID \#6) }\end{array}$ & Material life cycle & \\
\hline 21 & $\begin{array}{c}\begin{array}{c}\text { Purity of } \\
\text { condensate }\end{array} \\
\text { mol impurity/kg }{ }^{3} \mathrm{H}- \\
\text { bearing condensate }\end{array}$ & $\begin{array}{l}\text { The level of impurities tolerated is } \\
\text { determined by the waste } \\
\text { acceptance criteria for the intended } \\
\text { disposition facility. }\end{array}$ & $\begin{array}{l}\text { Deep-bed testing with } \\
\text { condensation of desorbed } \\
\mathrm{H}_{2} \mathrm{O} \text { and condensate } \\
\text { analysis. }\end{array}$ & Equipment size & \\
\hline 22 & $\begin{array}{c}\text { Cooling time } \\
h\end{array}$ & $\begin{array}{l}\text { Hours to cool from regeneration } \\
\text { temperature }\left(270^{\circ} \mathrm{C}\right) \text { to adsorbing } \\
\text { temperature }\left(30^{\circ} \mathrm{C}\right) .\end{array}$ & $\begin{array}{l}\text { Derived from heat } \\
\text { capacity, thermal } \\
\text { conductivity, and bed } \\
\text { design. }\end{array}$ & Heat duty & \\
\hline \multicolumn{6}{|c|}{ Metrics for system design and performance criterion } \\
\hline 23 & $\begin{array}{c}\text { Pressure drop } \\
P a / m v s m^{2} \text { column }\end{array}$ & $\begin{array}{l}\text { Pressure drop as a function of } \\
\text { column length. }\end{array}$ & $\begin{array}{l}\text { Direct measurement (or } \\
\text { scaled derivation). }\end{array}$ & Equipment size & \\
\hline
\end{tabular}


Data Requirements and Test System Needs for Development of an Integrated Off-Gas Treatment

Table 3. Data needs for tritium sorbents-Air TPT case (continued)

\begin{tabular}{|c|c|c|c|c|c|}
\hline \# & $\begin{array}{l}\text { Property } \\
\text { Units }\end{array}$ & Specific requirements & Approach & Data gap impact & Notes \\
\hline 24 & $\begin{array}{c}\begin{array}{c}\text { Decontamination } \\
\text { factor }(\mathbf{D F})\end{array} \\
{[\text { Isotope }]_{a} /[\text { Isotope }]_{b}} \\
{\left[\mathrm{H}_{2} \mathrm{O}\right]_{\text {inlet }} /\left[\mathrm{H}_{2} \mathrm{O}\right]_{\text {outlet }}} \\
\text { (unitless) }\end{array}$ & $\begin{array}{l}\text { DF data as function of } \mathrm{H}_{2} \mathrm{O} \\
\text { concentration, time, bed depth and } \\
\text { gas velocity. } \\
\text { Recommended experimental } \\
\text { ranges are found in Gap ID \#1. } \\
\begin{array}{l}\text { DF requirements will be design } \\
\text { dependent. }\end{array}\end{array}$ & $\begin{array}{l}\text { Deep-bed testing with } \\
\text { online measurement of } \\
\text { inlet and effluent } \mathrm{H}_{2} \mathrm{O} \\
\text { concentrations. } \\
\text { Test system must be able } \\
\text { to hold a deep bed of } \\
\text { sorbent at given } \\
\text { temperature and expose } \\
\text { sorbent to a generated air } \\
\text { stream containing water } \\
\text { (and any potentially co- } \\
\text { adsorbed species) at } \\
\text { varying concentrations } \\
\text { within the specified } \\
\text { concentration range and } \\
\text { gas velocity. Both inlet } \\
\text { and effluent gas streams } \\
\text { must be assessed for } \mathrm{H}_{2} \mathrm{O} \\
\text { concentration. }\end{array}$ & Equipment size & $\begin{array}{l}\text { OGST has collected DF data for a limited } \\
\text { condition set. }\end{array}$ \\
\hline
\end{tabular}


Data Requirements and Test System Needs for Development of an Integrated Off-Gas Treatment System

Table 3. Data needs for tritium sorbents—Air TPT case (continued)

\begin{tabular}{|c|c|c|c|c|c|}
\hline$\#$ & $\begin{array}{l}\text { Property } \\
\text { Units }\end{array}$ & Specific requirements & Approach & Data gap impact & Notes \\
\hline 25 & $\begin{array}{c}\text { Length of Mass } \\
\text { Transfer Zone } \\
\text { (MTZ) } \\
m\end{array}$ & $\begin{array}{l}\text { Length of } \mathrm{MTZ} \text { as a function of } \\
\text { gas velocity, } \mathrm{H}_{2} \mathrm{O} \text { concentration, } \\
\text { and presence of co-absorbed } \\
\text { species shown to have impact on } \\
\text { total capacity or adsorption rate }> \\
10 \% \text {. } \\
\text { Recommended experimental } \\
\text { ranges are found in Gap ID \#1. }\end{array}$ & $\begin{array}{l}\text { Deep-bed testing with } \\
\text { online measurement of } \\
\text { inlet and effluent } \mathrm{H}_{2} \mathrm{O} \\
\text { concentrations. } \\
\text { Test system must be able } \\
\text { to hold a deep bed of } \\
\text { sorbent at given } \\
\text { temperature and expose } \\
\text { sorbent to a generated air } \\
\text { stream containing water } \\
\text { (and any potentially co- } \\
\text { adsorbed species) at } \\
\text { varying concentrations } \\
\text { within the specified } \\
\text { concentration range and } \\
\text { gas velocity. }\end{array}$ & Equipment size & $\begin{array}{l}\text { OGST has collected MTZ data for a limited } \\
\text { condition set. }\end{array}$ \\
\hline
\end{tabular}




\section{3 lodine recovery systems}

Radioactive iodine capture could be one of the more challenging volatile or semi-volatile radionuclides requiring abatement. ${ }^{129}$ I could be present in multiple off-gas streams (including the DOG, VOG, and air TPT streams), may present as different gas species, and may be present at concentrations that could vary by orders of magnitude. Relatively high iodine removal efficiencies are expected to be required. The different expected off-gas streams could have flow rates that vary by orders of magnitude from each other. These conditions dictate a highly efficient iodine capture technology that can be adapted in different sorption designs tailored for different off-gas systems with different gas flow rates and compositions. Current Department of Energy R\&D activities focus on solid silver-based iodine sorbents. Iodine adsorption research is currently being performed using both thin-bed and deep-bed test systems at Oak Ridge National Laboratory (ORNL) and Idaho National Laboratory, and the data from that testing and past work was reflected in the Engineering Evaluation. This experience base and data are accounted for by the authors in the preparation of the iodine adsorption data gap tables. Although a substantial amount of data is available relating to iodine abatement by silver sorbents, the majority of this data has been collected at conditions relevant to the DOG, and iodine removal from the VOG or air TPT streams is notably less understood.

Table 4 summarizes the data gaps for iodine adsorption processes for DOG systems. Table 5 summarizes data gaps for the VOG and air TPTOG systems, which are expected to have iodine concentrations about two orders of magnitude lower than in DOG systems. The extremely dilute iodine concentrations of the VOG and air TPT present a substantial challenge for iodine abatement compared to the DOG. The VOG and air TPT streams may have similar iodine concentrations, but the iodine speciation is very different, with iodine in the air TPTOG expected to be primarily elemental $\mathrm{I}_{2}$ and in the VOG expected to be a mixture of various organic iodides. The need to achieve high removal efficiencies for such lowconcentration gas streams, together with the much higher expected VOG system flow rate and iodine species, could impose different sorbent system design and operating requirements. These different performance requirements dictate some differences in how $R \& D$ activities relating to iodine capture from VOG and air TPT streams need to be tailored compared to R\&D on iodine capture from DOG streams.

Recommended experimental systems for both DOG and VOG/air TPT are primarily thin- and deep-bed test systems. Thin-bed testing is beneficial for determining the iodine capture capacity and rate because these parameters can be measured in real time when the thin-bed system is inside a TGA. Deep-bed testing is necessary to determine capture efficiency and the length of the MTZ. However, the lower expected iodine concentrations in VOG and air TPTOG streams dictates much longer-duration testing, which challenges the ability to operate both thin-bed TGA and deep-bed test systems stably to produce the needed data. Further, extremely dilute iodine concentrations may limit the applicability of thin-bed and TGA testing for VOG/air TPT experiments.

The highest priority data gaps for iodine recovery systems are the DF (Gap \#24) and length of the MTZ (Gap \#25). Values for DF as well as estimates for the length of the MTZ are available for some DOG conditions, but there is little relevant information available for VOG and air TPT systems. The MTZ depth and the DF were explicitly discussed in the Engineering Evaluation as being of high importance in the off-gas abatement system design process. Determination of these parameters in the cases of VOG and air TPT could require tests on the time order of months or years.

A similar priority data need is the continuing collection of basic adsorption performance data for VOG and air TPT systems (Gap IDs \#1-2). This information has been collected for DOG systems over selected experimental ranges. To accurately resolve Gaps \#1-2 for VOG/air TPT, longer term tests will need to be carried out, and a prototype of this testing was initiated in fiscal year 2017 at ORNL.

The next tier of data gaps is the determination of the impact of co-adsorbed species on iodine capture (Gaps \#3-7). This includes the concentration of contaminants expected to adsorb onto the iodine capture 
material and determination of whether those species would depress the iodine capture rate or capacity. This information would require thin- and deep-bed tests. Gaps \#3-7 have been investigated for DOG systems, but almost no information is available for VOG/air TPT systems.

The third tier of data gaps is the desorption behavior both of iodine and co-adsorbed species (Gaps \#1921). There will be no regeneration of sorbent material, but physisorbed iodine will need to be removed before sorbent changeout. This data gap applies to all iodine abatement systems.

The data gaps regarding the thermal properties are considered a lower priority at this time. Finally, the data gaps that address the regeneration of the sorbent are currently the lowest priority because the iodine sorbent is currently considered a one-time use material. 
Table 4. Data gaps for DOG iodine sorbent evaluations

\begin{tabular}{|c|c|c|c|c|c|}
\hline \# & $\begin{array}{c}\text { Property } \\
\text { Units }\end{array}$ & Specific requirements & Approach & Data gap impact & Notes \\
\hline \multicolumn{6}{|c|}{ Metrics for technical performance and physical and chemical characteristics criterion } \\
\hline 1 & $\begin{array}{c}\text { Adsorption } \\
\text { Capacity } \\
\text { mol/kg sorbent }\end{array}$ & 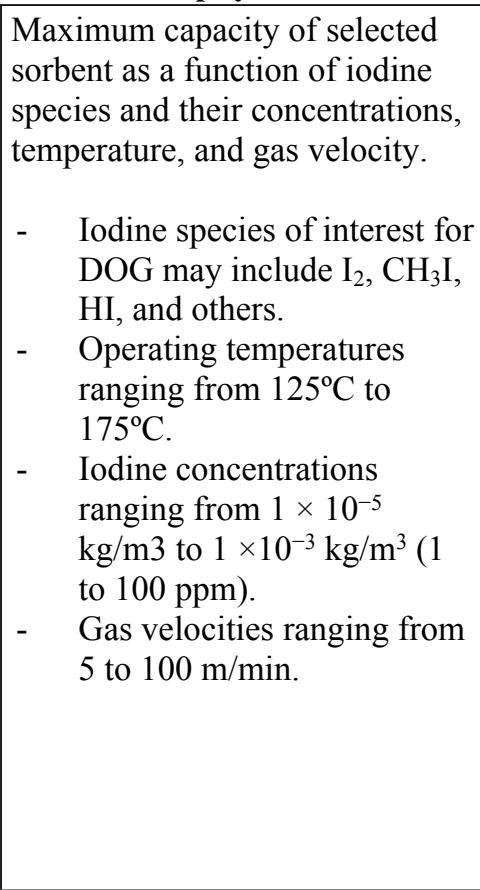 & $\begin{array}{l}\text { Thin-bed tests using } \\
\text { selected sorbent; and } \\
\text { deep-bed tests for } \\
\text { conditions at time of } \\
\text { breakthrough. } \\
\text { Test systems must be able } \\
\text { to hold thin and deep beds } \\
\text { of sorbent at given } \\
\text { temperature and expose } \\
\text { sorbent to a generated air } \\
\text { stream containing water } \\
\text { (and any potentially co- } \\
\text { adsorbed species) at } \\
\text { varying concentrations } \\
\text { within the specified } \\
\text { concentration range and } \\
\text { gas velocity. } \\
\text { Sorbents should be } \\
\text { analyzed after testing to } \\
\text { confirm iodine loading }\end{array}$ & Equipment size & $\begin{array}{l}\text { Capacity data exist for } \mathrm{AgZ} \text {, and } \mathrm{Ag} \text {-Aerogel at } \\
\text { various temperatures, typically at } 10 \mathrm{~m} / \mathrm{min} \text {. gas } \\
\text { velocity. }\end{array}$ \\
\hline 2 & $\begin{array}{l}\text { Capture/removal } \\
\text { rates for primary } \\
\text { species } \\
\text { mol/kg sorbent/h }\end{array}$ & $\begin{array}{l}\text { Adsorption rate data for selected } \\
\text { sorbent as function iodine } \\
\text { species and their concentrations, } \\
\text { temperature, and gas velocity. } \\
\text { Recommended experimental } \\
\text { ranges and iodine species are } \\
\text { found in Gap ID \#1. }\end{array}$ & $\begin{array}{l}\text { Thin-bed testing } \\
\text { (See Gap ID \#1) }\end{array}$ & Equipment size & $\begin{array}{l}\text { Data exist for } \mathrm{AgZ}, \mathrm{Ag} \text {-Aerogel, and } \mathrm{AgA} \text { at } \\
\text { various temperatures, typically at } 10 \mathrm{~m} / \mathrm{min} \text {. gas } \\
\text { velocity. }\end{array}$ \\
\hline
\end{tabular}


Table 4. Data gaps for DOG iodine sorbent evaluations (continued)

\begin{tabular}{|c|c|c|c|c|c|}
\hline \# & $\begin{array}{c}\text { Property } \\
\text { Units }\end{array}$ & Specific Requirements & Approach & Data Gap Impact & Notes \\
\hline 3 & $\begin{array}{l}\text { Capacity for other } \\
\text { species present in } \\
\text { gas stream } \\
\mathrm{mol} / \mathrm{kg} \text { sorbent }\end{array}$ & $\begin{array}{l}\text { Maximum capacity for potential } \\
\text { co-absorbed species by selected } \\
\text { sorbent material as a function of } \\
\text { species, temperature, and } \\
\text { concentration. } \\
\text { - } \\
\text { Species of interest for } \mathrm{DOG} \\
\text { may include } \mathrm{H}_{2} \mathrm{O}, \mathrm{HNO}_{3} \text {, } \\
\mathrm{CO}_{2}, \mathrm{Cl} \text {, and } \mathrm{Br} \text {, } \\
\mathrm{H}_{2} \mathrm{O} \text { with a dew point of } 0 \\
\text { to } 40^{\circ} \mathrm{C} \text {; } \\
\mathrm{HNO} \mathrm{O}_{3} \text { concentrations } \\
\text { from } 0 \text { to } 1000 \text { ppm; } \\
\mathrm{CO} \mathrm{O}_{2} \text { concentrations from } \\
0 \text { to } 440 \text { ppm; } \\
\mathrm{Cl} \text { concentrations } \\
\text { dependent on its plant acid } \\
\text { concentration } \\
\text { Br concentrations from } 1- \\
100 \text { ppm } \\
\\
\text { Operating temperatures } \\
\text { ranging from } 125^{\circ} \mathrm{C} \text { to } \\
175^{\circ} \mathrm{C} \text {. } \\
\text { Gas velocities ranging from } \\
5 \text { to } 100 \text { m/min. }\end{array}$ & $\begin{array}{l}\text { Thin-bed testing } \\
\text { (See Gap ID \#1) }\end{array}$ & Equipment size & $\begin{array}{l}\text { Information is available for water and } \mathrm{NO}_{\mathrm{x}} \text { from } \\
\text { thin-bed tests. Additional limited data are } \\
\text { available from the Coupled End-to-End } \\
\text { Research Project (CETE). }\end{array}$ \\
\hline 4 & $\begin{array}{c}\text { Capture/removal } \\
\text { rate for co-absorbed } \\
\text { species } \\
\mathrm{mol} / \mathrm{kg} \text { sorbent } / \mathrm{h}\end{array}$ & $\begin{array}{l}\text { Adsorption rate data for selected } \\
\text { sorbent as function of co- } \\
\text { absorbed species, their } \\
\text { concentrations, temperature, and } \\
\text { gas velocity. } \\
\\
\text { Recommended experimental } \\
\text { ranges and potentially co- } \\
\text { adsorbing species are provided } \\
\text { in Gap ID \#3 }\end{array}$ & $\begin{array}{l}\text { Thin-bed testing } \\
\text { (See Gap ID \#1) }\end{array}$ & Equipment size & $\begin{array}{l}\text { Information is available for water and } \mathrm{NO}_{\mathrm{x}} \text { from } \\
\text { thin-bed tests. Additional limited data are } \\
\text { available from the CETE. }\end{array}$ \\
\hline
\end{tabular}


Table 4. Data gaps for DOG iodine sorbent evaluations (continued)

\begin{tabular}{|c|c|c|c|c|c|}
\hline \# & $\begin{array}{c}\text { Property } \\
\text { Units } \\
\end{array}$ & Specific Requirements & Approach & Data Gap Impact & Notes \\
\hline 5 & $\begin{array}{l}\text { Change in sorbent } \\
\text { capacity for iodine } \\
\text { in presence of other } \\
\text { species present in } \\
\text { gas stream } \\
\mathrm{mol} / \mathrm{kg} \text { sorbent }\end{array}$ & $\begin{array}{l}\text { Iodine capacity of selected } \\
\text { sorbent material in the presence } \\
\text { of co-absorbed species as a } \\
\text { function of species, temperature, } \\
\text { and concentration. } \\
\text { Recommended experimental } \\
\text { ranges, iodine species, and } \\
\text { potentially co-adsorbing species } \\
\text { are provided in Gap IDs \#1 and } \\
3 .\end{array}$ & $\begin{array}{l}\text { Thin-bed testing with } \\
\text { post-adsorption sorbent } \\
\text { analysis. } \\
\text { Thin-bed testing (see Gap } \\
\text { ID \#1) using selected } \\
\text { sorbent followed by } \\
\text { chemical or gamma } \\
\text { analysis of sorbent }\end{array}$ & Equipment size & $\begin{array}{l}\text { Information is available for water and } \mathrm{NO}_{\mathrm{x}} \text { from } \\
\text { thin-bed tests. Additional limited data are } \\
\text { available from the CETE. }\end{array}$ \\
\hline 6 & $\begin{array}{l}\text { Change in iodine } \\
\text { capture rate in } \\
\text { presence of co- } \\
\text { absorbed species } \\
\mathrm{mol} / \mathrm{kg} \text { sorbent } / \mathrm{h}\end{array}$ & $\begin{array}{l}\text { Iodine adsorption rate data for } \\
\text { selected sorbent as function of } \\
\text { co-absorbed species, } \\
\text { temperature, and concentration. } \\
\text { Recommended experimental } \\
\text { ranges, iodine species, and } \\
\text { potentially co-adsorbing species } \\
\text { are provided in Gap IDs \#1 and } \\
3 \text {. }\end{array}$ & $\begin{array}{l}\text { Thin-bed testing. } \\
\text { (See Gap ID \#1) }\end{array}$ & Equipment size & $\begin{array}{l}\text { Information is available for water and } \mathrm{NO}_{\mathrm{x}} \text { from } \\
\text { thin-bed tests. Additional limited data are } \\
\text { available from the CETE. }\end{array}$ \\
\hline 7 & $\begin{array}{c}\text { Selectivity } \\
\left(X_{a} / Y_{a}\right) /\left(X_{b} / Y_{b}\right) \\
\text { (unitless) } \\
\text { Where } X_{a} \text { and } X_{b} \text { are } \\
\text { mol fractions of } \\
\text { species a and } b \\
\text { respectively in the } \\
\text { adsorbed phase, and } \\
Y_{a} \text { and } Y_{b} \text { are mol } \\
\text { fractions of species a } \\
\text { and } b \text { in the bulk }\end{array}$ & Derived from Gap ID \#3-6. & $\begin{array}{l}\text { Thin-bed testing with } \\
\text { post-adsorption sorbent } \\
\text { analysis. } \\
\text { (See Gap ID \#5) }\end{array}$ & Equipment size & $\begin{array}{l}\text { Derived from data on co-absorption studies } \\
\text { shown above. Limited data are available from } \\
\text { the CETE. } \\
\text { Should include information on general co- } \\
\text { adsorbents (such as } \mathrm{NO}_{\mathrm{x}} \text { and water), or with } \\
\text { tramp halogens (chlorine, bromine, fluorine). }\end{array}$ \\
\hline
\end{tabular}


Table 4. Data gaps for DOG iodine sorbent evaluations (continued)

\begin{tabular}{|c|c|c|c|c|c|}
\hline \# & $\begin{array}{l}\text { Property } \\
\text { Units }\end{array}$ & Specific Requirements & Approach & Data Gap Impact & Notes \\
\hline & phase & & & & \\
\hline 8 & $\begin{array}{c}\begin{array}{c}\text { Sorbent particle } \\
\text { density }\end{array} \\
\mathrm{kg} / \mathrm{m}^{3}\end{array}$ & $\begin{array}{l}\text { Density of individual particles in } \\
\mathrm{kg} / \mathrm{m}^{3} \text {. }\end{array}$ & $\begin{array}{l}\text { Direct measurement or } \\
\text { from manufacturer. }\end{array}$ & Equipment size & \\
\hline 9 & $\begin{array}{c}\begin{array}{c}\text { Sorbent bulk } \\
\text { density }\end{array} \\
\mathrm{kg} / \mathrm{m}^{3} \\
\end{array}$ & $\begin{array}{l}\text { Bulk density of bed of sorbent } \\
\text { material in typical loading } \\
\text { configuration in } \mathrm{kg} / \mathrm{m}^{3} \text {. }\end{array}$ & $\begin{array}{l}\text { Direct measurement or } \\
\text { from manufacturer. }\end{array}$ & Equipment size & \\
\hline 10 & $\begin{array}{c}\begin{array}{c}\text { Specific heat } \\
\text { capacity }\end{array} \\
\mathrm{J} / \mathrm{K} / \mathrm{kg} \\
\end{array}$ & $\begin{array}{l}\text { Specific heat capacity of fresh } \\
\text { and loaded sorbent from } 25^{\circ} \mathrm{C}- \\
300^{\circ} \mathrm{C}\end{array}$ & $\begin{array}{l}\text { Direct measurement of } \\
\text { fresh sorbent and loaded } \\
\text { sorbent. }\end{array}$ & Heat duty & \\
\hline 11 & $\begin{array}{c}\begin{array}{c}\text { Thermal } \\
\text { conductivity }\end{array} \\
W / m / K\end{array}$ & $\begin{array}{l}\text { Thermal conductivity of fresh } \\
\text { and loaded sorbent from } 25^{\circ} \mathrm{C}- \\
300^{\circ} \mathrm{C} \text {. }\end{array}$ & $\begin{array}{l}\text { Direct measurement of } \\
\text { fresh sorbent and loaded } \\
\text { sorbent. }\end{array}$ & Heat duty & \\
\hline 12 & $\begin{array}{l}\text { Radiation stability } \\
\\
\% \text { degradation in } \\
\text { capacity, adsorption } \\
\text { rate, regeneration } \\
\text { time, and MTZ over } \\
\text { time as a function of } \\
\text { radiation exposure }\end{array}$ & $\begin{array}{l}\text { Capacity for iodine and iodine } \\
\text { adsorption rate as a function of } \\
\text { adsorbed dose. } \\
\text { Total dose requirement is design } \\
\text { dependent. } \\
\text { Total dose should factor in both } \\
\text { external dose and internal dose. }\end{array}$ & $\begin{array}{l}\text { Irradiation and thin-bed } \\
\text { testing. } \\
\text { Exposure of the sorbent to } \\
\text { both } \gamma \text { and } \beta \text { radiation for } \\
\text { a range of total doses. } \\
\text { Testing of the sorbent with } \\
\text { both thin- and deep-bed } \\
\text { testing to characterize } \\
\text { radiation effects. } \\
\text { (Thin-bed testing: See } \\
\text { Gap IDs \#1 and \#5) }\end{array}$ & Material life cycle & \\
\hline 13 & $\begin{array}{c}\text { Mechanical stability } \\
\text { N/mm (load vs } \\
\text { particle diameter) }\end{array}$ & $\begin{array}{l}\text { Determination of the fines } \\
\text { generation and mechanical } \\
\text { strength of the sorbent material. }\end{array}$ & $\begin{array}{l}\text { Direct measurement. } \\
\text { Measurements of both } \\
\text { particle crush strength } \\
\text { and abrasion resistance }\end{array}$ & Material life cycle & $\begin{array}{l}\text { Previous tests have indicated that Ag-Aerogel } \\
\text { could generate fines under some off-gas } \\
\text { conditions; AgZ appears to be stable. }\end{array}$ \\
\hline
\end{tabular}


Data Requirements and Test System Needs for Development of an Integrated Off-Gas Treatment

Table 4. Data gaps for DOG iodine sorbent evaluations (continued)

\begin{tabular}{|c|c|c|c|c|c|}
\hline \# & $\begin{array}{c}\text { Property } \\
\text { Units }\end{array}$ & Specific Requirements & Approach & Data Gap Impact & Notes \\
\hline & $\begin{array}{l}\mu g / m^{3} \text { loss to gas } \\
\text { stream }\end{array}$ & & will be required & & \\
\hline 14 & $\begin{array}{l}\text { Thermal stability } \\
\text { \% degradation in } \\
\text { capacity over time at } \\
\text { selected operating } \\
\text { temperature }\end{array}$ & $\begin{array}{l}\text { Determine the extent of capacity } \\
\text { loss due to extended exposure to } \\
\text { operating temperature. } \\
\text { Determine the extent of capacity } \\
\text { loss due to thermal excursions. }\end{array}$ & $\begin{array}{l}\text { Thin-bed testing. } \\
\text { (See Gap ID \#1) }\end{array}$ & Material life cycle & $\begin{array}{l}\text { Previous tests have not resulted in appreciable } \\
\text { thermal instability over time intervals for AgZ } \\
\text { lifetime in DOG systems }\end{array}$ \\
\hline 15 & $\begin{array}{l}\text { Chemical stability } \\
\% \text { degradation in } \\
\text { capacity over time as } \\
\text { a function of other } \\
\text { species present in gas } \\
\text { stream }\end{array}$ & $\begin{array}{l}\text { Determine the degradation in } \\
\text { sorption performance (capacity, } \\
\text { rate, etc.) as a function of } \\
\text { contaminants in the gas feed } \\
\text { system (e.g., } \mathrm{NO}_{\mathrm{x}} \text {, tramp } \\
\text { halogens, etc.). }\end{array}$ & $\begin{array}{l}\text { Thin-bed testing. } \\
\text { (See Gap ID \#1) }\end{array}$ & Material life cycle & \\
\hline 16 & $\begin{array}{c}\text { Reactivity } \\
\text { Compatibility as } \\
\text { determined by } \\
\text { standardized } \\
\text { compatibility tables }\end{array}$ & $\begin{array}{l}\text { Confirmation that any } \\
\text { compatibility issues can be } \\
\text { avoided through selection of } \\
\text { materials of construction, } \\
\text { appropriate pretreatment of gas } \\
\text { stream, operational envelope, } \\
\text { etc. }\end{array}$ & Direct evaluation. & Material life cycle & $\begin{array}{l}\text { AgZ appears to be compatible with all elements } \\
\text { of the system. }\end{array}$ \\
\hline 17 & $\begin{array}{c}\text { Regeneration } \\
\text { capacity stability } \\
\text { \% initial capacity vs. } \\
\text { cycle }\end{array}$ & $\begin{array}{l}\% \text { degradation as a function of } \\
\text { regeneration temperature and } \\
\text { duration. This is not applicable } \\
\text { for Ag-based iodine adsorbents; } \\
\text { one-time use only. }\end{array}$ & $\mathrm{N} / \mathrm{A}$ & $\mathrm{N} / \mathrm{A}$ & $\begin{array}{l}\text { Not currently considered a factor for iodine } \\
\text { sorbents as these are most likely one time use. }\end{array}$ \\
\hline 18 & $\begin{array}{c}\text { Desorption rate of } \\
\text { iodine during post } \\
\text { loading purge } \\
\mathrm{mol} / \mathrm{kg} \mathrm{sorbent/h}\end{array}$ & $\begin{array}{l}\text { Desorption of iodine as a } \\
\text { function of operating } \\
\text { temperature and purge gas } \\
\text { velocity. } \\
\text { - Operating temperatures } \\
\text { ranging from } 125^{\circ} \mathrm{C} \text { to } \\
\end{array}$ & $\begin{array}{l}\text { Thin-bed testing. } \\
\text { (See Gap ID \#1) }\end{array}$ & $\begin{array}{l}\text { Operational } \\
\text { sequencing }\end{array}$ & $\begin{array}{l}\text { Some data are available for existing AgZ and } \\
\text { Ag-Aerogel sorbent from thin- and deep-bed } \\
\text { testing }\end{array}$ \\
\hline
\end{tabular}


Table 4. Data gaps for DOG iodine sorbent evaluations (continued)

\begin{tabular}{|c|c|c|c|c|c|}
\hline \# & $\begin{array}{c}\text { Property } \\
\text { Units }\end{array}$ & Specific Requirements & Approach & Data Gap Impact & Notes \\
\hline & & 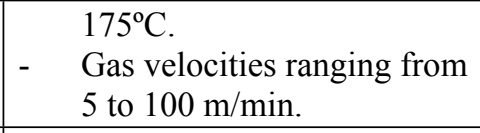 & & & \\
\hline 19 & $\begin{array}{l}\text { Desorption of co- } \\
\text { adsorbed species } \\
\text { mol co-adsorbed } \\
\text { species retained/ } \mathrm{kg} \\
\text { sorbent }\end{array}$ & $\begin{array}{l}\text { \% of co-adsorbed species } \\
\text { desorbed during selected } \\
\text { regeneration conditions. } \\
\text { Recommended experimental } \\
\text { ranges and potentially co- } \\
\text { adsorbing species are provided } \\
\text { in Gap ID \#3. }\end{array}$ & $\begin{array}{l}\text { Thin- and deep-bed } \\
\text { testing. } \\
\text { (See Gap ID \#1) }\end{array}$ & $\begin{array}{l}\text { Equipment } \\
\text { size/material life } \\
\text { cycle }\end{array}$ & \\
\hline 20 & $\begin{array}{c}\text { Desorption rate of } \\
\text { co-adsorbed species } \\
\mathrm{mol} / \mathrm{kg} \mathrm{sorbent} / \mathrm{h}\end{array}$ & $\begin{array}{l}\text { Desorption rate as a function of } \\
\text { desorption temperature and } \\
\text { purge stream gas velocity. } \\
\text { Recommended experimental } \\
\text { ranges and potentially co- } \\
\text { adsorbing species are provided } \\
\text { in Gap ID \#3. }\end{array}$ & $\begin{array}{l}\text { Thin- and deep-bed } \\
\text { testing. } \\
\text { (See Gap ID \#1) }\end{array}$ & Material life cycle & \\
\hline 21 & $\begin{array}{c}\text { Purity of desorbed } \\
\text { iodine streams } \\
\text { ppm or \% iodine }\end{array}$ & $\begin{array}{l}\text { Prescribed by waste treatment } \\
\text { operation. }\end{array}$ & $\begin{array}{l}\text { Purge of deep beds used } \\
\text { in previous tests with gas } \\
\text { analysis. }\end{array}$ & $\begin{array}{l}\text { Equipment size } \\
\text { and waste } \\
\text { treatment process } \\
\text { design }\end{array}$ & Sizing of downstream processes \\
\hline 22 & $\begin{array}{c}\text { Cooling time } \\
h\end{array}$ & $\begin{array}{l}\text { Hours to cool from pretreatment } \\
\text { temperature }\left(270^{\circ} \mathrm{C}\right) \text { to } \\
\text { adsorbing temperature }\left(150^{\circ} \mathrm{C}\right) \\
\text { and to ambient temperature after } \\
\text { purge. }\end{array}$ & $\begin{array}{l}\text { Derived from heat } \\
\text { capacity, thermal } \\
\text { conductivity, and bed } \\
\text { design. }\end{array}$ & $\mathrm{N} / \mathrm{A}$ & $\begin{array}{l}\text { Readily derived and confirmed during deep-bed } \\
\text { testing. }\end{array}$ \\
\hline \multicolumn{6}{|c|}{ Metrics for system design and performance criterion } \\
\hline 23 & $\begin{array}{c}\text { Pressure drop } \\
\text { Pa/m vs } m^{2} \text { column }\end{array}$ & $\begin{array}{c}\text { Size columns and sorbent size } \\
\text { for }<2.5 \mathrm{kPa} \text { pressure drop based } \\
\text { on expected gas flow rates }\end{array}$ & $\begin{array}{l}\text { Direct measurement or } \\
\text { scaled derivation }\end{array}$ & $\begin{array}{l}\text { Operational } \\
\text { sequencing/equip } \\
\text { ment size }\end{array}$ & \\
\hline 24 & $\begin{array}{l}\text { Decontamination } \\
\text { factor (DF) }\end{array}$ & $\begin{array}{l}\text { DF data as function of sorbent, } \\
\text { iodine species, their } \\
\text { concentrations, temperature, and }\end{array}$ & $\begin{array}{l}\text { Deep-bed testing with } \\
\text { online measurement of } \\
\text { inlet and effluent iodine }\end{array}$ & Equipment size & $\begin{array}{l}\text { DFs exist for } \mathrm{I}_{2} \text { and methyl iodide adsorption on } \\
\text { AgZ and Ag-Aerogel for selected, limited test } \\
\text { conditions; have been for reported for higher- }\end{array}$ \\
\hline
\end{tabular}


Data Requirements and Test System Needs for Development of an Integrated Off-Gas Treatment

Table 4. Data gaps for DOG iodine sorbent evaluations (continued)

\begin{tabular}{|c|c|c|c|c|c|}
\hline \# & $\begin{array}{c}\text { Property } \\
\text { Units }\end{array}$ & Specific Requirements & Approach & Data Gap Impact & Notes \\
\hline & $\begin{array}{l}{[I]_{\text {inlet }} /[I]_{\text {outlet }}} \\
\text { (unitless) }\end{array}$ & $\begin{array}{l}\text { bed depth. } \\
\text { Recommended experimental } \\
\text { ranges and iodine species are } \\
\text { provided in Gap ID \#1. }\end{array}$ & $\begin{array}{l}\text { concentrations. } \\
\text { Test system must be able } \\
\text { to hold a deep bed of } \\
\text { sorbent at given } \\
\text { temperature and expose } \\
\text { sorbent to a generated air } \\
\text { stream containing water } \\
\text { (and any potentially co- } \\
\text { adsorbed species) at } \\
\text { varying concentrations } \\
\text { within the specified } \\
\text { concentration range and } \\
\text { gas velocity. Both inlet } \\
\text { and effluent gas streams } \\
\text { must be assessed for } \\
\text { iodine concentration. } \\
\end{array}$ & & concentration $\left(\sim 1 \times 10^{3} \mathrm{ppm}\right)$ iodine systems \\
\hline 25 & $\begin{array}{c}\text { Length of Mass } \\
\text { Transfer Zone } \\
\text { (MTZ) } \\
m\end{array}$ & $\begin{array}{l}\text { Length of MTZ as a function of } \\
\text { gas velocity, target species } \\
\text { concentration, temperature, and } \\
\text { presence of co-absorbed species } \\
\text { shown to have impact on total } \\
\text { capacity or adsorption rate } \\
>10 \% \text {. } \\
\text { Recommended experimental } \\
\text { ranges and iodine species are } \\
\text { provided in Gap ID \#1. }\end{array}$ & $\begin{array}{l}\text { Deep-bed tests with bed } \\
\text { depth that captures } 1.5 \\
\text { times MTZ. Predictions } \\
\text { can be made from thin- } \\
\text { bed tests and data may } \\
\text { also be determined from } \\
\text { DF testing using deep } \\
\text { beds. } \\
\text { (Deep-bed testing: Gap } \\
\text { ID \#24). }\end{array}$ & Equipment size & $\begin{array}{l}\text { Estimates of length of MTZ exist for } \mathrm{I}_{2} \text { and } \\
\text { methyl iodide adsorption on } \mathrm{AgZ} \text { and } \mathrm{Ag}- \\
\text { Aerogel for selected, limited test conditions. }\end{array}$ \\
\hline
\end{tabular}


Table 5. Data gaps for iodine sorbent evaluations for air TPT and VOG gas streams

\begin{tabular}{|c|c|c|c|c|c|}
\hline \# & Property & Specific requirements & Approach & Data gap impact & Notes \\
\hline \multicolumn{6}{|c|}{ Metrics for technical performance and physical and chemical characteristics criterion } \\
\hline 1 & $\begin{array}{c}\begin{array}{c}\text { Adsorption } \\
\text { capacity }\end{array} \\
\text { mol/kg sorbent }\end{array}$ & $\begin{array}{l}\text { Maximum capacity of selected } \\
\text { sorbent as a function of iodine } \\
\text { species and their concentrations, } \\
\text { temperature, and gas velocity. } \\
\text { - } \quad \text { Iodine species of interest for } \\
\text { VOG may include } \mathrm{I}_{2}, \mathrm{CH}_{3} \mathrm{I}, \\
\text { and various organic iodides. } \\
\text { For air TPT iodine is } \\
\text { expected to be } \mathrm{I}_{2} \text {. } \\
\text { Operating temperatures } \\
\text { ranging from } 25^{\circ} \mathrm{C} \text { to } 175^{\circ} \mathrm{C} \text {. } \\
\text { Iodine concentrations } \\
\text { ranging from } 1 \times 10^{-55} \mathrm{~kg} / \mathrm{m}^{3} \\
\text { to } 1 \times 10^{-7} \mathrm{~kg} / \mathrm{m}^{3} \text { (from } 0.1 \mathrm{to} \\
1 \text { ppm). } \\
\text { Gas velocities ranging from } \\
5 \text { to } 100 \mathrm{~m} / \mathrm{min}^{2}\end{array}$ & $\begin{array}{l}\text { Extended-duration thin- } \\
\text { bed or hybrid thin-deep } \\
\text { bed testing. } \\
\text { Test system must be able } \\
\text { to hold a thin or deep bed } \\
\text { of sorbent at given } \\
\text { temperature and expose } \\
\text { sorbent to a generated air } \\
\text { stream containing water } \\
\text { (and any potentially co- } \\
\text { adsorbed species) at } \\
\text { varying concentrations } \\
\text { within the specified } \\
\text { concentration range and } \\
\text { gas velocity. } \\
\text { Sorbents should be } \\
\text { analyzed after testing to } \\
\text { confirm iodine loading }\end{array}$ & Equipment size & $\begin{array}{l}\text { ORNL has an extended test in progress that is } \\
\text { designed to determine the saturation } \\
\text { concentration of } \mathrm{I}_{2} \text { on } \mathrm{AgZ} \text { under VOG } \\
\text { conditions }\end{array}$ \\
\hline 2 & $\begin{array}{l}\text { Capture/removal } \\
\text { rates for primary } \\
\text { species } \\
\mathrm{mol} / \mathrm{kg} \text { sorbent } / \mathrm{h}\end{array}$ & $\begin{array}{l}\text { Adsorption rate data for selected } \\
\text { sorbent as function of iodine } \\
\text { species, temperature, and } \\
\text { concentration. } \\
\text { Recommended experimental } \\
\text { ranges and iodine species are } \\
\text { provided in Gap ID \#1. }\end{array}$ & $\begin{array}{l}\text { Extended-duration thin- } \\
\text { bed or hybrid thin-deep } \\
\text { bed testing (See Gap ID } \\
\# 1 \text { ) with the capability to } \\
\text { perform online or } \\
\text { intermittent sorbent } \\
\text { analysis. }\end{array}$ & Equipment size & \\
\hline
\end{tabular}


Table 5. Data gaps for iodine sorbent evaluations for air TPT and VOG gas streams (continued)

\begin{tabular}{|c|c|c|c|c|c|}
\hline \# & Property & Specific requirements & Approach & Data gap impact & Notes \\
\hline 3 & $\begin{array}{l}\text { Capacity for other } \\
\text { species present in } \\
\text { gas stream } \\
\mathrm{mol} / \mathrm{kg} \text { sorbent }\end{array}$ & $\begin{array}{l}\text { Maximum capacity for potential } \\
\text { co-absorbed species by selected } \\
\text { sorbent material as a function of } \\
\text { species, temperature, and } \\
\text { concentration. } \\
\text { - } \quad \text { Species of interest for } \mathrm{VOG} \\
\text { may include } \mathrm{H}_{2} \mathrm{O}, \mathrm{HNO}_{3} \text {, } \\
\mathrm{CO}_{2}, \mathrm{Cl} \text {, and } \mathrm{Br} \text {, } \\
\mathrm{H}_{2} \mathrm{O} \text { with a dew point of } 0 \\
\text { to } 40^{\circ} \mathrm{C} \text {; } \\
\mathrm{HNO}_{3} \text { concentrations from } \\
0 \text { to } 1,000 \text { ppm; } \\
\mathrm{CO} 2 \text { concentrations from } 0 \\
\text { to } 440 \text { ppm; } \\
\mathrm{Cl} \text { concentrations } \\
\text { dependent on purity of plant } \\
\text { acid } \\
\text { Br concentrations from } 0 \text { to } \\
1 \text { ppm } \\
\text { Operating temperatures } \\
\text { ranging from } 125^{\circ} \mathrm{C} \text { to } \\
175^{\circ} \mathrm{C} \text {. } \\
\text { Gas velocities ranging from } \\
5 \text { to } 100 \text { m/min. }\end{array}$ & $\begin{array}{l}\text { Extended-duration thin- } \\
\text { bed or hybrid thin-deep } \\
\text { bed testing. } \\
\text { (See Gap ID \#1) }\end{array}$ & Equipment size & $\begin{array}{l}\text { Information is available for water and } \mathrm{NO}_{\mathrm{x}} \text { from } \\
\text { thin-bed tests for a limited condition set. } \\
\text { Additional limited data are available from the } \\
\text { CETE experiment. }\end{array}$ \\
\hline 4 & $\begin{array}{l}\text { Capture/removal } \\
\text { rate for co- } \\
\text { absorbed species } \\
\mathrm{mol} / \mathrm{kg} \text { sorbent } / \mathrm{h}\end{array}$ & $\begin{array}{l}\text { Adsorption rate data for selected } \\
\text { sorbent as function of co- } \\
\text { absorbed species, their } \\
\text { concentrations, temperature, and } \\
\text { gas velocity. } \\
\text { Recommended experimental } \\
\text { ranges and potentially co- } \\
\text { adsorbing species are provided in } \\
\text { Gap ID \#3. }\end{array}$ & $\begin{array}{l}\text { Extended-duration thin- } \\
\text { bed or hybrid thin-deep } \\
\text { bed testing (See Gap ID } \\
\# 1 \text { ) with the capability to } \\
\text { perform online or } \\
\text { intermittent sorbent } \\
\text { analysis. }\end{array}$ & Equipment size & \\
\hline 5 & Change in sorbent & Iodine capacity of selected & Extended-duration thin- & Equipment size & \\
\hline
\end{tabular}


Table 5. Data gaps for iodine sorbent evaluations for air TPT and VOG gas streams (continued)

\begin{tabular}{|c|c|c|c|c|c|}
\hline$\#$ & Property & Specific requirements & Approach & Data gap impact & Notes \\
\hline & $\begin{array}{l}\text { capacity for iodine } \\
\text { in presence of other } \\
\text { species present in } \\
\text { gas stream } \\
\mathrm{mol} / \mathrm{kg} \text { sorbent }\end{array}$ & $\begin{array}{l}\text { sorbent material in the presence of } \\
\text { co-absorbed species as a function } \\
\text { of species, temperature, and } \\
\text { concentration. } \\
\text { Recommended experimental } \\
\text { ranges, iodine species, and } \\
\text { potentially co-adsorbing species } \\
\text { are provided in Gap IDs \#1 and } 3 .\end{array}$ & $\begin{array}{l}\text { bed or hybrid thin-deep } \\
\text { bed testing (See Gap ID } \\
\# 1) \text { with post-adsorption } \\
\text { sorbent analysis. }\end{array}$ & & \\
\hline 6 & $\begin{array}{l}\text { Change in iodine } \\
\text { capture rate in } \\
\text { presence of co- } \\
\text { absorbed species } \\
\mathrm{mol} / \mathrm{kg} \mathrm{sorbent} / \mathrm{h}\end{array}$ & $\begin{array}{l}\text { Iodine adsorption rate data for } \\
\text { selected sorbent as function of co- } \\
\text { absorbed species, temperature, } \\
\text { and concentration. } \\
\text { Recommended experimental } \\
\text { ranges, iodine species, and } \\
\text { potentially co-adsorbing species } \\
\text { are provided in Gap IDs \#1 and } 3 \text {. }\end{array}$ & $\begin{array}{l}\text { Extended-duration thin- } \\
\text { bed or hybrid thin-deep } \\
\text { bed testing (See Gap ID } \\
\# 1 \text { ) with the capability to } \\
\text { perform online or } \\
\text { intermittent sorbent } \\
\text { analysis. }\end{array}$ & Equipment size & \\
\hline 7 & $\begin{array}{c}\text { Selectivity } \\
\left(X_{a} / Y_{a}\right) /\left(X_{b} / Y_{b}\right) \\
\text { (unitless) } \\
\text { Where } X_{a} \text { and } X_{b} \text { are } \\
\text { mol fractions of } \\
\text { species a and } b \\
\text { respectively in the } \\
\text { adsorbed phase, and } \\
Y_{a} \text { and } Y_{b} \text { are mol } \\
\text { fractions of species } \\
\text { a and } b \text { in the bulk } \\
\text { phase }\end{array}$ & Derived from Gap ID \#3-6. & $\begin{array}{l}\text { Thin-bed testing with } \\
\text { post-adsorption sorbent } \\
\text { analysis. } \\
\text { (See Gap ID \#5) }\end{array}$ & Equipment size & $\begin{array}{l}\text { Derived from data on co-absorption studies } \\
\text { shown above. } \\
\text { Should include information on general co- } \\
\text { adsorbents (such as } \mathrm{NO}_{\mathrm{x}} \text { and water), or with } \\
\text { tramp halogens (chlorine, bromine, fluorine). }\end{array}$ \\
\hline 8 & $\begin{array}{c}\text { Sorbent particle } \\
\text { density } \\
\mathrm{kg} / \mathrm{m}^{3}\end{array}$ & $\begin{array}{l}\text { Density of individual particles in } \\
\mathrm{kg} / \mathrm{m}^{3} \text {. }\end{array}$ & $\begin{array}{l}\text { Direct measurement or } \\
\text { from manufacturer. }\end{array}$ & Equipment size & \\
\hline
\end{tabular}


Table 5. Data gaps for iodine sorbent evaluations for air TPT and VOG gas streams (continued)

\begin{tabular}{|c|c|c|c|c|c|}
\hline$\#$ & Property & Specific requirements & Approach & Data gap impact & Notes \\
\hline 9 & $\begin{array}{l}\text { Sorbent bulk } \\
\text { density } \\
\mathrm{kg} / \mathrm{m}^{3}\end{array}$ & $\begin{array}{l}\text { Bulk density of bed of sorbent } \\
\text { material in typical loading } \\
\text { configuration in } \mathrm{kg} / \mathrm{m}^{3} \text {. }\end{array}$ & $\begin{array}{l}\text { Direct measurement or } \\
\text { from manufacturer. }\end{array}$ & Equipment size & \\
\hline 10 & $\begin{array}{c}\begin{array}{c}\text { Specific heat } \\
\text { capacity }\end{array} \\
\mathrm{J} / \mathrm{K} / \mathrm{kg} \\
\end{array}$ & $\begin{array}{l}\text { Specific heat capacity of fresh and } \\
\text { loaded sorbent from } 25^{\circ} \mathrm{C}-300^{\circ} \mathrm{C} \text {. }\end{array}$ & $\begin{array}{l}\text { Direct measurement of } \\
\text { fresh sorbent and loaded } \\
\text { sorbent. }\end{array}$ & Heat duty & \\
\hline 11 & $\begin{array}{c}\text { Thermal } \\
\text { conductivity } \\
W / m / K\end{array}$ & $\begin{array}{l}\text { Thermal conductivity of fresh and } \\
\text { loaded sorbent from } 25^{\circ} \mathrm{C}-300^{\circ} \mathrm{C} \text {. }\end{array}$ & $\begin{array}{l}\text { Direct measurement of } \\
\text { fresh sorbent and loaded } \\
\text { sorbent. }\end{array}$ & Heat duty & \\
\hline 12 & $\begin{array}{l}\text { Radiation stability } \\
\text { \% degradation in } \\
\text { capacity, adsorption } \\
\text { rate, regeneration } \\
\text { time, and MTZ over } \\
\text { time as a function of } \\
\text { radiation exposure }\end{array}$ & $\begin{array}{l}\text { Capacity for iodine and iodine } \\
\text { adsorption rate as a function of } \\
\text { adsorbed dose. } \\
\text { Total dose requirement is design } \\
\text { dependent. } \\
\text { Total dose should factor in both } \\
\text { external dose and internal dose. }\end{array}$ & $\begin{array}{l}\text { Irradiation and thin-bed } \\
\text { testing. } \\
\text { Exposure of the sorbent to } \\
\text { both } \gamma \text { and } \beta \text { radiation for } \\
\text { a range of total doses. } \\
\text { Testing of the sorbent with } \\
\text { both thin- and deep-bed } \\
\text { testing to characterize } \\
\text { radiation effects. } \\
\text { (Thin-bed testing: See } \\
\text { Gap IDs \#1 and \#5) }\end{array}$ & Material life cycle & $\begin{array}{l}\text { Information likely necessary as beds are online } \\
\text { for very long periods of time ( } 1 \text { year) and may } \\
\text { be subject to external dose (design dependent). }\end{array}$ \\
\hline 13 & $\begin{array}{c}\begin{array}{c}\text { Mechanical } \\
\text { stability }\end{array} \\
N / m m \text { (load } v s \\
\text { particle diameter) } \\
\mu g / m^{3} \text { loss to gas } \\
\text { stream }\end{array}$ & $\begin{array}{l}\text { Determination of the fines } \\
\text { generation and mechanical } \\
\text { strength of the sorbent material. }\end{array}$ & $\begin{array}{l}\text { Direct measurement. } \\
\text { Measurements of both } \\
\text { particle crush strength } \\
\text { and abrasion resistance } \\
\text { will be required }\end{array}$ & Material life cycle & $\begin{array}{l}\text { Previous tests have indicated that Ag-Aerogel } \\
\text { could generate fines under VOG conditions; } \\
\text { AgZ appears to be stable over that timeframe. }\end{array}$ \\
\hline 14 & $\begin{array}{l}\text { Thermal stability } \\
\% \text { degradation in }\end{array}$ & $\begin{array}{l}\text { Determine the extent of capacity } \\
\text { loss due to extended exposure to } \\
\text { operating temperature. Determine }\end{array}$ & $\begin{array}{l}\text { Thin-bed testing. } \\
\text { (See Gap ID \#1) }\end{array}$ & Material life cycle & $\begin{array}{l}\text { Previous tests have not resulted in appreciable } \\
\text { observed thermal instability over time intervals } \\
\text { for AgZ lifetime in DOG systems. VOG/TPTOG }\end{array}$ \\
\hline
\end{tabular}


Table 5. Data gaps for iodine sorbent evaluations for air TPT and VOG gas streams (continued)

\begin{tabular}{|c|c|c|c|c|c|}
\hline$\#$ & Property & Specific requirements & Approach & Data gap impact & Notes \\
\hline & $\begin{array}{c}\text { capacity over time at } \\
\text { selected operating } \\
\text { temperature }\end{array}$ & $\begin{array}{l}\text { the extent of capacity loss due to } \\
\text { thermal excursions. }\end{array}$ & & & will be online much longer. \\
\hline 15 & $\begin{array}{l}\text { Chemical stability } \\
\text { \% degradation in } \\
\text { capacity over time } \\
\text { as a function of } \\
\text { other species present } \\
\text { in gas stream } \\
\end{array}$ & $\begin{array}{l}\text { Determine the degradation in } \\
\text { sorption performance (capacity, } \\
\text { rate, etc.) as a function of } \\
\text { contaminants in the gas feed } \\
\text { system (e.g., } \mathrm{NO}_{\mathrm{x}} \text {, tramp } \\
\text { halogens, etc.). }\end{array}$ & $\begin{array}{l}\text { Thin-bed testing. } \\
\text { (See Gap ID \#1) }\end{array}$ & Material life cycle & $\begin{array}{l}\text { Aging tests have shown impact for both } \mathrm{AgZ} \\
\text { and Ag-Aerogel. }\end{array}$ \\
\hline 16 & \begin{tabular}{|c|} 
Reactivity \\
Compatibility as \\
determined by \\
standardized \\
compatibility tables \\
\end{tabular} & $\begin{array}{l}\text { Confirmation that any } \\
\text { compatibility issues can be } \\
\text { avoided through selection of } \\
\text { materials of construction, } \\
\text { appropriate pretreatment of gas } \\
\text { stream, operational envelope, etc. }\end{array}$ & Direct evaluation. & Material life cycle & $\begin{array}{l}\text { AgZ appears to be compatible with all elements } \\
\text { of the system. }\end{array}$ \\
\hline 17 & $\begin{array}{c}\text { Regeneration } \\
\text { capacity stability } \\
\% \text { initial capacity } \\
\text { vs. cycle } \\
\end{array}$ & $\begin{array}{l}\% \text { degradation as a function of } \\
\text { regeneration temperature and } \\
\text { duration. This is not applicable } \\
\text { for Ag-based iodine adsorbents; } \\
\text { one-time use only. }\end{array}$ & $\mathrm{N} / \mathrm{A}$ & $\mathrm{N} / \mathrm{A}$ & \\
\hline 18 & $\begin{array}{l}\text { Desorption rate of } \\
\text { iodine during post } \\
\text { loading purge } \\
\mathrm{mol} / \mathrm{kg} \text { sorbent } / \mathrm{h}\end{array}$ & $\begin{array}{l}\text { Desorption of iodine as a function } \\
\text { of operating temperature and } \\
\text { purge gas velocity. } \\
\text { - } \quad \text { Operating temperatures } \\
\text { ranging from } 125^{\circ} \mathrm{C} \text { to } \\
175^{\circ} \mathrm{C} \text {. } \\
\text { - Gas velocities ranging from } \\
5 \text { to } 100 \mathrm{~m} / \mathrm{min} \text {. } \\
\end{array}$ & $\begin{array}{l}\text { Thin-bed testing. } \\
\text { (See Gap ID \#1) }\end{array}$ & $\begin{array}{l}\text { Operational } \\
\text { sequencing }\end{array}$ & $\begin{array}{l}\text { Some data are available for existing } \mathrm{AgZ} \text { and } \\
\text { Ag-Aerogel sorbent from thin-bed and deep-bed } \\
\text { testing. }\end{array}$ \\
\hline 19 & $\begin{array}{l}\text { Desorption of co- } \\
\text { adsorbed species } \\
\text { mol co-adsorbed } \\
\text { species retained/kg } \\
\text { sorbent } \\
\end{array}$ & $\begin{array}{l}\% \text { of co-adsorbed species } \\
\text { desorbed during selected } \\
\text { regeneration conditions. } \\
\text { Recommended experimental } \\
\text { ranges and potentially co- }\end{array}$ & $\begin{array}{l}\text { Thin- and deep-bed } \\
\text { testing. } \\
\text { (See Gap ID \#1) }\end{array}$ & $\begin{array}{l}\text { Equipment } \\
\text { size/material life } \\
\text { cycle }\end{array}$ & \\
\hline
\end{tabular}


Table 5. Data gaps for iodine sorbent evaluations for air TPT and VOG gas streams (continued)

\begin{tabular}{|c|c|c|c|c|c|}
\hline \# & Property & Specific requirements & Approach & Data gap impact & Notes \\
\hline & & $\begin{array}{l}\text { adsorbing species are provided in } \\
\text { Gap ID } \# 3 \text {. }\end{array}$ & & & \\
\hline 20 & $\begin{array}{c}\begin{array}{c}\text { Desorption rate of } \\
\text { co-adsorbed species }\end{array} \\
\mathrm{mol} / \mathrm{kg} \text { sorbent } / \mathrm{h}\end{array}$ & $\begin{array}{l}\text { Desorption rate as a function of } \\
\text { desorption temperature and purge } \\
\text { stream gas velocity. } \\
\text { Recommended experimental } \\
\text { ranges and potentially co- } \\
\text { adsorbing species are provided in } \\
\text { Gap ID \#3. }\end{array}$ & $\begin{array}{l}\text { Thin- and deep-bed } \\
\text { testing. } \\
\text { (See Gap ID \#1) }\end{array}$ & Material life cycle & \\
\hline 21 & $\begin{array}{l}\text { Purity of desorbed } \\
\text { iodine streams } \\
\text { ppm or } \% \text { iodine }\end{array}$ & $\begin{array}{l}\text { Prescribed by waste treatment } \\
\text { operation. }\end{array}$ & $\begin{array}{l}\text { Purge of deep beds used } \\
\text { in previous tests with gas } \\
\text { analysis. }\end{array}$ & $\begin{array}{l}\text { Equipment size } \\
\text { and waste } \\
\text { treatment process } \\
\text { design } \\
\end{array}$ & Sizing of downstream processes. \\
\hline 22 & $\begin{array}{c}\text { Cooling time } \\
h\end{array}$ & $\begin{array}{l}\text { Hours to cool from pretreatment } \\
\text { temperature }\left(270^{\circ} \mathrm{C}\right) \text { to adsorbing } \\
\text { temperature }\left(150^{\circ} \mathrm{C}\right) \text { and to } \\
\text { ambient temperature after purge. }\end{array}$ & $\begin{array}{l}\text { Derived from heat } \\
\text { capacity, thermal } \\
\text { conductivity, and bed } \\
\text { design. }\end{array}$ & $\mathrm{N} / \mathrm{A}$ & \\
\hline \multicolumn{6}{|c|}{ Metrics for system design and performance criterion } \\
\hline 23 & $\begin{array}{c}\text { Pressure drop } \\
\mathrm{Pa} / \mathrm{m} \text { vs } \mathrm{m}^{2} \text { column }\end{array}$ & $\begin{array}{l}\text { Size columns and sorbent size for } \\
<2.5 \mathrm{kPa} \text { pressure drop based on } \\
\text { expected gas flow rates. }\end{array}$ & $\begin{array}{l}\text { Direct measurement or } \\
\text { scaled derivation. }\end{array}$ & $\begin{array}{l}\text { Operational } \\
\text { sequencing/equip } \\
\text { ment size }\end{array}$ & \\
\hline 24 & $\begin{array}{c}\begin{array}{c}\text { Decontamination } \\
\text { factor (DF) }\end{array} \\
{[I]_{\text {inlet }}[I]_{\text {outlet }}} \\
\text { (unitless) }\end{array}$ & $\begin{array}{l}\text { DF data as function of sorbent, } \\
\text { iodine species, their } \\
\text { concentrations, temperature, and } \\
\text { bed depth. } \\
\text { Recommended experimental } \\
\text { ranges and iodine species are } \\
\text { provided in Gap ID \#1. }\end{array}$ & $\begin{array}{l}\text { Deep-bed testing with } \\
\text { online measurement of } \\
\text { inlet and effluent iodine } \\
\text { concentrations. } \\
\text { Test system must be able } \\
\text { to hold a deep bed of } \\
\text { sorbent at given } \\
\text { temperature and expose } \\
\text { sorbent to a generated air } \\
\text { stream containing water } \\
\text { (and any potentially co- } \\
\text { adsorbed species) at }\end{array}$ & Equipment size & $\begin{array}{l}\text { DFs exist for } \mathrm{I}_{2} \text { and methyl iodide adsorption on } \\
\text { AgZ and Ag-Aerogel for selected, limited test } \\
\text { conditions. }\end{array}$ \\
\hline
\end{tabular}


Data Requirements and Test System Needs for Development of an Integrated Off-Gas Treatment System

Table 5. Data gaps for iodine sorbent evaluations for air TPT and VOG gas streams (continued)

\begin{tabular}{|c|c|l|l|l|l|}
\hline$\#$ & Property & \multicolumn{1}{|c|}{ Specific requirements } & \multicolumn{1}{|c|}{ Approach } & Data gap impact & \\
\hline & & $\begin{array}{l}\text { varying concentrations } \\
\text { within the specified } \\
\text { concentration range and } \\
\text { gas velocity. Both inlet } \\
\text { and effluent gas streams } \\
\text { must be assessed for } \\
\text { iodine concentration. }\end{array}$ & & Notes \\
\hline $\mathbf{2 5}$ & $\begin{array}{c}\text { Length of Mass } \\
\text { Transfer Zone } \\
\text { (MTZ) }\end{array}$ & $\begin{array}{l}\text { Length of MTZ as a function of } \\
\text { gas velocity, target species } \\
\text { concentration, temperature, and } \\
\text { presence of co-absorbed species } \\
\text { shown to have impact on total } \\
\text { capacity or adsorption rate }>10 \% .\end{array}$ & $\begin{array}{l}\text { Deep-bed tests with bed } \\
\text { depth that captures } 1.5 \\
\text { times MTZ. Predictions } \\
\text { can be made from thin- } \\
\text { bed tests and data may } \\
\text { also be determined from } \\
\text { DF testing using deep } \\
\text { beds. } \\
\text { Recommended experimental } \\
\text { ranges and iodine species are } \\
\text { provided in Gap ID \#1. }\end{array}$ & $\begin{array}{l}\text { Equipment size } \\
\text { (Deep-bed testing: Gap } \\
\text { ID \#24). }\end{array}$ & $\begin{array}{l}\text { Estimates of length of MTZ exist for } \mathrm{I}_{2} \text { and } \\
\text { methyl iodide adsorption on AgZ and Ag- } \\
\text { Aerogel for selected, limited test conditions. }\end{array}$ \\
\hline
\end{tabular}




\section{$4.4 \quad \mathrm{NO}_{\mathrm{x}}$ recovery systems}

As shown in Figures 1 and 3, the $\mathrm{NO}_{\mathrm{x}}$ recovery system is downstream of the iodine trapping system. At this point the off-gas streams have been decontaminated of $\mathrm{Ru},{ }^{3} \mathrm{H}$, and iodine to meet requirements, so only trace amounts of these species remain. The primary species arising from fuel dissolution and TPT (when TPT is used) and entering the $\mathrm{NO}_{\mathrm{x}}$ system are $\mathrm{NO}_{\mathrm{x}}$ (consisting of $\mathrm{N}_{2} \mathrm{O}, \mathrm{NO}$, and $\mathrm{NO}_{2}$ ), $\mathrm{CO}, \mathrm{CO}_{2}$, $\mathrm{Xe}, \mathrm{Kr}$, and the carrier gas (e.g., components of air including $\mathrm{N}_{2}, \mathrm{O}_{2}, \mathrm{CO}_{2}, \mathrm{Ar}, \mathrm{H}_{2} \mathrm{O}$, etc.). Vapors of nitric and nitrous acids will also be present in low concentrations. Traces of organic species arising from dissolution may be present. These organics arise from the recycle acid stream where small amounts of organics from solvent extraction operations dissolve or are entrained in the aqueous phase. Some of these organics may have become iodated during dissolution, and stripping of the iodine from the organic molecule in the AgZ treatment step could produce alcohols, ethers, or other organic species.

$\mathrm{NO}_{\mathrm{x}}$ recovery systems often scrub the gas phase with water or nitric acid to recover the nitrogen oxides as nitric acid. The acid is recycled and reused within the plant. In the late 1970s and early 1980s, there was a significant effort to better understand the chemical processes (Counce and Groenier 1978) and to develop methods to design sieve-plate (Counce 1978; Counce and Perona 1979a, 1979b and 1980), bubble cap (Counce 1979), and packed (Counce 1980) scrubbing towers in nuclear fuel reprocessing plants. The presence of oxygen is necessary to improve the scrubbing efficiency of $\mathrm{NO}$ and $\mathrm{N}_{2} \mathrm{O}$, converting them in situ to $\mathrm{NO}_{2}$. Fractional recovery of $\mathrm{NO}_{\mathrm{x}}$ is variable with tower height (number of theoretical equilibrium stages), is limited to equilibrium vapor pressures above the fed scrubbing solution, and is usually set by optimization of the capital and operating costs. Removal of residual trace amounts of $\mathrm{NO}_{\mathrm{x}}$ can be implemented using zeolite-based MS, but this would seem unnecessary because trace amounts are expected to be captured in the $\mathrm{CO}_{2}$ recovery system (Section 4.5).

The $\mathrm{CO}, \mathrm{CO}_{2}$, inert components of the carrier gas, and the noble gases are sparingly soluble in the acidic aqueous scrubbing solution and will pass to the next step in the off-gas treatment train. Organic compounds will be the more troublesome components entering the $\mathrm{NO}_{\mathrm{x}}$ recovery system. How these organics behave is mostly unknown, and there is a need for study to ascertain if such compounds will cause safety or operational problems. For example, a portion of these organics may be converted to organic nitrates or acids that could collect in the aqueous systems. Accumulation of oil-like nitrates is a potential safety issue. Many organic acids are volatile and may be transported to the $\mathrm{CO}_{2}$ recovery system. Residual trace iodine entering the system may be converted to an iodate, precipitate, and accumulate in the equipment.

Although $\mathrm{NO}_{\mathrm{x}}$ scrubbers are considered relatively standard industrial equipment, there appears to be limited experience in the design and sizing of this equipment within the reprocessing community, and there is a declining experience base of staff with experience in scrubber operation. A small pilot facility to support the collection of additional design data and to train staff is needed. Key data that should be of the highest priority is the absorption capacities for both the species of interest and the residual iodine and tritium that may breakthrough the primary abatement systems (Table 6, Gap ID \#1-7). It is envisioned that the recovered acid would be recycled within the plant, so the long-term accumulation and potential recycle rates are of interest. Iodine captured in the $\mathrm{NO}_{\mathrm{x}}$ scrubber and recycled back to the dissolver would have an additional opportunity to be captured in the DOG iodine sorbent beds, but if recycled back to the acid recovery system, the iodine could be spread to elsewhere within the facility. Little ${ }^{14} \mathrm{CO}_{2}$ coabsorption is expected but should be confirmed. 
Table 6. Data gaps for $\mathrm{NO}_{\mathrm{x}}$ absorber evaluations

\begin{tabular}{|c|c|c|c|c|c|}
\hline \# & $\begin{array}{c}\text { Property } \\
\text { Units }\end{array}$ & Specific requirements & Approach & Data gap impact & Notes \\
\hline \multicolumn{6}{|c|}{ Metrics for technical performance and physical and chemical characteristics criterion } \\
\hline 1 & $\begin{array}{l}\text { Absorption Capacity } \\
\text { mol } / \mathrm{m}^{3} \text { absorbent } \\
\text { liquid }\end{array}$ & 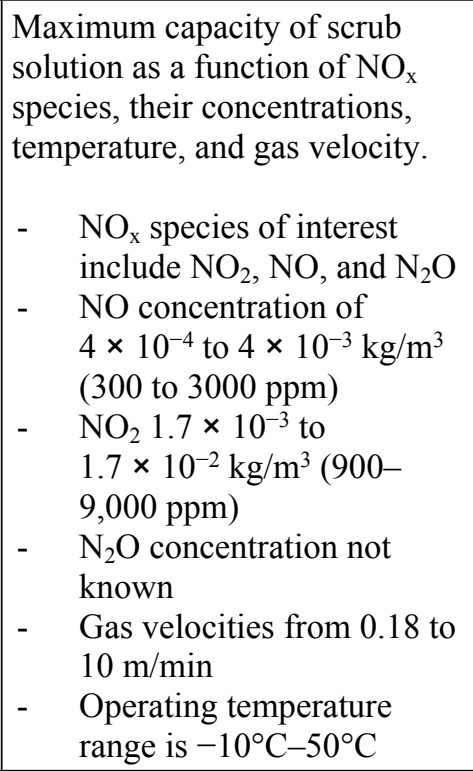 & $\begin{array}{l}\text { Chemical equilibrium } \\
\text { modeling and detailed } \\
\text { scrubber design; } \\
\text { demonstrated in pilot- } \\
\text { scale tests. }\end{array}$ & $\begin{array}{l}\text { Equipment size, } \\
\text { discharge nitric } \\
\text { acid stream flow } \\
\text { rate and } \\
\text { composition. }\end{array}$ & $\begin{array}{l}\text { Design methodologies have been reported and } \\
\text { should be re-evaluated. }\end{array}$ \\
\hline 2 & $\begin{array}{l}\text { Capture removal } \\
\text { rates for primary } \\
\text { species } \\
\text { mol/m } m^{3} \text { absorbent } \\
\quad \text { liquid } / \mathrm{h}\end{array}$ & $\begin{array}{l}\text { Adsorption rate of scrub } \\
\text { solution as a function of } \mathrm{NO}_{\mathrm{x}} \\
\text { species, their concentrations, } \\
\text { temperature, and gas velocity. } \\
\text { Recommended experimental } \\
\text { ranges and } \mathrm{NO}_{\mathrm{x}} \text { species are } \\
\text { provided in Gap ID \#1. }\end{array}$ & $\begin{array}{l}\text { Chemical modeling and in } \\
\text { situ measurement of } \\
\mathrm{HNO}_{2} \text { concentrations, and } \\
\text { changes in concentrations } \\
\text { as function of reagents } \\
\text { (e.g., } \mathrm{O}_{2} \text { sparge, } \mathrm{H}_{2} \mathrm{O}_{2} \text { ) } \\
\text { and operating conditions. }\end{array}$ & $\begin{array}{l}\text { Equipment size, } \\
\text { design, and } \\
\text { operating } \\
\text { conditions. } \\
\text { Design and } \\
\text { operation of the } \\
\text { downstream } \mathrm{CO}_{2} \\
\text { scrubber. }\end{array}$ & $\begin{array}{l}\mathrm{NO} \text { and } \mathrm{N}_{2} \mathrm{O} \text { scrubbing can be slower; causing } \\
\text { current designs to be only } 55 \% \text { to } 95 \% \text { efficient } \\
\text { for total } \mathrm{NO}_{\mathrm{x}} \text { scrubbing. } \\
\text { Need to determine effect of } \mathrm{HNO}_{2} \text { concentration } \\
\text { and methods to reduce its effect or convert it to } \\
\mathrm{HNO}_{3} \text {. }\end{array}$ \\
\hline
\end{tabular}


Table 6. Data gaps for $\mathrm{NO}_{\mathrm{x}}$ absorber evaluations (continued)

\begin{tabular}{|c|c|c|c|c|c|}
\hline \# & $\begin{array}{c}\text { Property } \\
\text { Units } \\
\end{array}$ & Specific requirements & Approach & Data gap impact & Notes \\
\hline 3 & $\begin{array}{c}\text { Capacity for other } \\
\text { species present in gas } \\
\text { stream } \\
\mathrm{mol} / \mathrm{m}^{3} \text { absorbent } \\
\text { liquid }\end{array}$ & $\begin{array}{l}\text { Maximum capacity for potential } \\
\text { co-absorbed species as a } \\
\text { function of species, their } \\
\text { concentrations, temperature, and } \\
\text { gas velocity. Co-adsorbing } \\
\text { species may include } \mathrm{CO}_{2}, \mathrm{CO} \text {, } \\
\mathrm{I}_{2} \text {, and organic acids. } \\
\text { - } \quad \text { Gas velocities of } 0.18 \text { to } 10 \\
\text { m/min } \\
\text { Operating temperature } \\
\text { range is }-10^{\circ} \mathrm{C} \text { to } 50^{\circ} \mathrm{C} \\
\text { - } \quad \mathrm{CO}_{2} 7.7 \times 10^{-4} \mathrm{~kg} / \mathrm{m}^{3}(400 \\
\text { ppm) } \\
\mathrm{CO} \text { not } \mathrm{known} \text { but not } \\
\text { expected to be important. } \\
\text { - } \mathrm{I}_{2} 8.7 \times 10^{-8} \mathrm{~kg} / \mathrm{m}^{3}(0.01 \\
\text { ppm) } \\
\text { Organic specie } \\
\text { concentrations not known }\end{array}$ & $\begin{array}{l}\text { Column scrubber tests } \\
\text { and/or column } \\
\text { engineering models. Tests } \\
\text { with steam stripping, } \\
\mathrm{H}_{2} \mathrm{O}_{2} \text { addition or other } \\
\text { techniques. Identification } \\
\text { of organics entering } \\
\text { system and conversion to } \\
\text { organic nitrates and/or } \\
\text { acids. }\end{array}$ & $\begin{array}{l}\text { Equipment } \\
\text { size/operational } \\
\text { sequencing. } \\
\text { Safety issues and } \\
\text { degradation of } \\
\text { scrubbing } \\
\text { efficiency. }\end{array}$ & $\begin{array}{l}\text { Of particular interest: Iodine retention and/or } \\
\text { accumulation; escape of less easily scrubbed } \\
\text { NO; and disposition of organic compounds, } \\
\text { solubility limits. }\end{array}$ \\
\hline 4 & $\begin{array}{c}\begin{array}{c}\text { Capture/removal rate } \\
\text { for co-absorbed } \\
\text { species }\end{array} \\
\text { Mol } / \mathrm{m}^{3} \text { absorbent } \\
\text { liquid } / \mathrm{h}\end{array}$ & $\begin{array}{l}\text { Adsorption rate data for selected } \\
\text { sorbent as function of co- } \\
\text { absorbed species, temperature, } \\
\text { and concentration } \\
\text { Recommended experimental } \\
\text { ranges and potentially co- } \\
\text { adsorbing species are provided } \\
\text { in Gap ID \#3. }\end{array}$ & $\begin{array}{l}\text { Calculation from chemical } \\
\text { data bases, laboratory } \\
\text { studies. }\end{array}$ & $\begin{array}{l}\text { Equipment } \\
\text { size/operational } \\
\text { sequencing. }\end{array}$ & $\begin{array}{l}\text { Concentrations of other gas species in the DOG } \\
\text { may be low enough to limit impact of co- } \\
\text { absorbed species on } \mathrm{NO}_{\mathrm{x}} \text { scrubbing. }\end{array}$ \\
\hline
\end{tabular}


Table 6. Data gaps for $\mathrm{NO}_{\mathrm{x}}$ absorber evaluations (continued)

\begin{tabular}{|c|c|c|c|c|c|}
\hline \# & $\begin{array}{c}\text { Property } \\
\text { Units }\end{array}$ & Specific requirements & Approach & Data gap impact & Notes \\
\hline 5 & $\begin{array}{c}\text { Change in sorbent } \\
\text { capacity for } \mathrm{NO}_{\mathbf{x}} \text { in } \\
\text { presence of other } \\
\text { species present in gas } \\
\text { stream } \\
\mathrm{mol} / \mathrm{m}^{3} \text { absorbent } \\
\text { liquid }\end{array}$ & $\begin{array}{l}\mathrm{NO}_{\mathrm{x}} \text { capacity accounting for } \\
\text { potential adverse effects from } \\
\text { co-absorbed species as a } \\
\text { function of species, temperature, } \\
\text { and concentration. } \\
\text { Recommended experimental } \\
\text { ranges, } \mathrm{NO}_{\mathrm{x}} \text { species, and } \\
\text { potentially coasorbing species } \\
\text { are provided in Gap IDs \#1 and } \\
\# 3 \text {. }\end{array}$ & $\begin{array}{l}\text { Calculation from chemical } \\
\text { data bases, laboratory } \\
\text { studies. }\end{array}$ & Equipment size & $\begin{array}{l}\text { Concentrations of other gas species in the DOG } \\
\text { may be low enough to limit impact of co- } \\
\text { absorbed species on } \mathrm{NO}_{\mathrm{x}} \text { scrubbing. }\end{array}$ \\
\hline 6 & $\begin{array}{l}\text { Change in } \mathbf{N O}_{\mathbf{x}} \\
\text { capture rate in } \\
\text { presence of co- } \\
\text { absorbed species } \\
\mathrm{mol} / \mathrm{m}^{3} \text { absorbent } \\
\text { liquid } / \mathrm{h}\end{array}$ & $\begin{array}{l}\mathrm{NO}_{\mathrm{x}} \text { adsorption rate data for } \\
\text { selected sorbent as function of } \\
\text { co-absorbed species, } \\
\text { temperature, and concentration. } \\
\text { Recommended experimental } \\
\text { ranges, } \mathrm{NO}_{\mathrm{x}} \text { species, and } \\
\text { potentially coasorbing species } \\
\text { are provided in Gap IDs \#1 and } \\
\# 3 \text {. }\end{array}$ & $\begin{array}{l}\text { Calculation from chemical } \\
\text { data bases, laboratory } \\
\text { studies. }\end{array}$ & Equipment size & $\begin{array}{l}\text { Concentrations of other gas species in the DOG } \\
\text { may be low enough to limit impact of co- } \\
\text { absorbed species on } \mathrm{NO}_{\mathrm{x}} \text { scrubbing. }\end{array}$ \\
\hline 7 & $\begin{array}{c}\text { Selectivity } \\
\left(X_{a} / Y_{a}\right) /\left(X_{b} / Y_{b}\right) \\
\text { (unitless) } \\
\text { Where } X_{a} \text { and } X_{b} \text { are } \\
\text { mol fractions of } \\
\text { species a and } b \\
\text { respectively in the } \\
\text { adsorbed phase, and } \\
Y_{a} \text { and } Y_{b} \text { are mol } \\
\text { fractions of species a } \\
\text { and } b \text { in the bulk phase }\end{array}$ & $\begin{array}{l}\text { Determination of amounts of } \\
\mathrm{NO}_{\mathrm{x}} \text { and contaminants that } \\
\text { adsorb (derived from Gap IDs } \\
\# 3-6) \text {. }\end{array}$ & $\begin{array}{l}\text { Determination from } \\
\text { chemical and engineering } \\
\text { literature; laboratory and } \\
\text { pilot tests. }\end{array}$ & $\begin{array}{l}\text { Equipment } \\
\text { size/operational } \\
\text { sequencing./proce } \\
\text { ss safety. }\end{array}$ & $\begin{array}{l}\text { Detailed models have been developed for } \mathrm{NO}_{\mathrm{x}} \\
\text { scrubbing. Lab tests or pilot tests are needed to } \\
\text { confirm chemical and engineering literature. }\end{array}$ \\
\hline
\end{tabular}


Data Requirements and Test System Needs for Development of an Integrated Off-Gas Treatment

Table 6. Data gaps for $\mathrm{NO}_{\mathrm{x}}$ absorber evaluations (continued)

\begin{tabular}{|c|c|c|c|c|c|}
\hline \# & $\begin{array}{l}\text { Property } \\
\text { Units }\end{array}$ & Specific requirements & Approach & Data gap impact & Notes \\
\hline 8 & $\begin{array}{c}\text { Sorbent density } \\
\mathrm{kg} / \mathrm{m}^{3} \text { absorbent liquid }\end{array}$ & Density of aqueous solution. & $\begin{array}{l}\text { Direct measurement or } \\
\text { from manufacturer. }\end{array}$ & Equipment size & $\begin{array}{l}\text { Methods exist to estimate aqueous solution } \\
\text { density to high precision. }\end{array}$ \\
\hline 9 & $\begin{array}{l}\text { Sorbent bulk density } \\
\mathrm{kg} / \mathrm{m}^{3} \text { absorbent liquid }\end{array}$ & $\begin{array}{l}\text { N/A, liquid is a continuous } \\
\text { phase. }\end{array}$ & N/A & N/A & \\
\hline 10 & $\begin{array}{l}\text { Specific heat capacity } \\
\qquad J / K / k g\end{array}$ & $\begin{array}{l}\text { Specific heat capacity of fresh } \\
\text { and loaded absorbent from } \\
-15^{\circ} \mathrm{C}-50^{\circ} \mathrm{C} \text {. }\end{array}$ & $\begin{array}{l}\text { Direct measurement of } \\
\text { fresh sorbent and loaded } \\
\text { sorbent. }\end{array}$ & Heat duty & Estimated from properties of water and acid. \\
\hline 11 & $\begin{array}{l}\text { Thermal conductivity } \\
\qquad \mathrm{W} / \mathrm{m} / \mathrm{K}\end{array}$ & $\begin{array}{l}\text { Thermal conductivity of } \\
\text { absorbent from }-15^{\circ} \mathrm{C}-50^{\circ} \mathrm{C} \text {. }\end{array}$ & $\begin{array}{l}\text { Direct measurement of } \\
\text { fresh sorbent and loaded } \\
\text { sorbent. }\end{array}$ & $\begin{array}{l}\text { Heat } \\
\text { duty/operational } \\
\text { sequencing }\end{array}$ & Estimated from properties of water and acid. \\
\hline 12 & $\begin{array}{l}\text { Radiation stability } \\
\text { \% degradation in } \\
\text { capacity and/or } \\
\text { absorption rate over } \\
\text { time as a function of } \\
\text { radiation exposure }\end{array}$ & $\begin{array}{l}\text { Change in scrubber DF and } \\
\text { absorber capacity as a function } \\
\text { of absorbed dose. }\end{array}$ & $\begin{array}{l}\text { Gamma irradiation of } \\
\text { selected scrubber solution } \\
\text { compositions; } \\
\text { measurement of amounts } \\
\text { of irradiated species and } \\
\text { reaction products. }\end{array}$ & $\begin{array}{l}\text { Radiolysis } \\
\text { producing simpler } \\
\text { reactive } \\
\text { molecules or } \\
\text { causing } \\
\text { polymerization of } \\
\text { co-adsorbed } \\
\text { species }\end{array}$ & $\begin{array}{l}\text { Effect on neat scrubbing solution is of little } \\
\text { concern, but how complex or reactive species } \\
\text { form is unknown. }\end{array}$ \\
\hline 13 & $\begin{array}{c}\text { Mechanical stability } \\
\mathrm{N} / \mathrm{mm} \text { (load vs particle } \\
\text { diameter) } \\
\mu \mathrm{g} / \mathrm{m}^{3} \text { loss to gas } \\
\text { stream }\end{array}$ & N/A & N/A & $\mathrm{N} / \mathrm{A}$ & \\
\hline 14 & $\begin{array}{l}\text { Thermal stability } \\
\text { \% degradation in } \\
\text { capacity over time at } \\
\text { selected operating } \\
\text { temperature }\end{array}$ & N/A & N/A & N/A & \\
\hline
\end{tabular}


Data Requirements and Test System Needs for Development of an Integrated Off-Gas Treatment System

Table 6. Data gaps for $\mathrm{NO}_{\mathrm{x}}$ absorber evaluations (continued)

\begin{tabular}{|c|c|c|c|c|c|}
\hline \# & $\begin{array}{c}\text { Property } \\
\text { Units }\end{array}$ & Specific requirements & Approach & Data gap impact & Notes \\
\hline 15 & $\begin{array}{l}\text { Chemical stability } \\
\text { \% degradation in } \\
\text { capacity over time as a } \\
\text { function of other } \\
\text { species present in gas } \\
\text { stream }\end{array}$ & N/A & N/A & N/A & \\
\hline 16 & $\begin{array}{c}\text { Reactivity } \\
\text { Compatibility as } \\
\text { determined by } \\
\text { standardized } \\
\text { compatibility tables }\end{array}$ & $\begin{array}{l}\text { Confirmation that any } \\
\text { compatibility issues can be } \\
\text { avoided through selection of } \\
\text { materials of construction, } \\
\text { appropriate pretreatment of gas } \\
\text { stream, operational envelope, } \\
\text { etc. }\end{array}$ & Direct evaluation & Material life cycle & \\
\hline 17 & $\begin{array}{c}\text { Regeneration } \\
\text { No. of cycles before } \\
\text { degrading to } 80 \% \text { of } \\
\text { capacity for the target } \\
\text { element }\end{array}$ & $\mathrm{N} / \mathrm{A}$ & N/A & N/A & $\begin{array}{l}\text { Acid solution is recycled, main concern is } \\
\text { accumulation of organics in the recycled acid. }\end{array}$ \\
\hline 18 & $\begin{array}{c}\text { Desorption rate of } \\
\text { NO during post } \\
\text { loading purge } \\
\mathrm{mol} / \mathrm{m}^{3} \text { absorbent } \\
\text { liquid } / \mathrm{h}\end{array}$ & N/A & N/A & N/A & This metric/gap not considered for scrubbers. \\
\hline 19 & $\begin{array}{l}\text { Desorption of co- } \\
\text { adsorbed species } \\
\text { mol co-adsorbed } \\
\text { species retained/m } \\
\text { sorbent }\end{array}$ & N/A & N/A & N/A & This metric/gap not considered for scrubbers. \\
\hline
\end{tabular}


Data Requirements and Test System Needs for Development of an Integrated Off-Gas Treatment

Table 6. Data gaps for $\mathrm{NO}_{\mathrm{x}}$ absorber evaluations (continued)

\begin{tabular}{|c|c|c|c|c|c|}
\hline \# & $\begin{array}{c}\text { Property } \\
\text { Units }\end{array}$ & Specific requirements & Approach & Data gap impact & Notes \\
\hline 20 & $\begin{array}{l}\text { Desorption rate of co- } \\
\text { adsorbed species } \\
\text { mol } / \mathrm{m}^{3} \text { absorbent } \\
\text { liquid/h }\end{array}$ & N/A & N/A & N/A & This metric/gap not considered for scrubbers. \\
\hline 21 & $\begin{array}{c}\text { Purity of desorbed } \\
\text { NOx streams } \\
\text { ppm or } \% N O_{x} \\
\end{array}$ & $\mathrm{~N} / \mathrm{A}$ & N/A & N/A & This metric/gap not considered for scrubbers. \\
\hline 22 & $\begin{array}{c}\text { Cooling time } \\
h\end{array}$ & $\mathrm{~N} / \mathrm{A}$ & N/A & N/A & This metric/gap not considered for scrubbers. \\
\hline \multicolumn{6}{|c|}{ Metrics for system design and performance criterion } \\
\hline 23 & $\begin{array}{c}\text { Pressure drop } \\
\mathrm{Pa} / \mathrm{m} \text { vs } \mathrm{m}^{2} \text { column }\end{array}$ & $\begin{array}{l}\text { Column size required for } \\
<2.5 \mathrm{kPa} \text { pressure drop based on } \\
\text { expected gas flow rates. }\end{array}$ & $\begin{array}{l}\text { Direct measurement or } \\
\text { scaled derivation. }\end{array}$ & $\begin{array}{l}\text { Operational } \\
\text { sequencing/equip } \\
\text { ment size } \\
\end{array}$ & \\
\hline 24 & $\begin{array}{c}\text { Decontamination } \\
\text { factor }(\mathbf{D F}) \\
{\left[N O_{x}\right]_{\text {inlet }} /\left[N O_{x}\right]_{\text {outlet }}} \\
\text { (unitless) }\end{array}$ & $\begin{array}{l}\text { DF data as function of sorbent, } \\
\text { iodine species, operating temp, } \\
\text { concentration, time, and bed } \\
\text { depth. }\end{array}$ & $\begin{array}{l}\text { Calculation/engineering } \\
\text { design }\end{array}$ & $\begin{array}{l}\text { Equipment } \\
\text { size/operational } \\
\text { sequencing }\end{array}$ & $\begin{array}{l}\text { Overall DF depends on equivalent number of } \\
\text { theoretical stages and solubility equilibria. } \\
\text { Equilibria may be shifted for favorable } \\
\text { absorption in presence of oxygen. }\end{array}$ \\
\hline 25 & $\begin{array}{c}\text { Height of a } \\
\text { theoretical stage } \\
m\end{array}$ & $\begin{array}{l}\text { Height of a theoretical stage as a } \\
\text { function of gas velocity, target } \\
\text { species concentration, operating } \\
\text { temperature, and presence of co- } \\
\text { absorbed species shown to have } \\
\text { impact on total capacity or } \\
\text { absorption rate }>10 \% .\end{array}$ & $\begin{array}{l}\text { Calculation/engineering } \\
\text { design }\end{array}$ & Equipment size & \\
\hline
\end{tabular}


Data Requirements and Test System Needs for Development of an Integrated Off-Gas Treatment System

Table 6. Data gaps for $\mathrm{NO}_{\mathrm{x}}$ absorber evaluations (continued)

\begin{tabular}{|c|c|l|l|l|l|}
\hline$\#$ & $\begin{array}{c}\text { Property } \\
\text { Units }\end{array}$ & \multicolumn{1}{|c|}{ Specific requirements } & Approach & Data gap impact & \multicolumn{1}{|c|}{ Notes } \\
\hline $\mathbf{2 6}$ & $\begin{array}{l}\text { Liquid } \\
\text { volume/holdup }\end{array}$ & $\begin{array}{l}\text { Determination of required } \\
\text { system liquid inventory (holdup) } \\
\text { necessary to ensure acceptable } \\
\text { removal characteristics. Based } \\
\text { on calculated diameter and } \\
\text { height of tower. }\end{array}$ & $\begin{array}{l}\text { Engineering } \\
\text { design/operability choice }\end{array}$ & Equipment size & $\begin{array}{l}\text { Footprint and height of scrubber to be } \\
\text { calculated. }\end{array}$ \\
$m^{3}$ & & & \\
\hline
\end{tabular}




\section{$4.5 \quad \mathrm{CO}_{2}$ recovery systems}

The $\mathrm{CO}_{2}$ recovery system follows the $\mathrm{NO}_{\mathrm{x}}$ recovery system as shown in Figs. 1 and 3. The primary gases entering $\mathrm{CO}_{2}$ recovery include $\mathrm{CO}, \mathrm{CO}_{2}$, the carrier gas (usually components from air), and the noble gases. Minor components of the gas will include trace iodine, organic compounds, residual $\mathrm{NO}_{\mathrm{x}}$ gases, and acid $\left(\mathrm{HNO}_{3}\right)$ vapors. Scrubbing of the gas stream with aqueous caustic $(\mathrm{NaOH})$ solution recovers the $\mathrm{CO}_{2}$ by a combination of sorption and chemical conversion to sodium carbonate, sodium bicarbonate, or both (Meleshyn and Noseck 2012). Depending on the fraction of carbon that is present as CO, rather than $\mathrm{CO}_{2}$, the carbon capture performance will be degraded. The noble gases and inert components of the carrier gas are sparingly soluble in the caustic solution. Any iodine remaining in the gas stream will have the tendency to absorb into the caustic solution, but the rate will be limited by its very low concentration. Organic compounds will also be partially, or wholly, absorbed into the caustic solution, and the organic acids will be neutralized to the sodium salts of the acid. Nitric and nitrous acid vapors will be adsorbed and converted to sodium nitrate and sodium nitrite, respectively. Residual $\mathrm{NO}_{\mathrm{x}}$ will also be converted to nitrates and nitrites, but $\mathrm{N}_{2} \mathrm{O}$ is less reactive so a smaller fraction of it will be absorbed in the system. In the $\mathrm{CO}_{2}$ recovery system, the carbonate-laden caustic solution is treated with calcium hydroxide $\left[\mathrm{Ca}(\mathrm{OH})_{2}\right]$ to precipitate calcium carbonate $\left(\mathrm{CaCO}_{3}\right)$, which can be dewatered and prepared for disposal. The disposition of the minor compounds containing iodine and organics needs to be determined. Accumulation of an organic phase may require a skimmer or other means (e.g., part of any $\mathrm{O}_{2}$ removal system) to reduce organic vapors from entering the downstream Xe and $\mathrm{Kr}$ recovery system. Accumulation of organics may become a safety concern over periods of extended operation.

Like $\mathrm{NO}_{\mathrm{x}}$ scrubbers, $\mathrm{CO}_{2}$ scrubbers are considered relatively standard industrial equipment; however, there appears to be limited experience in the design and sizing of this equipment within the reprocessing community. Further, the experience base of staff with operating experience with remotely operated scrubbers is declining. As noted in Section 4.4, a small pilot facility to support the collection of additional design data and to train staff is needed. Key data that should be of the highest priority is the absorption capacities and impacts on waste form for both the species of interest and the residual iodine, tritium, and $\mathrm{NO}_{\mathrm{x}}$ that may breakthrough the primary abatement systems (Table 6 Gap ID \#1-7). Also of interest is the integration of a $\mathrm{NO}_{\mathrm{x}}$ and $\mathrm{CO}_{2}$ scrubber to determine the impacts of residual $\mathrm{NO}_{\mathrm{x}}$ on the $\mathrm{CO}_{2}$ scrubber performance and the subsequent waste form. 
Data Requirements and Test System Needs for Development of an Integrated Off-Gas Treatment System

Table 7. Data gaps for $\mathrm{CO}_{2}$ absorber evaluations

\begin{tabular}{|c|c|c|c|c|c|}
\hline \# & $\begin{array}{c}\text { Property } \\
\text { Units }\end{array}$ & Specific requirements & Approach & Data gap impact & Notes \\
\hline \multicolumn{6}{|c|}{ Metrics for technical performance and physical and chemical characteristics criterion } \\
\hline 1 & $\begin{array}{l}\text { Absorption Capacity } \\
\qquad \begin{array}{c}\mathrm{mol} / \mathrm{m}^{3} \text { absorbent } \\
\text { liquid }\end{array}\end{array}$ & $\begin{array}{l}\text { Maximum capacity of scrub } \\
\text { solution as a function of } \mathrm{CO}_{2} \\
\text { concentration, temperature, and } \\
\text { gas velocity. } \\
\text { - } \quad \text { Gas velocities from } 0.18 \text { to } \\
\quad 10 \mathrm{~m} / \mathrm{min} \\
\text { - } \quad \text { Operating temperature } \\
\text { range is }-10^{\circ} \mathrm{C}-50^{\circ} \mathrm{C} \\
-\quad \mathrm{CO}_{2} 7.1 \times 10^{-4} \mathrm{~kg} / \mathrm{m}^{3} \\
-\quad \mathrm{CO} \text { not known }\end{array}$ & $\begin{array}{l}\text { Chemical equilibrium } \\
\text { modeling and detailed } \\
\text { scrubber design; } \\
\text { demonstrated in pilot- } \\
\text { scale tests. }\end{array}$ & Equipment size & \\
\hline 2 & $\begin{array}{l}\text { Capture removal } \\
\text { rates for primary } \\
\text { species } \\
\text { Mol/m } m^{3} \text { absorbent } \\
\text { liquid/h }\end{array}$ & $\begin{array}{l}\text { Adsorption rate data as function } \\
\text { of } \mathrm{CO}_{2} \text { concentration, } \\
\text { temperature, and gas velocity. } \\
\text { Recommended experimental } \\
\text { ranges are provided in Gap ID } \\
\# 1 \text {. }\end{array}$ & $\begin{array}{l}\text { Chemical modeling, and } \\
\text { measurement of } \mathrm{CO} \\
\text { removal with changes in } \\
\text { reagents (e.g., } \mathrm{H}_{2} \mathrm{O}_{2} \text { ) and } \\
\text { operating conditions. }\end{array}$ & Equipment size & \\
\hline
\end{tabular}


Data Requirements and Test System Needs for Development of an Integrated Off-Gas Treatment

Table 7. Data gaps for $\mathrm{CO}_{2}$ absorber evaluations (continued)

\begin{tabular}{|c|c|c|c|c|c|}
\hline \# & $\begin{array}{l}\text { Property } \\
\text { Units }\end{array}$ & Specific requirements & Approach & Data gap impact & Notes \\
\hline 3 & $\begin{array}{c}\text { Capacity for other } \\
\text { species present in gas } \\
\text { stream } \\
\mathrm{mol} / \mathrm{m}^{3} \text { absorbent } \\
\text { liquid }\end{array}$ & 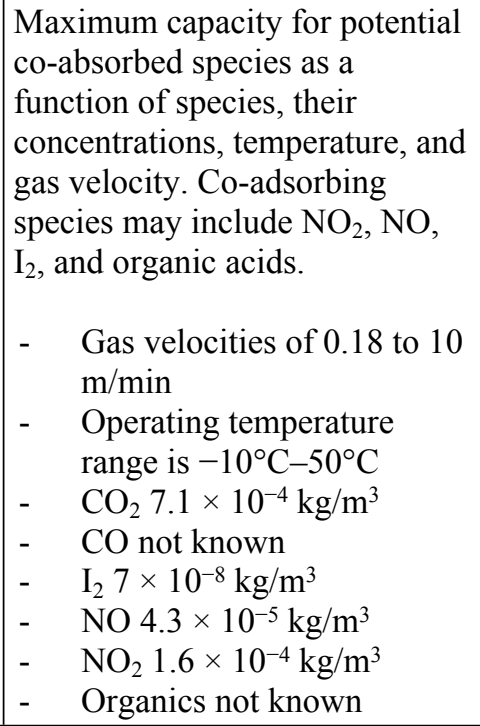 & $\begin{array}{l}\text { Column scrubber tests } \\
\text { and/or column } \\
\text { engineering models. Tests } \\
\text { with steam stripping, } \\
\mathrm{H}_{2} \mathrm{O}_{2} \text { addition or other } \\
\text { techniques. }\end{array}$ & $\begin{array}{l}\text { Equipment } \\
\text { size/operational } \\
\text { sequencing }\end{array}$ & $\begin{array}{l}\text { Escape of less easily scrubbed } \mathrm{NO} \text { from } \mathrm{NO}_{\mathrm{x}} \\
\text { scrubber; organic compounds, esp. organic } \\
\text { acids. }\end{array}$ \\
\hline 4 & $\begin{array}{l}\text { Capture rate for co- } \\
\text { absorbed species } \\
\mathrm{Mol} / \mathrm{m}^{3} \text { absorbent } \\
\text { liquid/h }\end{array}$ & $\begin{array}{l}\text { Adsorption rate data for selected } \\
\text { sorbent as function of co- } \\
\text { absorbed species, temperature, } \\
\text { and concentration. } \\
\text { Recommended experimental } \\
\text { ranges and potentially co- } \\
\text { adsorbing species are provided } \\
\text { in Gap ID \#3. }\end{array}$ & $\begin{array}{l}\text { Chemical modeling and } \\
\text { solubility measurements } \\
\text { as required. }\end{array}$ & $\begin{array}{l}\text { Equipment } \\
\text { size/operational } \\
\text { sequencing }\end{array}$ & $\begin{array}{l}\text { Acid, acid gases and iodine likely mass transfer } \\
\text { limited - engineering design. }\end{array}$ \\
\hline
\end{tabular}


Table 7. Data gaps for $\mathrm{CO}_{2}$ absorber evaluations (continued)

\begin{tabular}{|c|c|c|c|c|c|}
\hline \# & $\begin{array}{c}\text { Property } \\
\text { Units } \\
\end{array}$ & Specific requirements & Approach & Data gap impact & Notes \\
\hline 5 & $\begin{array}{c}\text { Change in sorbent } \\
\text { capacity for } \mathrm{CO}_{2} \text { in } \\
\text { presence of other } \\
\text { species present in gas } \\
\text { stream } \\
\text { mol } / \mathrm{m}^{3} \text { absorbent } \\
\text { liquid }\end{array}$ & $\begin{array}{l}\mathrm{CO}_{2} \text { capacity accounting for } \\
\text { potential adverse effects from } \\
\text { co-absorbed species as a } \\
\text { function of species, temperature, } \\
\text { and concentration. } \\
\text { Recommended experimental } \\
\text { ranges and potentially } \\
\text { coasorbing species are provided } \\
\text { in Gap ID \#3. }\end{array}$ & $\begin{array}{l}\text { Chemical modeling and } \\
\text { solubility measurements } \\
\text { as required. }\end{array}$ & Equipment size & $\begin{array}{l}\text { Acid, acid gases and iodine likely mass transfer } \\
\text { limited - engineering design. }\end{array}$ \\
\hline 6 & $\begin{array}{c}\text { Change in } \mathrm{CO}_{2} \\
\text { capture rate in } \\
\text { presence of co- } \\
\text { absorbed species } \\
\mathrm{Mol} / \mathrm{m}^{3} \text { absorbent } \\
\text { liquid/h }\end{array}$ & $\begin{array}{l}\mathrm{CO}_{2} \text { adsorption rate data for } \\
\text { selected sorbent as function of } \\
\text { co-absorbed species, } \\
\text { temperature, and concentration. } \\
\text { Recommended experimental } \\
\text { ranges and potentially co- } \\
\text { adsorbing species are provided } \\
\text { in Gap ID \#3. }\end{array}$ & $\begin{array}{l}\text { Chemical modeling and } \\
\text { solubility measurements } \\
\text { as required. }\end{array}$ & Equipment size & $\begin{array}{l}\text { Acid, acid gases and iodine likely mass transfer } \\
\text { limited_-engineering design. }\end{array}$ \\
\hline 7 & $\begin{array}{c}\text { Selectivity } \\
\left(X_{a} / Y_{a}\right) /\left(X_{b} / Y_{b}\right) \\
\text { (unitless) } \\
\text { Where } X_{a} \text { and } X_{b} \text { are } \\
\text { mol fractions of } \\
\text { species a and } b \\
\text { respectively in the } \\
\text { adsorbed phase, and } \\
Y_{a} \text { and } Y_{b} \text { are mol } \\
\text { fractions of species a } \\
\text { and } b \text { in the bulk phase }\end{array}$ & $\begin{array}{l}\text { Determination of amounts of } \\
\mathrm{CO}_{2} \text { and contaminants that } \\
\text { adsorb (derived from Gap IDs } \\
\# 3-6) .\end{array}$ & $\begin{array}{l}\text { Chemical and engineering } \\
\text { literature. } \\
\text { Laboratory tests and pilot } \\
\text { tests. }\end{array}$ & $\begin{array}{l}\text { Equipment } \\
\text { size/operational } \\
\text { sequencing/ } \\
\text { process safety }\end{array}$ & $\begin{array}{l}\text { Engineering design methods adequate for } \\
\text { primary function. } \\
\text { Effect of long-term buildup of minor } \\
\text { compounds unknown. }\end{array}$ \\
\hline
\end{tabular}


Data Requirements and Test System Needs for Development of an Integrated Off-Gas Treatment

Table 7. Data gaps for $\mathrm{CO}_{2}$ absorber evaluations (continued)

\begin{tabular}{|c|c|c|c|c|c|}
\hline \# & $\begin{array}{l}\text { Property } \\
\text { Units }\end{array}$ & Specific requirements & Approach & Data gap impact & Notes \\
\hline 8 & $\begin{array}{l}\text { Sorbent density } \\
\qquad \mathrm{kg} / \mathrm{m}^{3}\end{array}$ & Density of aqueous solution. & $\begin{array}{l}\text { Direct measurement or } \\
\text { from manufacturer. }\end{array}$ & Equipment size & $\begin{array}{l}\text { Methods exist to estimate aqueous solution } \\
\text { density to high precision. }\end{array}$ \\
\hline 9 & $\begin{array}{l}\text { Sorbent bulk density } \\
\qquad \mathrm{kg} / \mathrm{m}^{3}\end{array}$ & $\begin{array}{l}\text { N/A, liquid is a continuous } \\
\text { phase unless/until buildup of } \\
\text { organics lead to a second liquid } \\
\text { phase. }\end{array}$ & N/A & Equipment size & \\
\hline 10 & $\begin{array}{c}\text { Specific heat capacity } \\
\qquad J / K / k g\end{array}$ & $\begin{array}{l}\text { Specific heat capacity of fresh } \\
\text { and loaded absorbent over range } \\
\text { of operating conditions. } \\
\text { Operating temperature range is } \\
-15^{\circ} \mathrm{C}-50^{\circ} \mathrm{C} \text {. }\end{array}$ & $\begin{array}{l}\text { Direct measurement or } \\
\text { calculation of fresh } \\
\text { sorbent and loaded } \\
\text { sorbent. }\end{array}$ & Heat duty & $\begin{array}{l}\text { Estimated from properties of water and soluble } \\
\text { salts. }\end{array}$ \\
\hline 11 & $\begin{array}{l}\text { Thermal conductivity } \\
\qquad \mathrm{W} / \mathrm{m} / \mathrm{K}\end{array}$ & $\begin{array}{l}\text { Thermal conductivity of } \\
\text { absorbent over range of } \\
\text { operating conditions. } \\
\text { Operating temperature range is } \\
-15^{\circ} \mathrm{C}-50^{\circ} \mathrm{C} \text {. }\end{array}$ & $\begin{array}{l}\text { Calculation with direct } \\
\text { measurement of fresh } \\
\text { sorbent and loaded } \\
\text { sorbent for verification, if } \\
\text { desired. }\end{array}$ & $\begin{array}{l}\text { Heat } \\
\text { duty/operational } \\
\text { sequencing }\end{array}$ & $\begin{array}{l}\text { Estimated from properties of water and soluble } \\
\text { salts. }\end{array}$ \\
\hline 12 & $\begin{array}{l}\text { Radiation stability } \\
\% \text { degradation in } \\
\text { capacity and/or } \\
\text { absorption rate over } \\
\text { time as a function of } \\
\text { radiation exposure }\end{array}$ & $\begin{array}{l}\text { Change in scrubber DF and } \\
\text { absorber capacity as a function } \\
\text { of absorbed dose. }\end{array}$ & $\begin{array}{l}\text { Gamma irradiation of } \\
\text { selected scrubber solution } \\
\text { compositions; } \\
\text { measurement of amounts } \\
\text { of irradiated species and } \\
\text { reaction products, if any, } \\
\text { along with intermittent } \\
\text { evaluation of adsorption } \\
\text { capacity, adsorption rate, } \\
\text { changes in co-adsorption } \\
\text { rates and capacities. }\end{array}$ & $\begin{array}{l}\text { Radiolysis } \\
\text { producing simpler } \\
\text { reactive } \\
\text { molecules or } \\
\text { causing } \\
\text { polymerization of } \\
\text { co-adsorbed } \\
\text { species }\end{array}$ & $\begin{array}{l}\text { Likely little effect on scrubbing solution, but } \\
\text { accumulation of troublesome (esp organic) } \\
\text { compounds is unknown. }\end{array}$ \\
\hline
\end{tabular}


Data Requirements and Test System Needs for Development of an Integrated Off-Gas Treatment System

Table 7. Data gaps for $\mathrm{CO}_{2}$ absorber evaluations (continued)

\begin{tabular}{|c|c|c|c|c|c|}
\hline$\#$ & $\begin{array}{c}\text { Property } \\
\text { Units }\end{array}$ & Specific requirements & Approach & Data gap impact & Notes \\
\hline 13 & $\begin{array}{c}\text { Mechanical stability } \\
\begin{array}{c}\mathrm{N} / \mathrm{mm} \text { (load vs particle } \\
\text { diameter) } \\
\mu \mathrm{g} / \mathrm{m}^{3} \text { loss to gas } \\
\text { stream }\end{array}\end{array}$ & N/A & $\mathrm{N} / \mathrm{A}$ & N/A & \\
\hline 14 & $\begin{array}{l}\text { Thermal stability } \\
\text { \% degradation in } \\
\text { capacity over time at } \\
\text { selected operating } \\
\text { temperature }\end{array}$ & N/A & $\mathrm{N} / \mathrm{A}$ & N/A & \\
\hline 15 & $\begin{array}{l}\text { Chemical stability } \\
\\
\% \text { degradation in } \\
\text { capacity over time as a } \\
\text { function of other } \\
\text { species present in gas } \\
\text { stream }\end{array}$ & N/A & $\mathrm{N} / \mathrm{A}$ & $\mathrm{N} / \mathrm{A}$ & \\
\hline 16 & $\begin{array}{c}\text { Reactivity } \\
\text { Compatibility as } \\
\text { determined by } \\
\text { standardized } \\
\text { compatibility tables }\end{array}$ & $\begin{array}{l}\text { Confirmation that any } \\
\text { compatibility issues can be } \\
\text { avoided through selection of } \\
\text { materials of construction, } \\
\text { appropriate pretreatment of gas } \\
\text { stream, operational envelope, } \\
\text { etc. }\end{array}$ & Direct evaluation & Equipment life & \\
\hline 17 & $\begin{array}{c}\text { Regeneration } \\
\text { No. of cycles before } \\
\text { degrading to } 80 \% \text { of } \\
\text { capacity for the target } \\
\text { element }\end{array}$ & $\mathrm{N} / \mathrm{A}$ & N/A & N/A & $\begin{array}{l}\text { Caustic is added as needed to maintain required } \\
\text { concentration, and some take-off is needed to } \\
\text { expel excess water from time to time. } \\
\text { Accumulation of organics is the main concern. }\end{array}$ \\
\hline
\end{tabular}


Data Requirements and Test System Needs for Development of an Integrated Off-Gas Treatment

Table 7. Data gaps for $\mathrm{CO}_{2}$ absorber evaluations (continued)

\begin{tabular}{|c|c|c|c|c|c|}
\hline \# & $\begin{array}{c}\text { Property } \\
\text { Units }\end{array}$ & Specific requirements & Approach & Data gap impact & Notes \\
\hline 18 & $\begin{array}{l}\text { Desorption rate of } \\
\mathrm{CO}_{2} \text { during post } \\
\text { loading purge } \\
\mathrm{mol} / \mathrm{m}^{3} \text { absorbent } \\
\text { liquid } / \mathrm{h}\end{array}$ & N/A & N/A & N/A & This metric/gap not considered for scrubbers. \\
\hline 19 & $\begin{array}{l}\text { Desorption of co- } \\
\text { adsorbed species } \\
\text { mol co-adsorbed } \\
\text { species retained/ } \text { m }^{3} \\
\text { absorbent liquid }\end{array}$ & N/A & N/A & N/A & This metric/gap not considered for scrubbers. \\
\hline 20 & $\begin{array}{l}\text { Desorption rate of co- } \\
\text { adsorbed species } \\
\text { mol/m } \mathrm{m}^{3} \text { absorbent } \\
\text { liquid/h }\end{array}$ & N/A & N/A & N/A & This metric/gap not considered for scrubbers. \\
\hline 21 & $\begin{array}{l}\text { Purity of desorbed } \\
\mathbf{C O}_{2} \text { streams } \\
\text { ppm or } \% \mathrm{CO}_{2}\end{array}$ & N/A & N/A & N/A & This metric/gap not considered for scrubbers. \\
\hline 22 & $\begin{array}{c}\text { Cooling time } \\
h\end{array}$ & N/A & N/A & N/A & This metric/gap not considered for scrubbers. \\
\hline \multicolumn{6}{|c|}{ Metrics for system design and performance criterion } \\
\hline 23 & $\begin{array}{c}\text { Pressure drop } \\
\mathrm{Pa} / \mathrm{m} \text { vs } \mathrm{m}^{2} \text { column }\end{array}$ & $\begin{array}{l}\text { Size columns and sorbent } \\
\text { particle size for }<2.5 \mathrm{kPa} \\
\text { pressure drop based on expected } \\
\text { gas flow rates. }\end{array}$ & $\begin{array}{l}\text { Direct measurement or } \\
\text { scaled derivation. }\end{array}$ & $\begin{array}{l}\text { Operational } \\
\text { sequencing/ } \\
\text { equipment size }\end{array}$ & \\
\hline
\end{tabular}


Data Requirements and Test System Needs for Development of an Integrated Off-Gas Treatment System

Table 7. Data gaps for $\mathrm{CO}_{2}$ absorber evaluations (continued)

\begin{tabular}{|c|c|c|c|c|c|}
\hline \# & $\begin{array}{c}\text { Property } \\
\text { Units } \\
\end{array}$ & Specific requirements & Approach & Data gap impact & Notes \\
\hline 24 & $\begin{array}{c}\text { Decontamination } \\
\text { factor (DF) } \\
{\left[\mathrm{CO}_{2}\right]_{\text {inlet }}\left[\mathrm{CO}_{2}\right]_{\text {outlet }}} \\
\text { (unitless) }\end{array}$ & $\begin{array}{l}\text { Overall DF dependent on } \\
\text { equivalent number of theoretical } \\
\text { stages and solubility equilibria. } \\
\text { Shifts in equilibria may be } \\
\text { effected by addition of } \mathrm{H}_{2} \mathrm{O}_{2} \text {. } \\
\text { Gas velocities of } 0.18 \text { to } 10 \\
\mathrm{~m} / \mathrm{min} \text {, determined by design. } \\
\text { Operating temperature range is } \\
-10^{\circ} \mathrm{C}-50^{\circ} \mathrm{C}\end{array}$ & $\begin{array}{l}\text { Calculation/engineering } \\
\text { design. }\end{array}$ & $\begin{array}{l}\text { Equipment } \\
\text { size/operational } \\
\text { sequencing }\end{array}$ & \\
\hline 25 & $\begin{array}{c}\text { Height of a } \\
\text { theoretical stage } \\
m\end{array}$ & $\begin{array}{l}\text { Height of a theoretical stage as a } \\
\text { function of gas velocity, target } \\
\text { species concentration, operating } \\
\text { temperature, and presence of co- } \\
\text { absorbed species shown to have } \\
\text { impact on total capacity or } \\
\text { absorption rate }>10 \% \text {. } \\
\text { Same gas velocities and } \\
\text { temperatures as Gap ID } \# 25 \text {. }\end{array}$ & $\begin{array}{l}\text { Calculation/engineering } \\
\text { design. }\end{array}$ & Equipment size & \\
\hline 26 & $\begin{array}{c}\text { Liquid } \\
\text { volume/holdup } \\
m^{3}\end{array}$ & $\begin{array}{l}\text { Determination of required } \\
\text { system liquid inventory (holdup) } \\
\text { necessary to ensure acceptable } \\
\text { removal characteristics. Based } \\
\text { on calculated diameter and } \\
\text { height of tower. }\end{array}$ & $\begin{array}{l}\text { Engineering } \\
\text { design/operability choice. }\end{array}$ & Equipment size & $\begin{array}{l}\text { Footprint and height of scrubber to be } \\
\text { calculated. }\end{array}$ \\
\hline
\end{tabular}




\section{6 $\mathrm{Kr} / \mathrm{Xe}$ recovery systems}

The Engineering Evaluation identified a lack of pertinent engineering data, such as the adsorption properties, desorption properties, effects of co-adsorbed species and sorbent stability over multiple cycles on solid sorbents for the removal of xenon and krypton. These data are critical to accurately design capture systems using solid sorbent materials for separation of xenon and krypton.

Table 7 summarizes the data gaps and requirements for the $\mathrm{Xe} / \mathrm{Kr}$ solid phase separation system. These gaps follow the same structure as described in the criteria report but focus primarily on the properties of the sorbent materials and key operational parameters.

The most important data gap to be filled for the $\mathrm{Xe} / \mathrm{Kr}$ system is to obtain data on the desorption properties of the $\mathrm{Xe} / \mathrm{Kr}$ sorbents (Gap ID \#18). The next most critical is the determination of the purity of the desorbed streams and their impact on the final waste stream compositions (Gap ID \#21). Also of importance is the determination of the sorbent stabilities over multiple regenerations and exposures to radiation (Gap ID \#12 and \#17). Addressing these gaps will allow a significant refinement in the design of the $\mathrm{Xe} / \mathrm{Kr}$ capture system.

The second tier data gaps include the determination of the adsorption properties (Gap ID \#1-6) as these will aid in the determination of the required length of the bed to achieve the desired $\mathrm{Xe} / \mathrm{Kr} \mathrm{DF}$.

Because of the nature of the $\mathrm{Kr} / \mathrm{Xe}$ adsorption systems, deep-bed testing is required to acquire the desired data. It is envisioned many of these gaps will be investigated using the multicolumn deep-bed testing system. As the technology advances, integration with other unit operations or the ability to produce complex feed streams will be required.

The thermal properties, mechanical stability, and chemical stability data gaps are considered a lower priority at this time. 
Table 8. Data gaps for $\mathrm{Kr} / \mathrm{Xe}$ sorbent evaluations

\begin{tabular}{|c|c|c|c|c|c|}
\hline \# & $\begin{array}{c}\text { Property } \\
\text { Unit }\end{array}$ & Specific requirements & Approach & Data gap impact & Notes \\
\hline \multicolumn{6}{|c|}{ Metrics for technical performance and physical and chemical characteristics criterion } \\
\hline 1 & $\begin{array}{c}\text { Capacity } \\
\text { mmol/kg sorbent }\end{array}$ & $\begin{array}{l}\text { Maximum adsorption capacity } \\
\text { and initial breakthrough time for } \\
\mathrm{Kr} / \mathrm{Xe} \text { on selected sorbent } \\
\text { material as a function of } \mathrm{Kr} \text { and } \\
\text { Xe concentration, operating } \\
\text { temperature, flow rate, and } \\
\text { pressure. } \\
\text { - } \quad \mathrm{Kr} \text { concentration range of } \\
\text { interest is } 0.004 \%-100 \% \\
\text { - } \quad \text { Xe concentration of interest } \\
\text { is } 0.04 \%-100 \% \\
\text { - Temperature range is } \\
-80^{\circ} \mathrm{C}-37^{\circ} \mathrm{C} \\
\text { - Gas velocities of } 0.18- \\
10 \mathrm{~m} / \text { min. } \\
\text { - Pressure swing ranges } \\
\text { requires optimization }\end{array}$ & $\begin{array}{l}\text { Deep-bed tests using } \\
\text { selected sorbent. Both } \\
\text { temperature and pressure } \\
\text { swing operations are } \\
\text { required. }\end{array}$ & Equipment size & $\begin{array}{l}\mathrm{Kr} \text { data gathered for HZ-PAN up to } 4 \% \text { in } \\
\mathrm{He} \text {, up to } 0.015 \% \text { in air } \\
\text { Xe data gathered for HZ-PAN up to } 0.5 \% \\
\text { in He, up to } 0.15 \% \text { in air } \\
\mathrm{Kr} \text { data gathered for Ag-PAN up to } 4 \% \text { in } \\
\text { He, up to } 0.015 \% \text { in air } \\
\text { Xe data gathered for Ag-PAN up to } 0.5 \% \\
\text { in He, up to } 0.15 \% \text { in air } \\
\text { Data gathered for MOF over limited } \\
\text { experimental ranges }\end{array}$ \\
\hline 2 & $\begin{array}{l}\text { Capture/ rate for } \\
\text { primary species } \\
\mathrm{mmol} / \mathrm{kg} \text { sorbent/h }\end{array}$ & $\begin{array}{l}\text { Adsorption rate data for selected } \\
\text { sorbent as function of, } \mathrm{Kr} \text { and } \mathrm{Xe} \\
\text { concentration operating } \\
\text { temperature, flow rate and } \\
\text { pressure. } \\
\text { Recommended experimental } \\
\text { ranges are provided in Gap ID \#1. }\end{array}$ & $\begin{array}{l}\text { Deep-bed tests using } \\
\text { selected sorbent. Both } \\
\text { temperature and pressure } \\
\text { swing operations are } \\
\text { required. }\end{array}$ & Equipment size & $\begin{array}{l}\text { Data may be obtained from existing deep-bed } \\
\text { testing of HZ-PAN, AgZ-PAN. Further deep- } \\
\text { bed testing required for MOFs. }\end{array}$ \\
\hline
\end{tabular}


Data Requirements and Test System Needs for Development of an Integrated Off-Gas Treatment

Table 8. Data gaps for $\mathrm{Kr} / \mathrm{Xe}$ sorbent evaluations (continued)

\begin{tabular}{|c|c|c|c|c|c|}
\hline \# & $\begin{array}{c}\text { Property } \\
\text { Unit }\end{array}$ & Specific requirements & Approach & Data gap impact & Notes \\
\hline 3 & $\begin{array}{l}\text { Capacity for other } \\
\text { species present in } \\
\text { gas stream } \\
\mathrm{mmol} / \mathrm{kg} \text { sorbent }\end{array}$ & 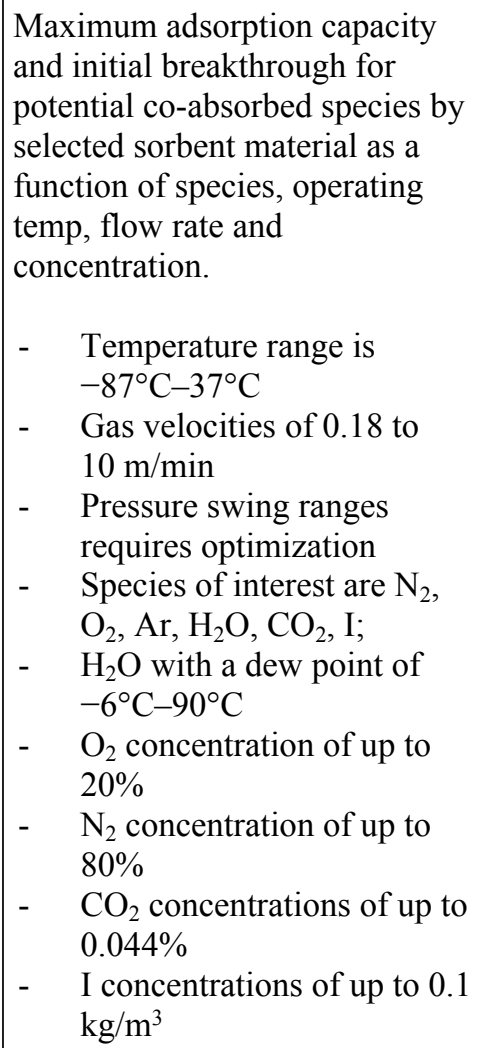 & $\begin{array}{l}\text { Deep-bed tests using } \\
\text { selected sorbent. } \\
\text { Both temperature and } \\
\text { pressure swing operations. }\end{array}$ & $\begin{array}{l}\text { Equipment } \\
\text { size/operational } \\
\text { sequencing }\end{array}$ & $\begin{array}{l}\text { Data for a mixture of } \mathrm{N}_{2} / \mathrm{O}_{2} \text { is available from } \\
\text { deep-bed testing of } \mathrm{HZ} \text {-PAN, } \mathrm{AgZ}-\mathrm{PAN} \text {. } \\
\text { Limited } \mathrm{H}_{2} \mathrm{O} \text { data are available. Thin-bed test } \\
\text { data are available for } \mathrm{MOF} \text { for } \mathrm{N}_{2}, \mathrm{O}_{2}, \mathrm{H}_{2} \mathrm{O} \text {, } \\
\text { and } \mathrm{CO}_{2} \text {. } \\
\text { The combination of } \mathrm{N}_{2} \text { and } \mathrm{O}_{2} \text { are of primary } \\
\text { concern due to overwhelming amounts. It may } \\
\text { not be necessary to test for each individually. } \\
\text { At minimum, } \mathrm{H}_{2} \mathrm{O} \text { should be included in future } \\
\text { sorbent testing. }\end{array}$ \\
\hline
\end{tabular}


Table 8. Data gaps for $\mathrm{Kr} / \mathrm{Xe}$ sorbent evaluations (continued)

\begin{tabular}{|c|c|c|c|c|c|}
\hline \# & $\begin{array}{c}\text { Property } \\
\text { Unit }\end{array}$ & Specific requirements & Approach & Data gap impact & Notes \\
\hline 4 & $\begin{array}{c}\text { Capture rate for } \\
\text { co-absorbed } \\
\text { species }\end{array}$ & $\begin{array}{l}\text { Adsorption rate data for selected } \\
\text { sorbent as function of co- } \\
\text { absorbed species concentration, } \\
\text { operating temp, flow rate and } \\
\text { concentration. } \\
\text { Recommended experimental } \\
\text { ranges and species of interest are } \\
\text { provided in Gap ID \#3. }\end{array}$ & $\begin{array}{l}\text { Deep-bed tests using } \\
\text { selected sorbent. }\end{array}$ & $\begin{array}{l}\text { Equipment } \\
\text { size/operational } \\
\text { sequencing }\end{array}$ & Same as \#3 \\
\hline 5 & $\begin{array}{l}\text { Change in sorbent } \\
\text { capacity for } \mathbf{K r} \text {, } \\
\text { Xe in presence of } \\
\text { other species } \\
\text { present in gas } \\
\text { stream } \\
\mathrm{mmol} / \mathrm{kg} \text { sorbent }\end{array}$ & $\begin{array}{l}\mathrm{Kr} / \text { Xe capacity of selected } \\
\text { sorbent material in the presence } \\
\text { of co-absorbed species as a } \\
\text { function of species, operating } \\
\text { temp, flow rate and } \\
\text { concentration. } \\
\text { Recommended experimental } \\
\text { ranges and species of interest are } \\
\text { provided in Gap ID \#3. }\end{array}$ & $\begin{array}{l}\text { Deep-bed tests using } \\
\text { selected sorbents. }\end{array}$ & Equipment size & Same as \#3. \\
\hline 6 & $\begin{array}{l}\text { Change in } \mathrm{Kr}, \mathrm{Xe} \\
\text { capture rate in } \\
\text { presence of co- } \\
\text { absorbed species } \\
\mathrm{mmol} / \mathrm{kg} \text { sorbent } / \mathrm{h}\end{array}$ & $\begin{array}{l}\mathrm{Kr} / \text { Xe adsorption rate data for } \\
\text { selected sorbent as function of co- } \\
\text { absorbed species, operating temp, } \\
\text { and concentration. } \\
\text { Recommended experimental } \\
\text { ranges and species of interest are } \\
\text { provided in Gap ID \#3. }\end{array}$ & $\begin{array}{l}\text { Deep-bed tests using } \\
\text { selected sorbents. }\end{array}$ & Equipment size & $\begin{array}{l}\text { Data gathered during cycling and regeneration } \\
\text { tests. }\end{array}$ \\
\hline 7 & $\begin{array}{c}\text { Selectivity } \\
\left(X_{a} / Y_{a}\right) /\left(X_{b} / Y_{b}\right) \\
\text { (unitless) }\end{array}$ & $\begin{array}{l}\text { Derived from data on co- } \\
\text { absorption studies shown above. }\end{array}$ & $\begin{array}{l}\text { Deep-bed tests using } \\
\text { selected sorbent. }\end{array}$ & $\begin{array}{l}\text { Equipment } \\
\text { size/operational } \\
\text { sequencing }\end{array}$ & \\
\hline
\end{tabular}


Data Requirements and Test System Needs for Development of an Integrated Off-Gas Treatment

Table 8. Data gaps for Kr/Xe sorbent evaluations (continued)

\begin{tabular}{|c|c|c|c|c|c|}
\hline$\#$ & $\begin{array}{l}\text { Property } \\
\text { Unit }\end{array}$ & Specific requirements & Approach & Data gap impact & Notes \\
\hline 8 & $\begin{array}{c}\begin{array}{c}\text { Sorbent particle } \\
\text { density }\end{array} \\
\mathrm{kg} / \mathrm{m}^{3} \text { sorbent }\end{array}$ & $\begin{array}{l}\text { Density of individual particles in } \\
\mathrm{kg} / \mathrm{m}^{3} \text {. }\end{array}$ & Direct measurement. & Equipment size & $\begin{array}{l}\text { Completed for HZ-PAN, AgZ-PAN, CaSDB } \\
\text { MOF. }\end{array}$ \\
\hline 9 & $\begin{array}{l}\begin{array}{c}\text { Sorbent bulk } \\
\text { density }\end{array} \\
\mathrm{kg} / \mathrm{m}^{3} \text { sorbent }\end{array}$ & $\begin{array}{l}\text { Bulk density of bed of sorbent } \\
\text { material in typical loading } \\
\text { configuration in } \mathrm{kg} / \mathrm{m}^{3} \text {. }\end{array}$ & Direct measurement. & Equipment size & $\begin{array}{l}\text { Completed for HZ-PAN, AgZ-PAN, CaSDB } \\
\text { MOF. However, this will change somewhat } \\
\text { based on sorbent particle size chosen based on } \\
\text { column design. }\end{array}$ \\
\hline 10 & $\begin{array}{c}\begin{array}{c}\text { Specific heat } \\
\text { capacity }\end{array} \\
\mathrm{J} / \mathrm{K} / \mathrm{kg} \text { or } \mathrm{J} / \mathrm{K} / \mathrm{m}^{3}\end{array}$ & $\begin{array}{l}\text { Specific heat capacity of fresh } \\
\text { and loaded sorbent over range of } \\
\text { operating conditions. } \\
\text { Operating temperature range is } \\
-80^{\circ} \mathrm{C}-150^{\circ} \mathrm{C} \text {. }\end{array}$ & $\begin{array}{l}\text { Direct measurement of } \\
\text { fresh and loaded sorbent. }\end{array}$ & Heat duty & $\begin{array}{l}\text { Currently estimated for HZ-PAN, AgZ-PAN } \\
\text { based on published data for individual } \\
\text { components of the composite material. }\end{array}$ \\
\hline 11 & $\begin{array}{c}\begin{array}{c}\text { Thermal } \\
\text { conductivity }\end{array} \\
\mathrm{W} / \mathrm{m} / \mathrm{K}\end{array}$ & $\begin{array}{l}\text { Thermal conductivity of sorbent } \\
\text { over range of operating } \\
\text { conditions. } \\
\text { Operating temperature range is } \\
-80^{\circ} \mathrm{C}-150^{\circ} \mathrm{C} \text {. }\end{array}$ & $\begin{array}{l}\text { Direct measurement of } \\
\text { fresh and loaded sorbent. }\end{array}$ & $\begin{array}{l}\text { Heat } \\
\text { duty/operational } \\
\text { sequencing }\end{array}$ & $\begin{array}{l}\text { Currently estimated for HZ-PAN, AgZ-PAN } \\
\text { based on published data for individual } \\
\text { components of the composite material. }\end{array}$ \\
\hline 12 & $\begin{array}{c}\text { Radiation stability } \\
\begin{array}{c}\Delta \mathrm{mmol} / \mathrm{kg} \\
\text { sorbent } / \mathrm{k} G y\end{array}\end{array}$ & $\begin{array}{l}\text { \% degradation in capacity and/or } \\
\text { adsorption rate over time as a } \\
\text { function of radiation exposure. } \\
\text { Total cumulative adsorbed dose } \\
\text { for } \mathrm{Kr}, \mathrm{Xe} \text { sorbents is design } \\
\text { dependent. }\end{array}$ & $\begin{array}{l}\text { Gamma and/or beta } \\
\text { irradiation of selected } \\
\text { adsorbent to doses TBD, } \\
\text { along with intermittent } \\
\text { evaluation of adsorption } \\
\text { capacity, adsorption rate, } \\
\text { changes in co-adsorption } \\
\text { rates and capacities. }\end{array}$ & Material life cycle & $\begin{array}{l}\text { Testing has indicated that a high radiation dose } \\
\text { may have an impact on HZPAN and/or } \\
\text { AgZPAN sorbent performance, Further } \\
\text { evaluations will be needed to define what dose } \\
\text { is damaging. }\end{array}$ \\
\hline
\end{tabular}


Table 8. Data gaps for $\mathrm{Kr} / \mathrm{Xe}$ sorbent evaluations (continued)

\begin{tabular}{|c|c|c|c|c|c|}
\hline \# & $\begin{array}{c}\text { Property } \\
\text { Unit }\end{array}$ & Specific requirements & Approach & Data gap impact & Notes \\
\hline 13 & $\begin{array}{c}\text { Mechanical } \\
\text { stability } \\
\text { N/mm (load } v s \\
\text { particle diameter) } \\
\mu g / k g \text { sorbent loss } \\
\text { to gas stream }\end{array}$ & $\begin{array}{l}\text { Determination of the fines } \\
\text { generation and mechanical } \\
\text { strength of the sorbent material. }\end{array}$ & $\begin{array}{l}\text { Direct measurement. } \\
\text { Measurements of both } \\
\text { particle crush strength and } \\
\text { abrasion resistance will be } \\
\text { required. }\end{array}$ & Material life cycle & $\begin{array}{l}\text { Testing of particle crush strength of HZ-PAN, } \\
\text { AgZ-PAN and CaSDB MOF is complete and } \\
\text { deemed sufficient, but not published. } \\
\text { One test of abrasion resistance for HZ-PAN } \\
\text { and AgZ-PAN is complete with no generated } \\
\text { fines. Packed column crush strength has not } \\
\text { been measured. } \\
\text { One test of abrasion resistance for CaSDB } \\
\text { MOF is complete with indication of excessive } \\
\text { fines generation. Further testing/engineered } \\
\text { form modification should be considered. } \\
\text { Packed column crush strength testing has not } \\
\text { been done on any sorbent to date. }\end{array}$ \\
\hline 14 & $\begin{array}{l}\text { Thermal stability } \\
\text { \% degradation in } \\
\text { capacity over time } \\
\text { at selected } \\
\text { operating } \\
\text { temperature }\end{array}$ & $\begin{array}{l}\text { Determine the extent of capacity } \\
\text { loss due to extended exposure to } \\
\text { operating temperature. Determine } \\
\text { the extent of capacity loss due to } \\
\text { thermal cycling and excursions. }\end{array}$ & $\begin{array}{l}\text { Data may be gathered from } \\
\text { existing long-term testing } \\
\text { of selected sorbents } \\
\text { through multiple } \\
\text { adsorption/desorption } \\
\text { cycles. }\end{array}$ & Material life cycle & \\
\hline
\end{tabular}


Table 8. Data gaps for $\mathrm{Kr} / \mathrm{Xe}$ sorbent evaluations (continued)

\begin{tabular}{|c|c|c|c|c|c|}
\hline \# & $\begin{array}{l}\text { Property } \\
\text { Unit }\end{array}$ & Specific requirements & Approach & Data gap impact & Notes \\
\hline 15 & $\begin{array}{l}\text { Chemical stability } \\
\text { \% degradation in } \\
\text { capacity over time } \\
\text { as a function of } \\
\text { other species } \\
\text { present in gas } \\
\text { stream }\end{array}$ & $\begin{array}{l}\text { Determine the extent of capacity } \\
\text { loss due to extended exposure to } \\
\text { other species present in the off- } \\
\text { gas stream. }\end{array}$ & $\begin{array}{l}\text { Extended testing. } \\
\text { Age sorbents for various } \\
\text { lengths of time to elevated } \\
\text { levels of each of the non- } \\
\text { target species expected. } \\
\text { Determine Kr/Xe capacity } \\
\text { and rates of adsorption. } \\
\text { Differences should be } \\
\text { attributable to aging and } \\
\text { should be a function of } \\
\text { exposure time and non- } \\
\text { target species exposure. }\end{array}$ & Material life cycle & $\begin{array}{l}\text { AgZ-PAN, HZ-PAN, and MOF materials } \\
\text { tested to date meet this criterion. }\end{array}$ \\
\hline 16 & $\begin{array}{c}\text { Reactivity } \\
\text { Compatibility as } \\
\text { determined by } \\
\text { standardized } \\
\text { compatibility tables }\end{array}$ & $\begin{array}{l}\text { Confirmation that any } \\
\text { compatibility issues can be } \\
\text { avoided through selection of } \\
\text { materials of construction, } \\
\text { appropriate pretreatment of gas } \\
\text { stream, operational envelope, etc. }\end{array}$ & Direct evaluation. & Material life cycle & $\begin{array}{l}\text { AgZ-PAN, HZ-PAN, and MOF materials } \\
\text { tested to date meet this criterion. }\end{array}$ \\
\hline 17 & $\begin{array}{c}\text { Regeneration } \\
\text { capacity stability } \\
\Delta \mathrm{mmol} / \mathrm{kg} \text { sorbent } \\
\text { /regeneration cycle }\end{array}$ & $\begin{array}{l}\text { No. of cycles before degrading to } \\
80 \% \text { of capacity for the target } \\
\text { element }\end{array}$ & $\begin{array}{l}\text { Long-term, repeated } \\
\text { testing of select sorbent } \\
\text { over multiple } \\
\text { adsorption/desorption } \\
\text { cycles. }\end{array}$ & Material life cycle & $\begin{array}{l}\text { \# of thermal cycles have been reported for } \\
\text { AgZ-PAN under defined temp ranges. }\end{array}$ \\
\hline 18 & $\begin{array}{l}\text { Desorption rate of } \\
\qquad \mathbf{K r} / \mathbf{X e} \\
\mathrm{mmol} / \mathrm{kg} \text { sorbent } / \mathrm{h}\end{array}$ & $\begin{array}{l}\text { Desorption of } \mathrm{Kr} \text { and } \mathrm{Xe} \text { as a } \\
\text { function of operating } \\
\text { temperature, purge gas flow rate } \\
\text { and pressure. } \\
\text { Recommended experimental } \\
\text { ranges are provided in Gap ID \#1 }\end{array}$ & $\begin{array}{l}\text { Deep-bed tests using } \\
\text { selected sorbent. } \\
\text { Both temperature and } \\
\text { pressure swing operations. }\end{array}$ & $\begin{array}{l}\text { Operational } \\
\text { sequencing }\end{array}$ & Some data are available for existing sorbents. \\
\hline
\end{tabular}


Table 8. Data gaps for $\mathrm{Kr} / \mathrm{Xe}$ sorbent evaluations (continued)

\begin{tabular}{|c|c|c|c|c|c|}
\hline \# & $\begin{array}{c}\text { Property } \\
\text { Unit }\end{array}$ & Specific requirements & Approach & Data gap impact & Notes \\
\hline 19 & $\begin{array}{l}\text { Desorption of co- } \\
\text { adsorbed species } \\
\text { mmol retained } / \mathrm{kg} \\
\quad \text { sorbent }\end{array}$ & $\begin{array}{l}\% \text { of co-adsorbed species } \\
\text { desorbed during selected } \\
\text { regeneration conditions. } \\
\text { Recommended experimental } \\
\text { ranges and potentially co- } \\
\text { adsorbing species are provided in } \\
\text { Gap ID \#3. }\end{array}$ & $\begin{array}{l}\text { Deep-bed tests using } \\
\text { selected sorbent. }\end{array}$ & Equipment size & $\begin{array}{l}\text { Some data may be obtained from existing deep } \\
\text { bed testing of HZ-PAN, AgZ-PAN, but further } \\
\text { testing is required. Further deep bed testing is } \\
\text { required for MOFs. }\end{array}$ \\
\hline 20 & $\begin{array}{l}\begin{array}{c}\text { Desorption rate of } \\
\text { co-adsorbed } \\
\text { species }\end{array} \\
\mathrm{mmol} / \mathrm{kg} \mathrm{sorbent} / \mathrm{h}\end{array}$ & $\begin{array}{l}\text { Desorption rate as a function of } \\
\text { desorption temperature and purge } \\
\text { stream gas velocity. } \\
\text { Recommended experimental } \\
\text { ranges and potentially co- } \\
\text { adsorbing species are provided in } \\
\text { Gap ID \#3. }\end{array}$ & $\begin{array}{l}\text { Deep-bed tests using } \\
\text { selected sorbent collecting } \\
\text { and analyzing the effluent } \\
\text { from the sorbent bed. }\end{array}$ & Material life cycle & $\begin{array}{l}\text { Some data may be obtained from existing deep } \\
\text { bed testing of HZ-PAN, AgZ-PAN, but further } \\
\text { testing is required. Further deep-bed testing is } \\
\text { required for MOFs. }\end{array}$ \\
\hline 21 & $\begin{array}{c}\text { Purity of desorbed } \\
\text { Xe/Kr streams } \\
\text { ppm or } \% \mathrm{Xe} / \mathrm{Kr}\end{array}$ & $\begin{array}{l}\text { Concentrations of the captured } \\
\text { gases desorbed from the sorbent } \\
\text { after loading. } \\
\text { Determination of } \mathrm{Kr} \text { and } \mathrm{Xe} \\
\text { concentration factors and purity. }\end{array}$ & $\begin{array}{l}\text { Deep-bed tests using } \\
\text { selected sorbent. }\end{array}$ & $\begin{array}{l}\text { Operational } \\
\text { sequencing }\end{array}$ & $\begin{array}{l}\text { Preliminary testing has shown this composition } \\
\text { is somewhat difficult to accurately define. }\end{array}$ \\
\hline 22 & $\begin{array}{c}\text { Cooling time } \\
h\end{array}$ & $\begin{array}{l}\text { Hours to cool from regeneration } \\
\text { temperatures to adsorbing } \\
\text { temperatures. }\end{array}$ & $\begin{array}{l}\text { Derived from heat } \\
\text { capacity, thermal } \\
\text { conductivity, and bed } \\
\text { design. }\end{array}$ & Heat duty & $\begin{array}{l}\text { Readily derived and confirmed during deep- } \\
\text { bed testing. }\end{array}$ \\
\hline \multicolumn{6}{|c|}{$\begin{array}{l}\text { Metrics for system design and performance criterion } \\
\end{array}$} \\
\hline 23 & $\begin{array}{c}\text { Pressure drop } \\
\mathrm{kPa} / \mathrm{m} \text { vs } \mathrm{m}^{2} \text { column }\end{array}$ & $\begin{array}{l}\text { Size columns and sorbent particle } \\
\text { size for }<2.5 \mathrm{kPa} \text { pressure drop } \\
\text { based on expected gas flow rates }\end{array}$ & $\begin{array}{l}\text { Direct measurement or } \\
\text { scaled derivation. }\end{array}$ & $\begin{array}{l}\text { Operational } \\
\text { sequencing/ } \\
\text { equipment size }\end{array}$ & \\
\hline
\end{tabular}


Table 8. Data gaps for $\mathrm{Kr} / \mathrm{Xe}$ sorbent evaluations (continued)

\begin{tabular}{|c|c|c|c|c|c|}
\hline \# & $\begin{array}{l}\text { Property } \\
\text { Unit }\end{array}$ & Specific requirements & Approach & Data gap impact & Notes \\
\hline 24 & $\begin{array}{l}\text { Decontamination } \\
\text { factor (DF) } \\
{[\text { Isotope }]_{a} /} \\
{[\text { Isotope }]_{b}} \\
\text { (unitless) }\end{array}$ & $\begin{array}{l}\text { DF data as function of sorbent, } \\
\text { operating temperature, } \mathrm{Kr} / \mathrm{Xe} \\
\text { concentration, time, and bed } \\
\text { depth. } \\
\text { Recommended experimental } \\
\text { ranges are provided in Gap ID \#1. }\end{array}$ & $\begin{array}{l}\text { Deep-bed testing with } \\
\text { online measurement of } \\
\text { inlet and effluent } \mathrm{H}_{2} \mathrm{O} \\
\text { concentrations. } \\
\text { Test system must be able to } \\
\text { hold a deep bed of sorbent } \\
\text { at given temperature and } \\
\text { expose sorbent to a } \\
\text { generated air stream } \\
\text { containing water (and any } \\
\text { potentially co-adsorbed } \\
\text { species) at varying } \\
\text { concentrations within the } \\
\text { specified concentration } \\
\text { range and gas velocity. } \\
\text { Both inlet and effluent gas } \\
\text { streams must be assessed } \\
\text { for Kr/Xe concentration. }\end{array}$ & $\begin{array}{l}\text { Equipment } \\
\text { size/operational } \\
\text { sequencing }\end{array}$ & $\begin{array}{l}\text { This is actually a function of the overall system } \\
\text { design but the ability to demonstrate that the } \\
\text { assumed DF is achievable is needed for a } \\
\text { comparable design. }\end{array}$ \\
\hline 25 & $\begin{array}{l}\text { Length of Mass } \\
\text { Transfer Zone } \\
\text { (MTZ) } \\
m\end{array}$ & $\begin{array}{l}\text { Length of MTZ as a function of } \\
\text { gas velocity, target species } \\
\text { concentration, operating } \\
\text { temperature, and presence of co- } \\
\text { absorbed species shown to have } \\
\text { impact on total capacity or } \\
\text { adsorption rate }>10 \% \text {. } \\
\text { Recommended experimental } \\
\text { ranges are provided in Gap ID \#1. }\end{array}$ & $\begin{array}{l}\text { Deep-bed tests with bed } \\
\text { depth that captures } 1.5 \\
\text { times MTZ. Predictions } \\
\text { can be made from thin-bed } \\
\text { tests and data may also be } \\
\text { determined from DF } \\
\text { testing using deep beds. } \\
\text { (Deep-bed testing: Gap ID } \\
\# 24) \text {. }\end{array}$ & Equipment size & $\begin{array}{l}\text { Derived from deep-bed test breakthrough } \\
\text { curves. }\end{array}$ \\
\hline
\end{tabular}




\section{CONCLUSIONS AND RECOMMENDATIONS}

\subsection{Summary of priority data gaps}

In the development of this report considerable discussion occurred on the lack of data regarding the source terms. During the Engineering Evaluation conducted in FY 2016, the design of a Ru capture system for the TPT system was hindered because of the lack of critical data on Ru generation and speciation. Also, the volatilization of other semi-volatile components from the TPT system was ignored. Better understanding and quantification of the off-gas streams from the TPT - and to a lesser degree the dissolution system - is critical. However critical, such work lies somewhat outside the current scope of the Off-gas Sigma Team. That said, joint studies into this critical interface area should be undertaken at the earliest opportunity.

The Engineering Evaluation pointed out that although considerable progress has been made in developing abatement systems for the four primary volatile radionuclides of interest (i.e., ${ }^{3} \mathrm{H},{ }^{14} \mathrm{C},{ }^{85} \mathrm{Kr}$, and ${ }^{129} \mathrm{I}$ ) much of the data focused on the capacity of the adsorbent or absorbent for the species of interest only and little or no data existed for the co-absorbed species.

For the $\mathrm{Ru}$ sorbents, the most critical gap beyond that of the source term is adsorption capacity and adsorption rate data. Because this may be one of the first adsorption processes in the off-gas train, the coadsorption of other materials in the off-gas stream is also a high priority. The next most important gap to address is the determination of the MTZ and its length.

For tritium, the most substantial data gaps that limit the refinement of the tritium removal system design are related to the co-adsorption/desorption of other off-gas species. Since this is envisioned to be a regenerable system, testing of a multicolumn configuration of the capture and regeneration systems coupled with the tritium recovery, concentration, and solidification processes should be demonstrated in an integrated fashion.

The iodine gaps were divided into gaps for DOG systems and for VOG/air TPT systems. For the DOG system, data on the impact of co-adsorbed species and the length of the MTZ are judged as the most pressing need. Thin- and deep-bed test systems similar to the current systems are required to collect these data. Data on the desorption behavior of co-absorbed species as well as target species should also be a near term priority and should be collected as part of the adsorption testing. For VOG, and air TPTOG systems additional basic adsorption performance data are still needed for design of these iodine sorption systems. For these systems, current R\&D efforts are focused mainly on the adsorption capacity using deep beds for very dilute iodine streams. Because of the time involved in collecting this data, additional tests systems should be established. Obtaining data on the expected efficiency of the iodine sorbents under VOG and air TPT conditions in terms of DF and length of the associated MTZ are also key data needs. Closure of these data gaps requires test systems designed to operate with deep beds and over extended test durations (months to years).

There are fewer data gaps for scrubbers than for the other systems. The Engineering Evaluation drew from existing designs and industrial experience. What may become a gap is the limited experience within the Department of Energy complex to design such systems as very little work has been conducted in this area for two to three decades. The impacts of co-absorbed species, especially from $\mathrm{NO}_{\mathrm{x}}$ and iodine that pass through upstream operations, on the scrubber design and operation and on the waste form also need to be better evaluated.

The most important data gap to be filled for the $\mathrm{Xe} / \mathrm{Kr}$ system is to obtain data on the desorption properties of the $\mathrm{Xe} / \mathrm{Kr}$ sorbents. The next most critical is the determination of the purity of the desorbed streams and their impact on the final waste stream compositions. Also of importance is the determination 
of the sorbent stabilities over multiple regenerations and exposures to radiation. Addressing these gaps will allow a significant refinement in the design of the $\mathrm{Xe} / \mathrm{Kr}$ capture system.

\subsection{Common elements}

\subsubsection{Capacity and adsorption rate}

Capacity and adsorption rate data needs appear common for all the unit operations considered. These two parameters dictate the dimensions and operating conditions of the sorbent beds and wet scrubber systems. The capacity dictates the mass and volume of $\mathrm{Ru}, \mathrm{I}$, and $\mathrm{Kr} / \mathrm{Xe}$ sorbent beds for a given adsorption duration; the adsorption rate dictates the needed depth of the solid sorbent beds and the height of the wet scrubbers. The capacity of the solid sorbents and the scrubber solutions also dictates the mass and volume of spent sorbents and scrub solutions for recycle or disposal. The maturity and quality of the engineering designs and process operating conditions are only as good as the quality of these data for the specific applications.

Continued R\&D as summarized in this document is needed to mature the capture technologies as well as design and operate capture systems that use these technologies. The needed R\&D generally includes laboratory and small pilot-scale thin-bed and deep-bed solid sorbent testing to expand the range of tests completed to date; and eventually scaled up to integrated systems using representative synthetically generated gas mixtures or slip-streams off of operating reprocessing facilities.

\subsubsection{Co-adsorption of non-target species}

Co-adsorption of other species is important to the extent that it interferes with the adsorption of the target species, impacts process operation, or impacts handling, recycle, or disposal of the spent sorbent/scrub solutions, and the waste form and disposal of the captured species. This is of secondary importance compared to demonstrating and optimizing capacity and adsorption rates for the target species; but coadsorption and impacts of co-adsorption are areas where generally even less is currently known for both sorbent beds and wet scrubber systems. Co-adsorption data and impacts of co-adsorption on the adsorption and waste form/disposal processes should be obtained in parallel with maturing the adsorption technologies for the target species. Desorption tests may require larger, more complex test beds to provide suitable simulated feed streams and the subsequent desorption, effluent sampling, and sample analysis of the associated co-adsorbed species.

\subsubsection{Sorbent physical properties data}

Sorbent particle and bulk densities impact the volume of the adsorption system for a given mass of sorbent. Although these are important parameters for sizing sorbent bed systems, obtaining these data does not require extensive test programs.

\subsubsection{Regenerable systems}

For regenerable systems, data on desorption and multicycle operations is also critical for the sizing of the subsequent recovery systems, the design of any additional purification, and the conversion to a waste form. In general, obtaining this type of data requires larger, more complex test beds and must deal with co-adsorbed species, which are needed for regenerable sorbents like those being tested for $\mathrm{Kr}$ and $\mathrm{Xe}$ capture, and scrub solution for $\mathrm{CO}_{2}$ that is recycled back to the scrubber after precipitating out the captured $\mathrm{CO}_{2}$. Considerable uncertainty exists in how to engineer regeneration systems for $\mathrm{Kr}$ and $\mathrm{Xe}$ capture, considering (1) expected height and footprint limitations, and (2) how to implement regeneration using either pressure, temperature, or combined pressure-temperature swing systems. Regenerable sorbents and sorbent beds must be able to operate in the process for potentially orders of magnitude longer time than non-regenerable sorbents. The design and operation of thermal swing regeneration systems must rely on heat transfer constraints imposed by sorbent heat capacities and thermal 
conductivities and account for thermal, mechanical, chemical, and radiation stabilities over the design temperature ranges. Mechanical, chemical, and radiation stabilities also apply, along with designs for pressure and radiological control, to pressure swing systems.

The general maturity level of wet scrubber systems is high. $\mathrm{NO}_{\mathrm{x}}$ and $\mathrm{CO}_{2}$ scrubber systems can be designed using standard wet scrubber engineering design, with adaptations from references cited in this report. However, the actual use of these technologies in aqueous reprocessing dissolver off-gas applications has been limited in the United States. Uncertainties in actual process efficiencies, impacts of co-adsorbed species, and the properties and amounts of the resultant nitric acid recycle and carbonate disposal streams will need to be resolved to mature these technologies for these specific applications.

\subsection{Integrated testing}

Many of the data gaps identified in this report can be effectively addressed with test systems focused on specific target component. In the case of regenerable sorbents that focus on tritium, $\mathrm{Xe}$, and $\mathrm{Kr}$, more complex test beds will be required to obtain data on the desorption behavior, co-absorbed species, potential product purification, and cycle time systems. In the case of $\mathrm{Xe}$ and $\mathrm{Kr}$, some preconditioning of the gas streams may also be required in an actual plant design. These systems should be integrated with the $\mathrm{Xe} / \mathrm{Kr}$ capture systems.

Integrated test beds should also be designed that couple the tritium capture and recovery systems and iodine capture systems with the Ru abatement system. This should be completed for both the TPTOG stream conditions as well as the dissolver off-gas system conditions, with a focus on the long-term effects of water vapor on the Ru recovery system and the potential accumulation of $\mathrm{Ru}$ within the tritium capture systems. Of importance is the evaluation of the long-term effects of water vapor on the Ru sorbent, the contribution of the back-flushable filters and HEPA filters to the overall Ru DF, and the selective recovery of tritium-contaminated water for conversion to a stable waste form.

Ultimately a fully integrated cold or tracer level off-gas test would be needed to validate any design for a future reprocessing plant. Before the design of such a system many of the data gaps identified in this report must be closed. 


\section{REFERENCES}

Bruffey, S. H., B. B. Spencer, D. M. Strachan, R. T. Jubin, N. Soelberg, and B. J. Riley, 2015, “A Literature Survey to Identify Potentially Problematic Volatile Iodine-Bearing Species Present in Off-Gas Streams,"FCR\&D-MRWFD-2015-000421, ORNL-SPR-2015/290, INL/EXT-15-35609, 30 June.

Counce, R. M. and Groenier, W. S., 1978. Nitrogen Oxide Absorption into Water and Dilute Nitric Acid-Description of a Mathematical Model and Preliminary Scrubbing Results Using an EngineeringScale Sieve-Plate Column, ORNL/TM-5910, Oak Ridge National Laboratory, July 1978. (Applied Technology).

Counce, R. M.,1978. Nitrogen Oxide Absorption into Water and Dilute Nitric Acid in an EngineeringScale Sieve-Plate Column-Description of a Mathematical Model and Comparison with Experimental Data, ORNL-5438, Oak Ridge National Laboratory, September 1978. (Applied Technology).

Counce, R. M. and Perona, J. J.,1980. "A Mathematical Model for Nitrogen Oxide Absorption in a SievePlate Column," I\&EC Process Design and Development, vol 19, pp 426-431, July 1980.

Counce, R. M. and Perona, J. J.,1979a. "Gas-Liquid Interfacial Area of a Sieve-Plate with Downcomers and 0.6\% Perforation," I\&EC Process Design and Development, vol 18, pp 562-564, July 1979.

Counce, R. M. and Perona, J. J.,1979b. "Gaseous Nitrogen Oxide Absorption in a Sieve-Plate Column" I\&EC Fundamentals, vol 18, no. 4, pp 400-406, November 1979.

Counce, R. M., 1979. A User's Manual to ABNOX, a Computer Program Designed to Simulate the Nitrogen Oxide Removal Efficiency of a Multistage Bubble-Cap Tower, ORNL/TM-6938, Oak Ridge National Laboratory, September 1979.

Counce, R. M., 1980. The Scrubbing of Gaseous Nitrogen Oxides in Packed Towers, ORNL-5676, Oak Ridge National Laboratory, November 1980.

Jubin, R. T., D. W. Ramey, R. S. Owens, J. M. Giaquinto, E. S. Meyers, B. B. Spencer, and G. D. Del Cul, (2009) "Voloxidation Off-Gas Capture: Experimental Results from Processing of CETE Run 2 Fuels, Report No. ORNL/TM-2009/187. Oak Ridge National Laboratory, Oak Ridge, TN. (DRAFT).

Jubin, R. T., Jordan, J. A., Spencer, B. B., Soelberg, N. R., Welty, A. K., Greenhalgh, M., Strachan, D. M., Thallapally, P. K. 2016a. Engineering Evaluation of an Integrated Off-Gas Treatment System for Used Nuclear Fuel Reprocessing Facilities. Report No. FCRD-MRWFD-2016-000313, Oak Ridge, TN: UT-Battelle, LLC, Oak Ridge National Laboratory.

Jubin, R. T., S. H. Bruffey, D. M. Strachan, N. R. Soelberg, and B. B. Spencer, and B. J. Riley, 2016b, "Performance Criteria for Capture and/or Immobilization Technologies," FCRD-MRWFD-2016-000533, ORNL/TM/2016-73, February, 2016.

Jubin, R. T., D. M. Strachan, and N.R. Soelberg, 2013, “Iodine Pathways and Off-Gas Stream Characteristics Characteristics for Aqueous Reprocessing Plants - A Literature Survey and Assessment," FCRD-SWF-2013-000308, ORNL/LTR-2013/383, INL/EXT-13-30119, September 15.

Jubin, R. T., N. R. Soelberg, D. M. Strachan, and G. Ilas. 2012. Fuel Age Impacts on Gaseous Fission Product Capture during Separations. Report No. FCRD-SWF-2012-000089, Oak Ridge, TN: UTBattelle, LLC, Oak Ridge National Laboratory.

Jubin, R. T. and B. B. Spencer. 2017. Evaluation of Tritium Management Approaches on Tritium Waste Volumes in Reprocessing Plants. Report No. NTRD-MRWFD-2017-000267 and ORNL/TM-2017/307, Oak Ridge, TN: UT-Battelle, LLC, Oak Ridge National Laboratory. 
Law, J., N. Soelberg, T. Todd, G. Fredrickson, S. Frank, (INL), C. Pereira, M. Williamson, W. Ebert, J. Willit (ANL), R. Jubin, (ORNL), J. Vienna, G. Lumetta, J. Crum (PNNL), T. Rudisill (SRNL), J. Bresee (DOE-NE), C. Phillips, B. Willis (EnergySolutions), S. Bader (AREVA), 2015, "Separation and Waste Form Campaign Full Recycle Case Study,” FCRD-MRWFD-2015-000241, September 30.

Meleshyn, A. and Noseck, U., 2012. Radionuclide Inventory of Vitrified Waste after Spent Nuclear Fuel Reprocessing at La Hague, GRS-294, Gesellschaft für Anlagen-und Reaktorsicherheit, September 2012.

Nenoff, T., M. Rodriguez, N. Soelberg, K. Chapman, 2014, "Silver-Mordenite for Radiologic Gas Capture from Complex Streams: Dual Catalytic CH3I Decomposition and I Confinement," Microporous and Mesoporous Materials, MICMAT6530, INL/JOU-14-31276, 9 May.

Soelberg, N. R., T. G. Garn, M. R. Greenhalgh, J. D. Law, R. Jubin, D. M. Strachan, and P. K. Thallapally, 2013, "Radioactive Iodine and Krypton Control for Nuclear Fuel Reprocessing Facilities," Hindawi Publishing Corporation, Science and Technology of Nuclear Installations, Volume 2013, Article ID 702496, 12 pages, INL/JOU-13-28481, Feb. 19, 2013, http://dx.doi.org/10.1155/2013/702496.

Soelberg, N., 2013, "Recent Deep-Bed Test Results for Capturing I-129 in Used Fuel Reprocessing Offgas Streams," Global 2013, October 3.

Soelberg, N. and T. Watson, 2014, "Phase 2 Methyl Iodide Deep-Bed Adsorption Tests," FCRD-SWF2014-000273, INL/EXT-14-33269, September 30.

Soelberg, N. and T. Watson, 2015, "FY-2015 Methyl Iodide Deep-Bed Adsorption Test Report," FCRDMRWFD-2015-000267, INL/EXT-15-36817, Idaho National Laboratory, September 30.

Soelberg, N., 2016, “Deep-Bed Iodine Adsorption Test Results,” INL/MIS-16-38237, MRWFD Campaign Working Group Meeting, PNNL, Richland, WA, March 22-23.

Soelberg, N. and T. Watson, 2016, "FY-2016 Methyl Iodide Higher NOx Adsorption Test Report," FCRD-MRWFD-2016-000352, INL/EXT-16-40087, Idaho National Laboratory, September 29.

Welty, A.K., Garn, Troy G., and Greenhalgh, Mitchell, "Superficial Velocity Effects on HZ-PAN and AgZ-PAN for Kr/Xe Capture, Idaho National Laboratory, April 1, 2016, FCRD-MRWD-2016-000024 